\title{
PENGANTAR
}
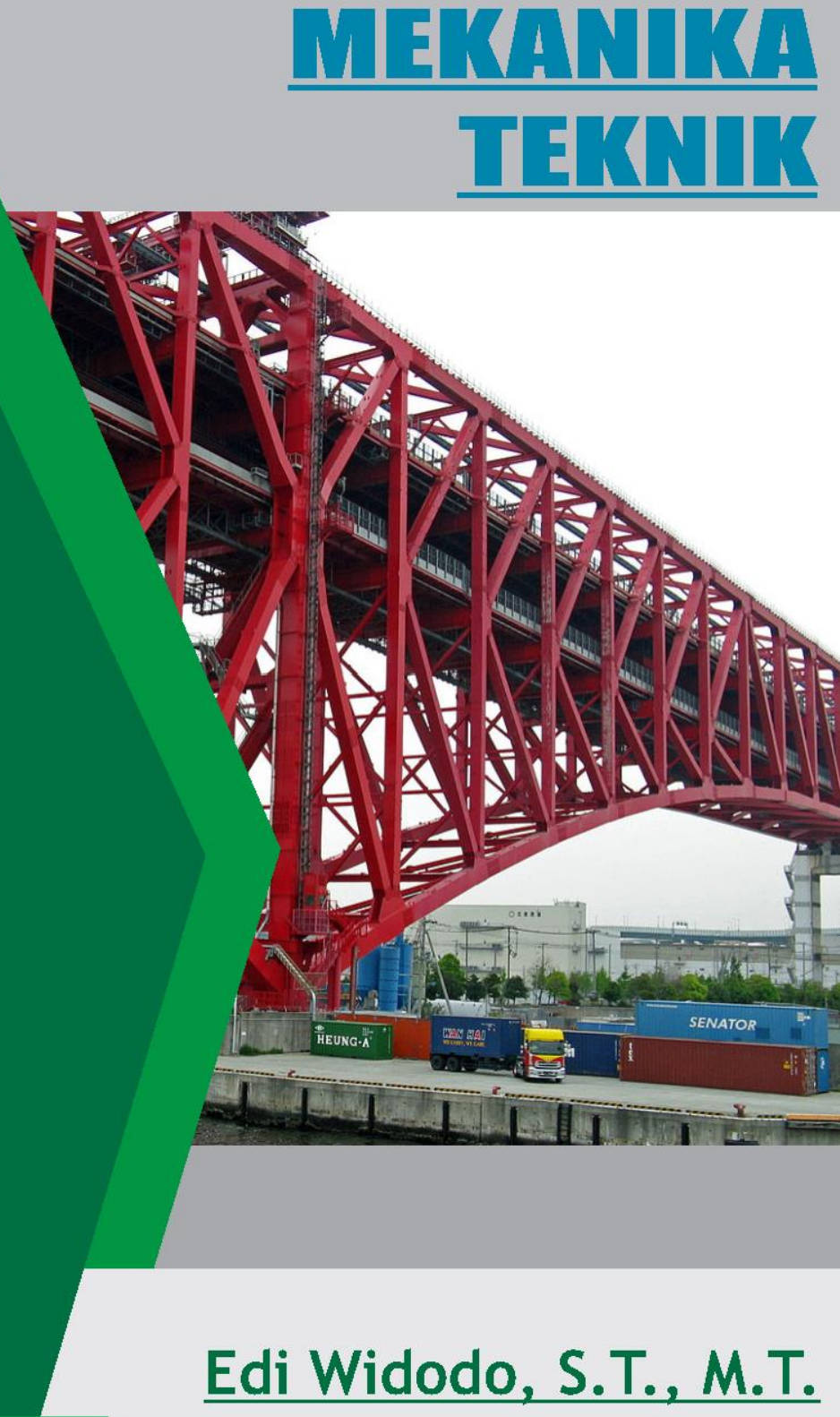


\section{BUKU AJAR \\ PENGANTAR MEKANIKA TEKNIK}

Disusun oleh:

Edi Widodo,S.T., M.T.

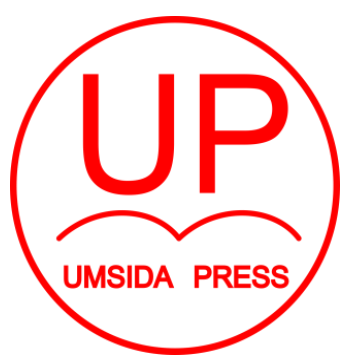

Diterbitkan oleh

\section{UMSIDA PRESS}

Jl. Mojopahit 666 B Sidoarjo

ISBN: 978-602-5914-44-7

Copyright $(2018$.

\section{Authors}

All rights reserved 


\section{BUKU AJAR}

\section{PENGANTAR MEKANIKA TEKNIK}

\section{Penulis :}

Edi Widodo,S.T., M.T.

\section{ISBN :}

978-602-5914-44-7

\section{Editor :}

Septi Budi Sartika, M.Pd

M. Tanzil Multazam, S.H., M.Kn.

Copy Editor :

Fika Megawati, S.Pd., M.Pd.

Design Sampul dan Tata Letak :

Mochamad Nashrullah, S.Pd

Penerbit :

UMSIDA Press

Redaksi :

Universitas Muhammadiyah Sidoarjo

Jl. Mojopahit No 666B

Sidoarjo, Jawa TImur

Cetakan pertama, Agustus 2018

(C) Hak cipta dilindungi undang-undang

Dilarang memperbanyak karya tulis ini dengan suatu apapun

tanpa ijin tertulis dari penerbit. 


\section{Kata Pengantar}

Alhamdulillah, segala puji kehadirat Allah atas limpahan rahmat dan hidayahNya, buku pegangan Mekanika teknik ini dapat diselesaikan. Ucapan terimakasih kepada Universitas Muhamamdiyah Sidoarjo, melalui LP3iK yang telah memfasilitasi terlaksananya program penulisan buku ajar pendamping mata kuliah. Penulis berharap buku ini dapat menjadi pelengkap bagi mahasiswa maupun tenaga pengajar/ dosen dalam pembelajaran mekanika. Buku ini berisi penjelasan singkat tentang bab - bab terpilih untuk memberikan pemahaman basic sehingga diharapkan dapat dikembangkan lebih dalam dengan melakukan studi yang lebih terkonsentrasi. Penulis menyusun buku ini dari hasil studi dari berbagai referensi, yang dirangkum dan disajikan dengan lebih sederhana. Harapannya dapat dijadikan sebagai buku pendamping dan pelengkap untuk referensi yang lebih lengkap dan komprehensif. Saran dan kritik sangat kami harapkan sebagai bentuk koreksi dan perbaikan untuk penerbitan berikutnya. 


\section{Daftar Isi}

Kata Pengantar ii

Daftar Isi ..............................................................................

Daftar Gambar ............................................................... vii

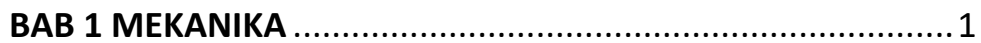

1.1. Pengantar Mekanika .............................................. 1

1.2. Pengertian Mekanika Teknik ............................... 5

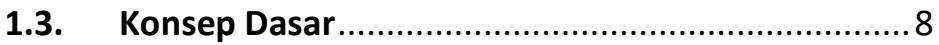

1.4. Sistem Tumpuan............................................ 11

2.1. Gaya Dan Resultan Dari Dua Gaya ..................... 17

2.2. Metode Penyelesaian Resultan Vektor................ 20

2.2.1. Penjumlahan Vektor.................................... 20

BAB 3 KESEIMBANGAN PARTIKEL ............................... 30

BAB IV TITIK PUSAT MASSA DARI MATERIAL DUA DIMENSI 32 BAB V TITIK PUSAT MASSA DALAM BENDA TIGA DIMENSI . 43

5.1. Analisis teoritik.............................................. 43

5.2. Titik Pusat Massa Dalam Numerik ...................... 46 BAB VI STRUKTUR BEBAN TERPUSAT DAN BEBAN TERDISTRIBUSI ........................................................ 55

6.1. Analisa Beban Terpusat........................................55

6.2. Analisa Gaya Geser.......................................... 57

6.3. Analisa Gaya Lintang/Momen............................59

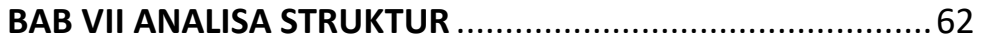




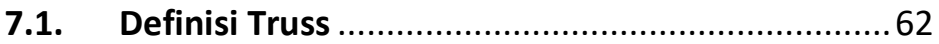

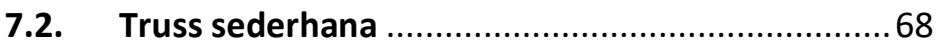

7.3. Analisa truss dengan metode join.......................... 72

7.4. Analisa Truss Dengan Metode Section ....................8 80

7.5. Truss komplek ..................................................... 84

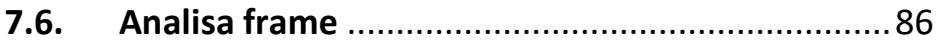

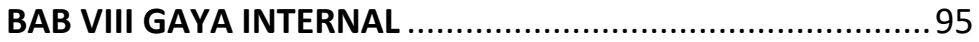

8.1. Gaya ...................................................................95

8.2. Jenis-Jenis Beban dan Tumpuan .............................99

8.3. Gaya Geser dan Momen Bending Pada Beam ....103

8.4. Diagram Gaya Geser dan Momen Lentur ...........111

8.5. Beban Kabel dengan Beban Terpusat ..................117

DAFTAR PUSTAKA ……..................................................122 


\section{Daftar Gambar}

Gambar 1. 1 Pembebanan pada jembatan 6

Gambar 1. 2 pembebanan pada batang dengan dua tumpuan

Gambar 1. 3 Tumpuan Roll ............................................. 12

Gambar 1. 4 Tumpuan Sendi ............................................ 12

Gambar 1. 5 Tumpuan Jepit.............................................. 13

Gambar 1. 6 Beban Terpusat .......................................... 14

Gambar 1. 7 Beban Terdistribusi ........................................ 14

Gambar 1. 8 Beban Momen................................................ 15

Gambar 2. 1 Resultan vektor metode segitiga..................... 21

Gambar 2. 2 Penjumlahan vektor ..................................... 22

Gambar 2. 3 Resultan vektor dengan metode polygon ......... 23

Gambar 2. 4 Resultan 3 buah vektor ................................. 24

Gambar 2. 5 Resultan 5 vektor .......................................... 24

Gambar 4. 1 Penampang bidang bersusun .......................... 35

Gambar 4. 2 Penguraian bentuk penampang ....................... 36

Gambar 4. 3 Penentuan titik x1 x2 y1 y2 ........................... 36

Gambar 4. 4 Membuat bentuk lain penampang .................... 37

Gambar 4. 5 Bentuk lain penampang 2.............................. 38

Gambar 4. 6 Menentukan titik X1, X2, Y1, Y2 ..................... 38

Gambar 4. 7 Penampang lingkaran berlubang...................... 39

Gambar 4. 8 Menguraikan penampang ................................ 40

Gambar 4. 9 Menentukan titik X1, X2, Y1, Y2 ..................... 40

Gambar 4. 10 Penentuan titik pusat massa ......................... 42 
Gambar 6. 1 Gambar Beban pada balok ............................. 55

Gambar 6.2 balok dengan dua tumpuan ............................ 56

Gambar 6. 3 Balok dua tumpuan ....................................... 56

Gambar 6. 4 Hasil perhitungan reaksi balok bertumpuan .....57

Gambar 6. 5 Balok dengan tumpuan tunggal .......................58

Gambar 6. 6 Balok tumpuan dengan beban tunggal ............. 58

Gambar 6. 7 Diagram gaya geser balok tumpuan ..................59

Gambar 6. 8 Potongan 1 ............................................... 59

Gambar 6. 9 Potongan 2 ...................................................... 60

Gambar 6. 10 Diagram Momen batang dua tumpuan ............ 61

Gambar 6. 11 Diagram geser dan momen .......................... 61

Gambar 7. 1 Batang dengan tumpuan rol dan tumpuan pin .63 Gambar 7. 2 A. Sistem rangka 1 ........................................ 64

Gambar 7. 3 B. Sistem rangka 2 ...................................... 64

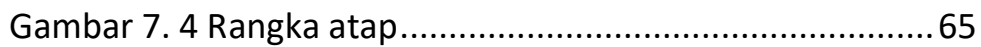

Gambar 7. 5 Rangka jembatan......................................... 65

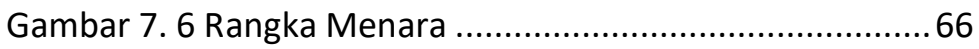

Gambar 7. 7 Beberapa contoh struktur ...............................67

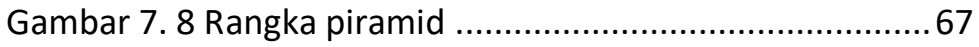

Gambar 7. 9 Struktur Portal ruang.....................................6 68

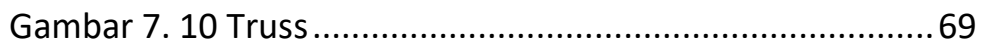

Gambar 7. 11 Trus sederhana .............................................. 70

Gambar 7. 12 gaya-gaya pada titik A ................................. 70

Gambar 7. 13 Gaya pada titik B ....................................... 71

Gambar 7. 14 Gaya pada titik C .......................................... 72

Gambar 7. 15 latihan penyelesain truss............................... 74

Gambar 7. 16 Gaya pada buhul A ................................... 77

Gambar 7. 17 Digram gaya ........................................... 78 
Gambar 7. 18 Gaya buhul C ............................................. 79

Gambar 7. 19 Potongan 1-1............................................. 82

Gambar 7. 20 Potongan 2-2 ............................................... 82

Gambar 7. 21 Truss jembatan............................................ 84

Gambar 7. 22 Perbandingan sistem struktur rangka batang dengan dinding geser. ..................................................... 86

Gambar 7. 23 Tipe penampang profil baja ............................ 89

Gambar 7. 24 Idealisasi sistem rangka batang .......................90

Gambar 7. 25 Sistem staggered truss diibaratkan sebagai

kantilever vertikal (Scalzi, 1971) ......................................... 92

Gambar 7. 26 Pola bergantian truss pada sistem struktur.....93

Gambar 8. 1 Pembangkitan Gaya ...................................... 95

Gambar 8. 2 Unsur-unsur gaya (Sumber: Husin, 1989).......... 95

Gambar 8. 3 Garis kerja gaya .......................................... 96

Gambar 8. 4 Arah reaksi pada balok 2 tumpuan................... 98

Gambar 8. 5 Beban terdistribusi ........................................ 99

Gambar 8. 6 Beban terpusat/segitiga ...............................100

Gambar 8. 7 Titik berat massa beban segitiga .................... 100

Gambar 8. 8 Sendi engsel ................................................ 101

Gambar 8. 9 Jenis tumpuan rol ........................................ 102

Gambar 8. 10 Jenis tumpuan Jepit...................................103

Gambar 8. 11 Beban Transversal pada Balok......................104

Gambar 8. 12 Diagram Benda Bebas ..................................105

Gambar 8. 13 Tanda Gaya Geser (Zainuri,2008) ..................105

Gambar 8. 14 Definisi Momen Lentur (Zainuri,2008) ..........106

Gambar 8. 15 Tanda Momen Lentur (Zainuri,2008) ............106

Gambar 8. 16 Gaya dan Momen pada Balok . (Titherington,

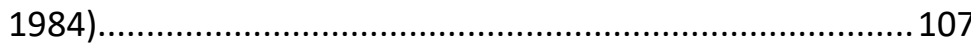

Gambar 8. 17 Distribusi Tegangan Geser (Hibbeler, 2004) ..109 
Gambar 8. 18 Lenturan pada Balok (www.transtutors.com) 111 Gambar 8. 19 Distribusi Tegangan Akibat Lentur................111 Gambar 8. 20 Pembuatan Diagram Gaya Geser dan Momen Lentur (Beer,1996)

Gambar 8. 21 Diagram Gaya Geser dan Momen Lentur

Kantilever (Titherington,1984) 115

Gambar 8. 22 Diagram Gaya Geser dan Momen Lentur Simple Beam (Titherington,1984) 116

Gambar 8. 23 Kabel Dengan Beban Terkonsentrasi.............117

Gambar 8. 24 Diagram Benda Bebas Sub-Bagian Kabel .......119

Gambar 8. 25 Gaya terdistribusi pada kabel ......................120

Gambar 8. 26 Model Kabel Katenari................................. 121 


\section{BAB 1 MEKANIKA}

\subsection{Pengantar Mekanika}

Mekanika Teknik merupakan mata kuliah yang menempati porsi dominan. Semua jenis bangunan di darat, laut bahkan di angkasa luar pasti melalui serangkaian analisis struktur sehingga perencana mendapatkan suatu keyakinan bahwa sistem struktur yang akan dibangun berada dalam kondisi kuat, kokoh, aman, dan awet baik selama masa pelaksanaan konstruksi atau selama umur bangunan tersebut.

Prinsip-prinsip dasar Mekanika Teknik, sebenarnya bersumber dari hasil kerja Isaac Newton (1642 - 1727). Dalam mekanika klasik, Newton berhasil menyusun 3 (tiga) pokok hukum tentang gerak benda.

Hukum I,

$\sum \mathbf{F}=m \mathbf{a}$

Hukum ini menyebutkan, jika resultan vektor gaya-gaya yang bekerja pada suatu sistem sama dengan nol, maka benda tersebut dalam keadaan diam (atau bergerak lurus beraturan).

Hukum II,

\section{$\sum \mathbf{F}=m \mathbf{a}$}

Dalam bahasa sehari-hari kita artikan, jika vektor resultan gayagaya yang diterima oleh suatu sistem tidak sama dengan nol, maka sistem yang massa totalnya $\mathrm{m}$ akan mengalami gerak lurus dipercepat (atau diperlambat) sebesar vektor â Harap diingat, vektor adalah besaran yang memiliki besar(nilai) dan 
arah. Sehingga kondisi sistem dipercepat atau diperlambat bisa dilihat dari vektornya.

Hukum III,

$\mathbf{F}_{a k s i}=-\mathbf{F}_{\text {reaksi }}$

Ini dikenal dengan istilah hukum timbal balik, jika suatu vektor gaya $F$ bekerja pada suatu sistem, maka sistem akan memberikan gaya reaksinya dengan besar yang sama dengan besar gaya aksi tetapi dalam arah yang berlawanan.

Dalam analisis struktur statik, kita selalu berpedoman pada hukum I dan III meskipun dalam perkembangannya vektor gaya $\mathbf{F}$ dan vektor perpindahan $\mathbf{d}$ merupakan matriks vektor yang dinyatakan dalam :

Dalam hal ini

$$
\mathbf{F}=\left\{\begin{array}{c}
F_{x} \\
F_{y} \\
F_{z} \\
M_{x} \\
M_{y} \\
M_{z}
\end{array}\right\}
$$

$$
\mathbf{d}=\left\{\begin{array}{c}
\Delta_{x} \\
\Delta_{y} \\
\Delta_{z} \\
\theta_{x} \\
\theta_{y} \\
\theta_{z}
\end{array}\right\}
$$

$F$, adalah gaya (dapat berupa gaya aksial atau gaya geser) $M$, adalah momen gaya (dapat berupa momen lentur, momen torsi)
$\Delta$ adalah defleksi
$\Theta$ adalah putaran sudut dalam arah sumbu 
Sehingga Hukum Newton I diterapkan dalam bidang Teknik sebagai:

$\sum\left\{\begin{array}{l}\mathbf{F} \\ \mathbf{d}\end{array}\right\}=0$

artinya "Jika sistem berada dalam keadaan setimbang, maka haruslah dipenuhi persyaratan mekanis sebagai jumlah semua matriks vektor gaya sama dengan nol dan jumlah semua matriks vektor perpindahan sama dengan nol"

Inilah yang merupakan prinsip dasar dari analisis struktur statik yang dalam aplikasinya menggunakan matematika terapan untuk menterjemahkan prinsip dasar diatas secara kualitatif.

Sebelum membahas hukum Newton yang kedua, ada baiknya kalau saya sampaikan kalo analisis struktur itu terbagi menjadi dua bagian yaitu :

\section{A. Analisis struktur statik}

Vektor gaya-gaya yang bekerja pada analisis struktur statik bukan merupakan fungsi dari waktu, jadi besar dan arah vektor gaya yang bekerja pada sistem selalu statis. Kajian analisis struktur statik didasarkan pada Hukum Newton pertama dan ketiga (sebagian kecil sudah saya singgung di atas). Contoh analisis struktur statis misalnya : beban akibat struktur itu sendiri, beban suhu pada struktur jembatan, beban tanah pada fondasi dan lain-lain.

\section{B. Analisis struktur dinamik}

Pada analisis dinamik, bidang kajian semakin dalam. Vektor gaya yang diterima sistem struktur merupakan fungsi dari waktu, jadi baik arah dan besarnya bisa berubah setiap saat. Karena itu untuk analisis struktur dinamik ini diperlukan 
penelaahan secara mendalam, mungkin suatu saat akan saya kupas habis bagian mekanika teknik yang sangat menarik ini. Ada banyak contoh yang berkaitan dengan analisis struktur dinamik ini, misalnya analisis getaran pada badan pesawat terbang, analisis respon dinamik pada gedung atau jembatan bentang panjang, pemodelan aeroelastik serta aerodinamik pada pengujian terowongan angin dan lain-lain. Prinsip utamanya didasarkan pada hukum Newton yang kedua,

\section{$\sum \mathbf{F}=m \mathbf{a}$}

seperti kita ketahui, vektor percepatan merupakan perubahan vektor kecepatan setiap saatnya, jadi didefinisikan :

$\mathbf{v}=\frac{d \mathbf{r}}{d t}$

$\mathbf{a}=\frac{d \mathbf{v}}{d t}$

$\mathbf{a}=\frac{d \frac{d \mathbf{r}}{d t}}{d t}$

$\mathbf{a}=\frac{d^{2} \mathbf{r}}{d t^{2}}$

Sehingga hukum Newton kedua menjadi,

$\sum \mathbf{F}=m \mathbf{a}$

$\sum \mathbf{F}=m \frac{d^{2} \mathbf{r}}{d t^{2}}$

Vektor gaya elastisitas struktur yang memiliki kekakuan $\mathbf{K}$ memenuhi hukum Hooke,

$\mathbf{F}_{e}=-k \mathbf{r}$ 
Sehingga jika sistem struktur secara keseluruhan menerima vektor gaya luar $\mathbf{F}$ maka resultan vektor gayanya adalah

$$
\begin{aligned}
& \sum \mathbf{F}=m \frac{d^{2} \mathbf{r}}{d t^{2}} \\
& \mathbf{F}_{r}+\mathbf{F}_{e}+\mathbf{F}(t)=m \frac{d^{2} \mathbf{r}}{d t^{2}} \\
& -c \frac{d \mathbf{r}}{d t}-k \mathbf{r}+\mathbf{F}(t)=m \frac{d^{2} \mathbf{r}}{d t^{2}} \\
& m \frac{d^{2} \mathbf{r}}{d t^{2}}+c \frac{d \mathbf{r}}{d t}+k \mathbf{r}=\mathbf{F}(t)
\end{aligned}
$$

persamaan terakhir ini adalah persamaan umum gerak dinamik partikel sebagai fungsi dari waktu. Analisis lebih lanjut diberikan dalam pembahasan persamaan diferensial biasa orde kedua (bisa dibaca sendiri di banyak literatur matematika rekayasa atau matematika terapan) Untuk sementara, pada saat ini dibatasi untuk analisis struktur statik pada kondisi linear elastik.

\subsection{Pengertian Mekanika Teknik}

Mekanika Teknik adalah cabang dari ilmu fisika yang mempelajari keadaan status benda baik dalam keadaan diam atau bergerak akibat pengaruh gaya - gaya yang bekerja ilmu ini sangat penting perannya dalam sistem analisis kerekayasaan dan seringkali orang menyebut bahwa awal dari rekayasa adalah mekanika. Ilmu mekanika tergolong ilmu fisika yang paling tua dibandingkan ilmu-ilmu fisika yang lain. Sedangkan mekanika Teknik adalah ilmu yang sangat mendasar mempelajari hal penting yang diperlukan dalam mendesain 
dan merancang mulai dari alat atau mesin transportasi bangunan perlengkapan sampai furniture.

Ilustrasi gaya yang bekerja pada sebuah jembatan dari kendaraan yang lewat dapat dilihat pada gambar 1.1.

Contoh :

- Suatu kendaraan yang diatas jembatan.

- Benda roda kendaraan pada jembatan tersebut adalah suatu beban atau gaya.

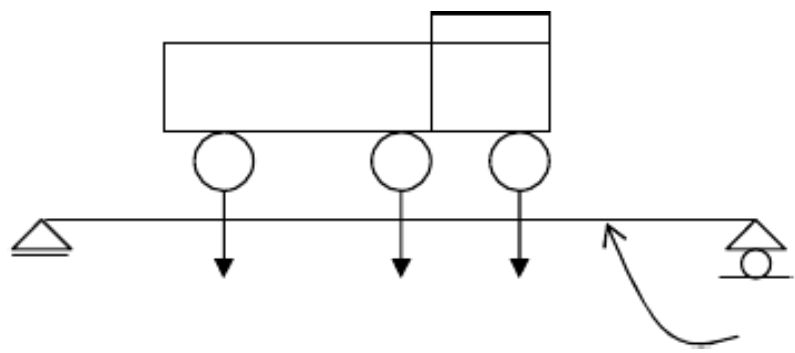

Gambar 1. 1 Pembebanan pada jembatan

\section{Pengertian tentang Gaya dan Garis Kerja gaya:}

Gaya adalah merupakan vektor yang mempunyai besar dan arah. Penggambarannya biasanya berupa garis dengan panjang sesuai dengan skala yang ditentukan. Jadi panjang garis bisa dikonversikan dengan besarnya gaya.

MEKANIKA dibagi menjadi 3 yaitu:

A. Mekanika Benda-Benda Kaku di bagi lagi menjadi dua:

1. Statika

Statika adalah ilmu tentang keseimbangan, antara lain berhubungan dengan perubahan gaya-gaya yang tidak diketahui yang bekerja pada benda pengetahuan mengenai 
gaya-gaya ini adalah sangat penting untuk perhitungan perhitungan stabilitas.

2. Dinamika

Dinamika adalah suatu bentuk perubahan, baik itu yang sifat nya besar-besaran atau kecil-kecilan, maupun secara cepat atau lambat, yang sifat nya nyata dan berhubungan dengan suatu kondisi keadaan.

\section{B. Mekanika Benda-Benda Elastis}

Elastisitas adalah kemampuan benda padat yang jika di beri tegangan yang sebagian maka benda tersebut dapat kembali seperti semula.

\section{Hukum-Hukum Elastisitas}

\section{Hukum tetapan gaya}

tetapan gaya atau tetapan elastis adalah ketetapan elastisitas bagi sebuah benda. Bila pada bentuk dan ukuran tidak memperanguhi, maka pada tetapan gaya hal tersebut mempengaruhi. Karena tetapan gaya dirumuskan sebagai berikut :

$$
\begin{aligned}
& \boldsymbol{k}=\mathbf{A} \cdot \mathbf{E} / \mathrm{L} \\
& \mathrm{k}=\text { tetapan gaya }(\mathrm{N} / \mathrm{m}) \\
& \mathrm{A}=\text { luas penampang }(\mathrm{m} 2) \\
& \mathrm{E}=\text { Modulus elastis }(\mathrm{N} / \mathrm{m} 2 \text { atau } \mathrm{Pa}) \\
& \mathrm{L}=\text { Panjang mula-mula }(\mathrm{m})
\end{aligned}
$$

\section{Hukum Hooke}

hukum hooke grafik tegangan-regangan diatas, sebelum batas hukum hooke, tegangan dan regangan sebanding, besarnya dipengaruhi oleh tetapan gaya, karena itu hukum hooke dirumuskan dalam: 
$F=\mathbf{k} \cdot \Delta \mathrm{L}$

$\mathrm{F}=$ Gaya $(\mathrm{N})$

$\mathrm{k}$ = tetapan gaya atau tetapan pegas $(\mathrm{N} / \mathrm{m})$

$\Delta \mathrm{L}=$ Pertambahan Panjang $(\mathrm{m})$

\subsection{Konsep Dasar}

Konsep dasar mekanika pemahaman tetang benda diam pada statika disebut struktur. Struktur yang dianalisa oleh ilmu statika dibagi menjadi Dua bagian umum yaitu: struktur statis tertentu dan struktur statis tak tentu.

A. Struktur statis tertentu adalah struktur yang tidak memiliki kendala yang lebih dari yang diperlukan untuk mempertahankan kesetimbangan. Pada analisa struktur tersebut hanya menggunakan persamaan kesetimbangan, cukup untuk menentukan semua reaksi yang tak diketahui yaitu :

$\mathrm{F}=0, \mathrm{M}=0$, diagram benda bebas, arah gaya momen merupakan tahapan terpenting dalam penyelesaian persoalan statika.

Bila arah gaya beban ke atas diberi tanda positif (+) dan sebalik nya (-) bila arah momen searah jarum jam diberi tanda positif (+) maka sebalik nya (-).

Konsep dasar dari statika adalah kesetimbangan gaya-gaya yang bekerja pada suatu struktur, artinya semua gaya-gaya yang bekerja pada suatu struktur adalah dalam keadaan setimbang, baik struktur itu ditinjau secara keseluruhan maupun sebagian. Pada hukum newton ketiga, yaitu ada aksi maka akan diimbangi oleh reaksi. Artinya jumlah gaya-gaya yang bekerja adalah nol. 


\section{Gaya (F)}

Gaya adalah sebuah besaran vektor, yang secara umum artinya sebuah besaran yang tidak hanya bergantung pada besarnya saja, tapi juga arahnya. Gaya yang bekerja pada benda kaku berdasar pada tumpuannya. Jadi gaya mempunyai tiga karakteristik, yaitu besarnya, arahnya dan juga titik/lokasi bekerjanya yang biasanya direpresentasikan garis bertanda panah, artinya jika satu atau lebih dari tiga karakteristik ini dirubah, maka efeknya terhadap objek yang dikenakan gaya tersebut akan berubah. Besarnya gaya jelas pengaruhnya, sebagai contoh, kalau kita berusaha mendorong mobil yang relative besar sendirian, kemungkinan besar mobil tidak bergerak karena gaya yang kita berikan ke mobil tidak cukup besar, tetapi jika kita minta bantuan dua orang lagi untuk membantu mendorong mobil, maka besar kemungkinan mobil bisa didorong oleh tiga orang tersebut karena gaya yang ditimbulkan oleh ketiga orang tersebut lebih besar dibandingkan dengan gaya yang dihasilkan oleh satu orang. Contoh rumus gaya searah dan gaya yang berlawanan :

a. Jika gaya-gayanya searah:

$$
R=F_{1}+F_{2}
$$

b. Jika gaya-gayanya berlawanan arah:

$$
R=F_{1}-F_{2}
$$

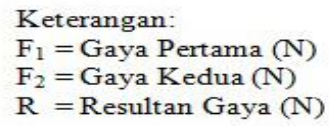

Keterangan:

$\mathrm{F}_{1}=$ Gaya Pertama $(\mathrm{N})$

$\mathrm{F}_{2}=$ Gaya Kedua (N)

$\mathrm{R}=$ Resultan Gaya $(\mathrm{N})$

\section{Momen (M)}

Momen merupakan gaya dikali jarak. Momen terjadi akibat bekerjanya gaya-gaya pada suatu balok yang mengakibatkan balok tersebut akan melentur dengan demikian serat bagian terluar akan mengalami tarikan dan serat bagian dalam akan mengalami perpendekan ( tekanan ). Gejala yang terlihat pada serat terluar akan mengalami retak-retak bila kemampuan 
balok melebihi dari tahanan balok tersebut, bahkan yang lebih fatal balok bisa patah.

Pada beton bertulang dimana bahan yang dipakai adalah beton dan besi tulangan, beton hanya kuat menahan desakan atau gaya tekan sedangkan untuk tarikan ini adalah merupakan tugas dari besi tulangan. Dengan demikian pada serat terluar ( daerah tarikan ) perlu diberikan tulangan pokok untuk menjaga agar balok tersebut dapat menahan kombinasi pembebanan yang bekerja padanya. Contoh soal momen :

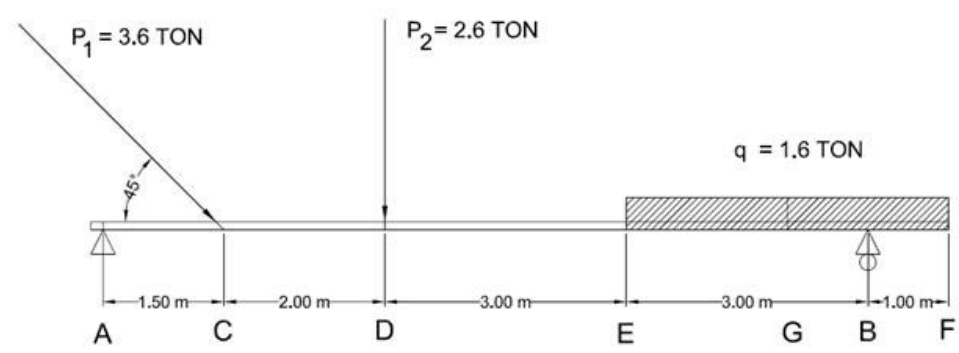

Gambar 1. 2 pembebanan pada batang dengan dua tumpuan

\section{Diagram Benda Bebas (DBB)}

Diagram Benda Bebas (Free Body Diagram) Diagram yang menggambarkan semua gaya-gaya yang bekerja pada suatu partikel dalam keadaan bebas. Dalam menganalisis persoalan mekanika diagram benda bebas ini sangat diperlukan untuk membantu memahami dan menggambarkan masalah kesetimbangan gaya dari suatu partikel.

\section{KONSEP KESEIMBANGAN}


a. Suatu partikel dalam keadaan keseimbangan jika resultan semua gaya yangbekerja pada partikel tersebut nol.

b. Jika pada suatu partikel diberi 2 gaya yang sama besar, mempunyai garis gayayang sama dan arah berlawanan, maka resultan gaya tersebut adalah NOL. Haltersebut menunjukkan partikel dalam keseimbangan.

c. Sebuah benda tegar dikatakan dalam keseimbangan jika gaya-gaya yangbereaksi pada benda tersebut membentuk gaya / sistem gaya ekvivalen dengannol.

d. Sistem tidak mempunyai resultan gaya dan resultan kope I.

e. Syarat perlu dan cukup untuk keseimbangan suatu benda tegar secara analitisadalah :

(i) jumlah gaya arah $\mathrm{x}=0\left(\sum \mathrm{Fx}=0\right)$

(ii) jumlah gaya arah $\mathrm{y}=0\left(\sum \mathrm{Fy}=0\right)$

(iii) jumlah momen $=0\left(\sum M=0\right)$

f. Dari persamaan tersebut dapat dikatakan bahwa benda tidak bergerak dalamarah translasi atau arah rotasi (diam).

g. Jika ditinjau dari Hukum III Newton, maka keseimbangan terjadi jika gaya aksimendapat reaksi yang besarnya sama dengan gaya aksi tetapi arahnya saling berlawanan.

\subsection{Sistem Tumpuan}

1. Tumpuan Roll

Ciri khas dari tumpuan roll :

a. Dapat memberikan reaksi berupa gayavertikal $(\mathrm{Ry}=$ Fy)

b. Tidak dapat menerima gaya horisontal(Fx).

c. Tidak dapat menerima momen 
d. Jika

diberi gaya horisontal, akanbergerak/menggelinding karena Sifat Roll.

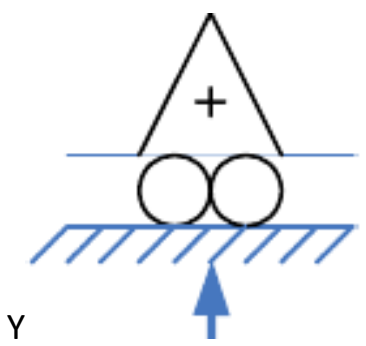

Gambar 1. 3 Tumpuan Roll

2. Tumpuan Sendi

a. Mampu Menerima 2 Reaksi Gaya :A) Gaya Vertikal (Fy)B) Gaya Horisontal (Fx)

b. Tidak Dapat Menerima Momen (M).

c. Jika Diberi Beban Momen, Karena Sifatsendi, Maka Akan Berputar.

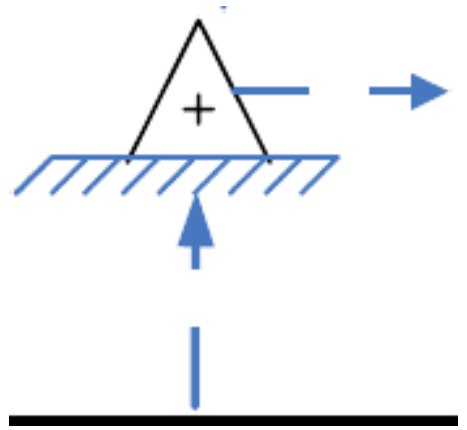

Gambar 1. 4 Tumpuan Sendi 
3. Tumpuan Jepit

a. Dapat Menerima Semua Reaksi:A) Gaya Vertikal ( y)B) Gaya Horizontal (Fx)C) Momen (M)

b. Dijepit Berarti Dianggap Tidak Ada gerakan Sama Sekali.

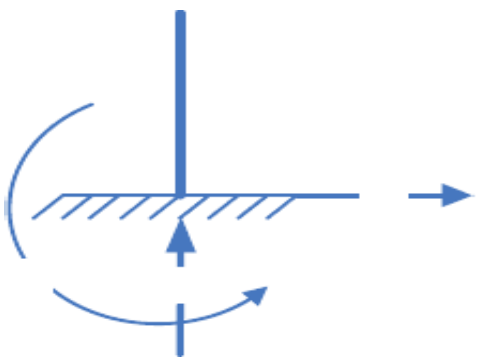

Gambar 1. 5 Tumpuan Jepit

\section{Beban (Muatan)}

Merupakan Aksi / Gaya /Beban Yang Mengenai Struktur. Beban Dapat Dibedakanmenjadi Beberapa Jenis Berdasarkan Cara Bekerja Dari Beban Tersebut.

1. Beban Titik/Beban Terpusat.Beban Yang Mengenai Struktur Hanya Pada Satu Titik Tertentu Secara Terpusat. 

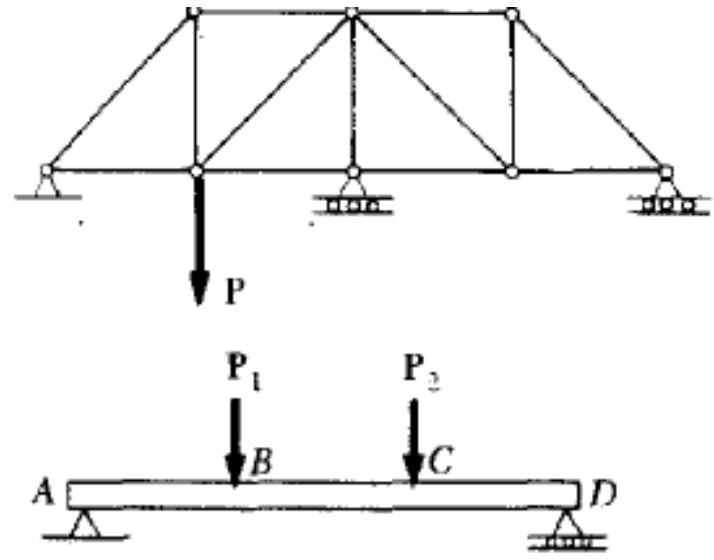

Gambar 1. 6 Beban Terpusat

2. Beban Terdistribusi Merata.Beban Yang Mengenai Struktur Tidak Terpusat Tetapi Terdistribusi, Baik Terdistribusimerata Ataupun Tidak Merata. Sebagai Contoh Beban Angin, Air Dan Tekanan.

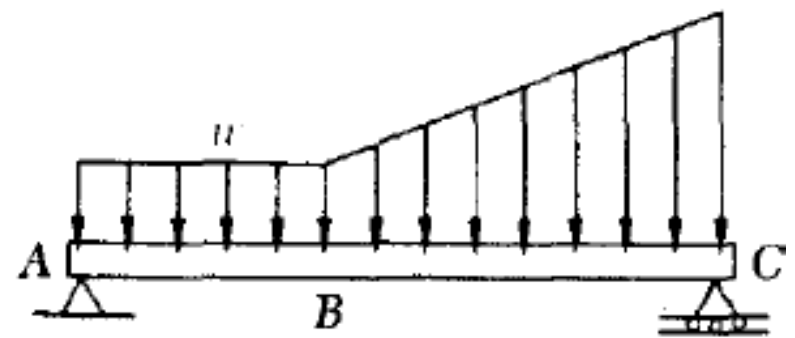

Gambar 1. 7 Beban Terdistribusi

3. Beban momen, Beban momen dapat berupa adanya beban titik pada konstruksi menimbulkanmomen atau momen yang memang diterima oleh konstruksi seperti momen puntir(torsi) pada poros transmisi. 


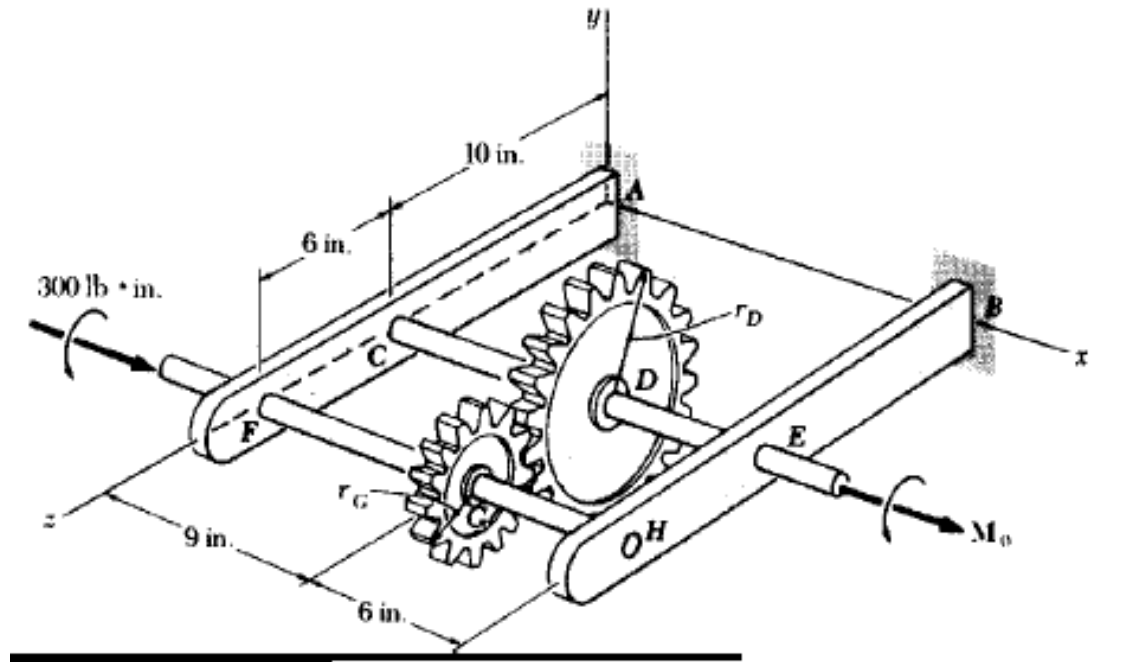

Gambar 1. 8 Beban Momen

a. Dalam konstruksi mekanika teknik

yang sesungguhnya, beban yang dialami olehstruktur merupakan beban gabungan.Misalnya sebuah jembatan dapat mengalami beban titik, beban bergerak, bebanterbagi merata, beban angin dll.

b. Semua beban harus dihitung dan menjadi ko mponen AKSI, yang akan diteruskanke tumpuan/peletakan, dimana tumpuan akan memberikan REAKSI Sebesar aksi yang diterima, sehingga terpenuhi : AKSI/REAKSI

c. Fokus dalam

Mekanika Teknik I (Statika Struktur) adalah: Statis Tertentu. Bahwa persoalan yang dipelajari dapat diselesaikan hanya dengan menggunakan 3 
persamaan keseimbangan statik yaitu : $\Sigma \mathrm{Fx}=$ $0, \Sigma F y=0, \Sigma M=0$.

d. Jika persoalan tidak dapat diselesaikan dengan 3 persamaan tersebut dan membutuhkan lebih banyak persamaan, maka disebut dengan,

Kesetabilan konstruksi statis tertentu diperole h jika :

e. Semua gejala gerakan (gaya) mengakibatkan perlawanan (reaksi) terhadapgerakan tersebut, suatu konstruksi statis tertentu akan stabil jika reaksi-reaksinya dapat dihitungdengan persamaan statis terte ntu

f. Dalam menganalisis suatu persoalan mekanika teknik, biasanya digunakan beberapa diagram yang dapat mendukung kemudahan analisis tersebut. 


\section{BAB II STATIKA}

Statika adalah ilmu yang mempelajari keseimbangan gaya dengan gaya-gaya tersebut dalam keadaan diam, jadi bisa di bilang statika itu kesetimbangan suatu struktur.

Statika adalah salah satu cabang dari mekanika teknik yang berhubungan dengan analisis gaya-gaya yang bekerja pada sistem struktur yang dalam keadaan diam/statis dan setimbang. Gaya-gaya yang dimaksud disini pada umumnya termasuk gaya itu sendiri dan juga momen. Di dalam statika, sistem struktur diidealisasikan/dianggap sangat kaku sehingga pengaruh dari ledutan tidak diperhatikan. Dan struktur itu sendiri adalah gabungan dari kompnen-komponen yang menahan gaya desak dan atau tarik, mungkin juga momen untuk meneruskan beban-beban dengan aman (seimbang).

Ilmu statika umumnya merupakan salah mata kuliah bidang teknik pertama yang diberikan di level universitas. Prinsip-prinsip yang dipelajari dalam statika cukup mendasar dan mudah dipahami, hanya memerlukan sedikit dari hukumhukum fisika mekanika dan matematika dasar.

\subsection{Gaya Dan Resultan Dari Dua Gaya}

Gaya adalah suatu kekkuatan dapat berupa tarikan ataupun dorongan pada benda tersebut. Dengan adanya suatu gaya maka suatu benda dapat mengalami perubahan posisi atau bergerak maupun dapat berubah wujud (bentuk). Cntoh gaya ada pada suatu kegiatan permainan tarik tambang yang dapat merubah pelakunya untuk berpindah tempat. Maka gaya yang berupa tarikan atau dorongan memiliki arah gaya. Tarikan memiliki arah yang mendekt dan dorongan memiliki arah yang 
mendorongnya. Selain memiliki arah gaya, gaya juga memiliki nilai, maka gaya merupakan besaran vektor.

\section{Macam-Macam Gaya:}

1. Gaya Gesek

Gaya gesek adalah suatu gaya yang dapat terjadi karena ada bagian benda bergesekan dengan perumakaan yg datar. Gaya gesek sangat berguna untuk memperlamabat suatu gerakan benda. Gaya gesek juga dapat menimbulkan suara.

Contoh gaya gesek: Pada saat kita mengerem mobil, maka mobil tersebut dapat berhenti.

2. Gaya Gravitasi

Gaya gravitasi adalah suatu gaya yang dapat terjadi karena adanya gravitasi bumi. Gaya gravitasi mampu menyebabkna semua benda akan jatuh kebawah. Contoh :buah yang jatuh dari pohonnya.

3. Gaya otot

Gaya otot merupakan suatu gaya yang mennggunakan tenaga otot atau gaya yang dihasilkann oleh tarikan serta dorongan. Contoh : mendorong mobil yang mogok atau menarik suatu meja.

4. Gaya magnet

Gaya magnet adalah suatu gaya yg dapat ditimbulkan oleh suatu dorongan dan tarika dari sebuah magnet. Benda yang tidak dapat menempel pada magnet antara lain: kayu, aluminium, palstik, dst.

5. Gaya pegas

Gaya pegas adalah gaya yang dihasilkan dari pegas. Contoh gaya pegas: saat kita bernaim ketapel maka akan terjadi suatu gaya pegas, atau saat kita menekan per maka per itu akan menghasilkan suatu gaya pegas. 
6. Gaya listrik

Gaya listrik adalah suatu gaya yang dihasilkan oleh listrik. Contoh gaya listrik: saat kita menyalakan ssebuah lampu maka lampu itu akan menyala karena adanya suatu arus listrik atau gaya listrik.

\section{Rumus Gaya}

$\mathbf{F}=\mathbf{m} \mathbf{x} \mathbf{a}$

Keterangan :

$\mathrm{F}=$ Gaya ( $\mathrm{N}$ atau dyne)

$\mathrm{M}=$ Massa benda $(\mathrm{kg})$

$A=$ Percepatan $(\mathrm{m} / \mathrm{s})$

\section{Sifat Gaya}

1. Gaya berguna untuk mengubah posisi suatu benda hanya dengan mendorongnya atau menariknya.

2. Gaya dapat mengubah bentuk suatu benda.

3. Gaya dapat merubah arah suatu benda.

\section{Resultan Gaya}

Resultan gaya adalah suatu penjumlahan dari gaya gaya yang bekerja pada suatu benda tersebut. Resultan gaya berlambang huruf (R). Resultan gaya memiliki 2 jnis yang berbeda, yaitu:

1. Resultan gaya searah

Pada resultan gaya searah, gaya yang bekerja pada arah yang sama.

$$
R=\Sigma F=F_{1}+F_{2}
$$

2. Resultan gaya berlawanan arah 
Pada resultan gaya berlawanan arah, gaya yang bekerja dengan dua arah yang berbeda atau berlawanan.

$$
R=\Sigma F=F_{1}-F_{2}
$$

\subsection{Metode Penyelesaian Resultan Vektor}

Resultan vektor: adalah hasil penjumlahan atau pengurangan 2 vektor atau lebih. Resultan vector dapat diperoleh dari beberapa metode; yaitu metode segitiga, jajar genjang, polygon dan analisis.

\subsubsection{Penjumlahan Vektor}

Penjumlahan vektor adalah yaitu mencari sebuah vektor yang komponen - komponennya adalah jumlah dari kedua komponen - komponen vektor pembentuknya. Sebuah vektor yang terletak dalam bidang koordinat sumbu $\mathrm{x}$ dan sumbu y harus diuraikan menjadi komponen - komponen yang saling tegak lurus. Dan merupakan nilai efektif dalam suatu arah yang diberikan. Dengan kata lain "menjumlahkan dua buah" vektor adalah mencari resultan". Untuk vektor - vektor segaris.

\section{Metode segitiga untuk penjumlahan vektor}

Cara menggambarkan penjumlahan dua buah vektor dimana salah satu titik tangkap vektor dipindahkan ke ujung vektor yang lain kemudian ditarik garis lurus dari 
pangkal ke ujung vektor tersebut sehingga terbentuklah bangun datar segitiga.

Tahapan-tahapan penjumlahan vektor dengan metode segitiga adalah sebagai berikut:

a. Pindahkan titik tangkap salah satu vektor ke ujung berikutnya,

b. hubungkan titik tangkap vektor pertama ke ujung vektor kedua yang menunjukkan resultan kedua vektor tersebut,

c. Besar dan arah R dicari dengan aturan cosinus dan sinus.

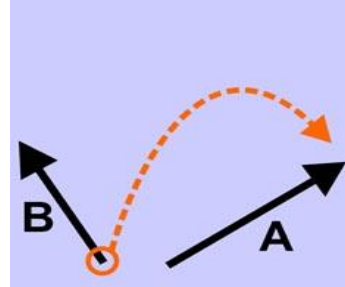

Step \#1

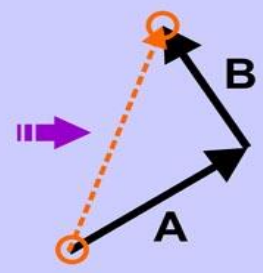

Step \#2

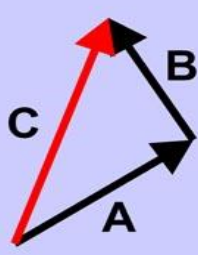

Step \#3

Gambar 2. 1 Resultan vektor metode segitiga

Resultan dari dua vectornya merupakan Garis dari pangkal ke ujung vektor. persamaan resultan vektor A dan B sebagai berikut:

$C=A+B$

$A=C-B$

$B=C-A$

Keterangan : 
C merupakan vektor resultan dari penjumlahan vektor $\mathbf{A}$ dan vektor $\mathbf{B}$, untuk mempermudah kita gunakan trik dibawah ini:

\section{Vektor Resultan = ujung bertemu ujung dan pangkal bertemu}

\section{pangkal}
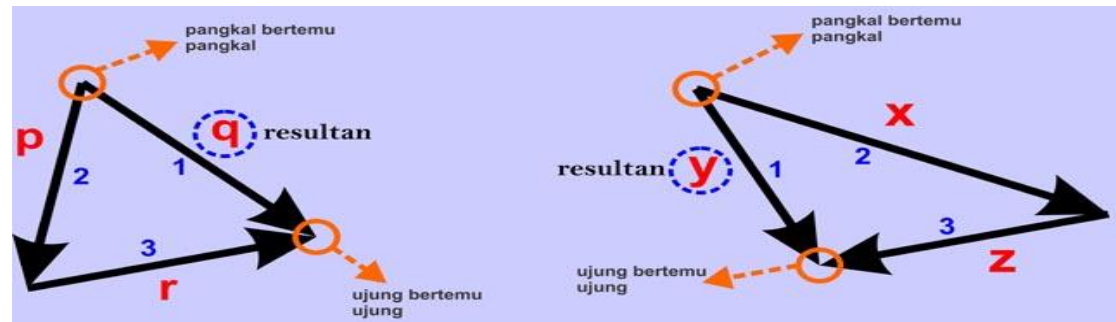

$q=p+r$

\section{$y=x+z$}

Gambar 2. 2 Penjumlahan vektor

Dari gambar 2.1 dapat dituliskan bahwa resultan nya adalah $=\boldsymbol{q}$ $=p+r$

\section{Metode polygon}

Metode ini menggambarkan penjumlahan tiga buah vektor atau lebih dengan saling menghubungkan pangkal vektor ke ujung vektor yang lain sedemikian rupa hingga vektor terakhir.kemudian menarik garis lurus dari pangkal vektor pertama ke ujung vektor terakhir sehingga membentuk bangun segi banyak atau polygon. 


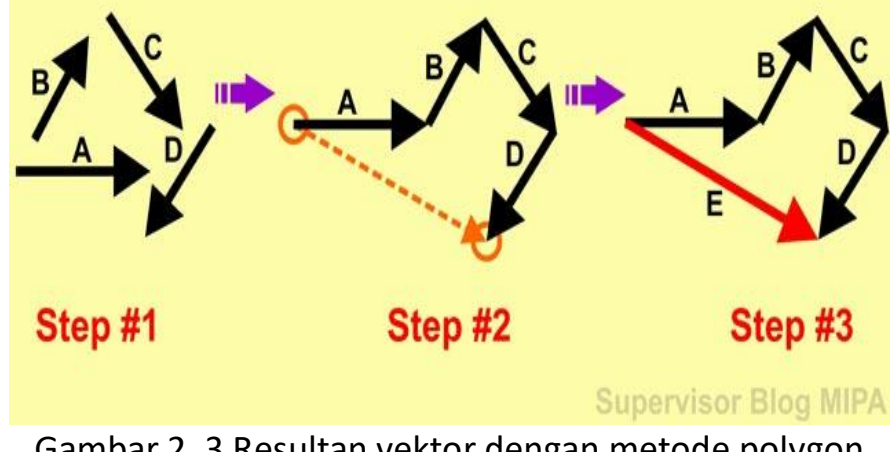

Gambar 2. 3 Resultan vektor dengan metode polygon

Dari gambar diatas dapat ditulis persamaa resultan hasil penjumlahan vektor $\mathbf{A}, \mathbf{B}, \mathbf{C}$ dan $\mathbf{D}$ sebagai berikut:

$\boldsymbol{E}=\boldsymbol{A}+\boldsymbol{B}+\boldsymbol{C}+\boldsymbol{D}$........... pers. (1)

$\boldsymbol{A}=\boldsymbol{E}-\boldsymbol{B}-\boldsymbol{C}-\boldsymbol{D}$........... pers. (2)

$\boldsymbol{A}+\boldsymbol{B}=\boldsymbol{E}-\boldsymbol{C}-\boldsymbol{D}$........... pers. (3)

$\boldsymbol{A}+\boldsymbol{B}+\boldsymbol{C}=\boldsymbol{E}-\boldsymbol{D} \ldots \ldots \ldots . .$. pers. (4)

Keterangan :

E adalah vektor resultan dari penjumlahan vektor A, B, C dan D. Sama seperti pada metode segitiga, untuk menentukan vektor mana yang termasuk resultan dari penjumlahan beberapa vektor pada metode poligon, kita dapat menggunakan trik berikut ini.

Vektor Resultan = ujung bertemu ujung dan pangkal bertemu pangkal

Kesimpulannya untuk menentukan vektor mana yang termasuk resultan adalah dengan melihat ujung dan pangkal vektor-vektor. jika ada sebuah vektor yang ujungnya bertemu 
dengan ujung vektor yang lain dan pangkal vektor tersebut bertemu dengan pangkal vektor yang lain maka vektor itu adalah vektor resultan.

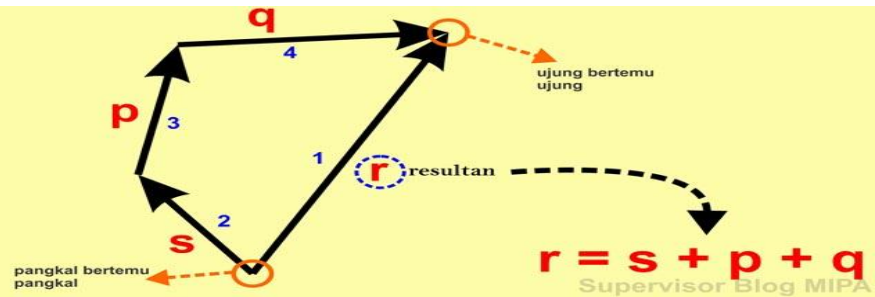

Gambar 2. 4 Resultan 3 buah vektor

Dari gambar diatas dapat dituliskan bahwa vektor $\mathbf{r}$ adalah vektor resultan, dan persamaan resultan nya adalah $=R=S+P+Q$.

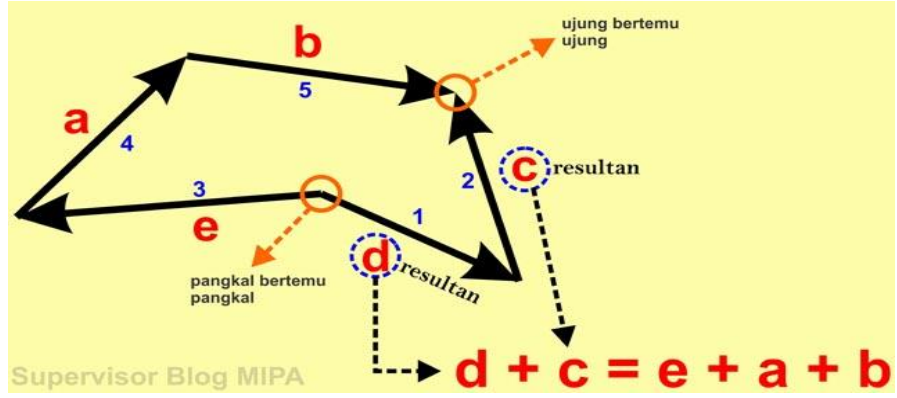

Gambar 2. 5 Resultan 5 vektor

Gambar diatas menjelaskan tentang persamaan 3 dan 4 . Vektor Resultan pada persamaan tersebut bukan merupakan vektor tunggal seperti pada persamaan 1 dan 2, melainkan gabungan dari beberapa vektor. ujung vektor $\mathbf{c}$ bertemu dengan ujung vektor $\mathbf{b}$ dan pangkal vektor $\mathbf{d}$ bertemu degan pangkal vektor e. Karena ujung 
bertemu ujung dan pangkal bertemu pangkal maka bisa dikatakan vektor $\mathbf{d}$ dan c adalah vektor resultannya. Dengan demikian, jumlah vektor d dan c sama dengan jumlah vektor $\mathbf{e}$, a dan b sehingga persamaan resultan vektornya dapat kita tulis sebagai berikut :

$d+c=e+a+b$

\section{Metode jajaran genjang}

Metode jajaran genjang yaitu penjumlahan dua buah vektor yang dilakukan dengan cara menggambarkan kedua vektor saling berhimpitan pangkalnya sebagai dua sisi yang berdekatan dari jajaran genjang. Untuk menjumlahkan dua buah vektor. Resultan dua vektor yang berpotongan adalah diagonal jajargenjang dengan kedua vektor tersebut sebagai sisi jajargenjang, dan ekor resultan $\mathbf{R}$ brimpit dengan ekor kedua vektor tersebut.

\section{Metode analisis}

Metode yang paling baik untuk menentukan resultan dari beberapa vector dan arahnya adalah metode analisis. Metede ini mencari resultan dengan cara perhitungan bukan pengukuran, yaitu dengan menggunakan rumus cosinus dan mencari arah vector resultan dengan menggunakan rumus sinus. 


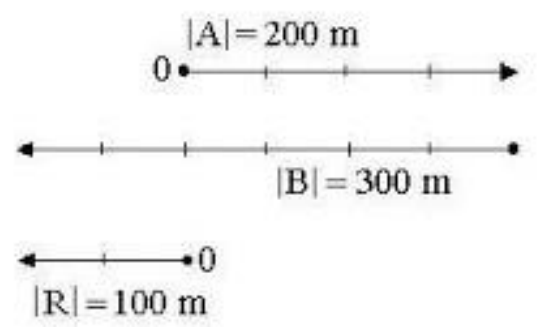

Dari contoh diatas, diketahuai bahwa operasi penjumlahan dalam berhitung berlaku untuk resultan dari dua vektor yang berlawanan arah. Dan juga dua vektor yang searah.

$$
\begin{aligned}
& \left|R^{2}=\right| A^{2}|+| B^{2} \mid \\
& \left|R^{2}=\right| 300^{2} m^{2}|+| 400^{2} m^{2}|| \\
& \left|R^{2}=\right| 90000\left|m^{2}+\right| 160000\left|m^{2}\right| \\
& \left|R^{2}=\right| 250000 m^{2} \mid \\
& \left(R=\sqrt{250000} m^{2}\right) \\
& (R=500 m)
\end{aligned}
$$

Jadi besar vektor resultannya adalah=500 m. untuk menentukan arah vektor resutan terhadap salah satu vektor komponennya kita menggunakan rumus sinus, cosinus dan tangen pada segitiga lihat gambar dibawah ini. 
Rumus Sinus, Cosinus dan Tangen pada Segitiga
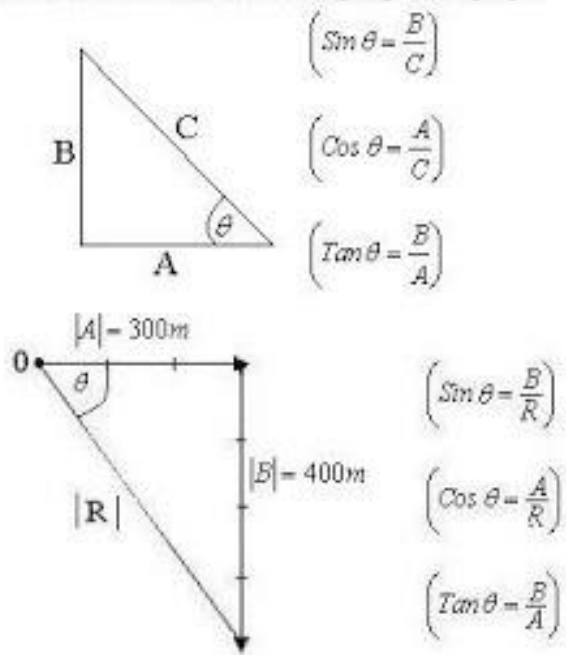

Karena diketahui besar vektor komponen A (300 m) dan besar vektor komponen B (400 m), maka untuk menentukan arah vektor resultan dapat kita gunakan rumus tangen.

Seperti dibawah ini:

$$
\begin{aligned}
& \left(\operatorname{Tan} \theta-\frac{400 m}{300 m}\right) \\
& (\operatorname{Tan} \theta=1,33) \\
& \left(\theta=\operatorname{Tan}^{-1} 1,33=53^{\circ}\right)
\end{aligned}
$$

Jadi, Arah vektor Resultan $=53^{\circ}$ terhadap sumbu $x+$

A. Menentukan Vektor Resultan dengan Rumus Cosinus 
Kita bisa menghitung vektor resultan dari dua vektor yang berarah sembarang dengan menggunakan rumus cosinus. Rumus Cosinus yang digunakan untuk menghitung resultan besar dua vektor yang arahnya sembarang adalah :

$$
R=\sqrt{F_{1}^{2}+F_{2}^{2}+2 F_{1} \cdot F_{2} \cdot \cos \alpha}
$$

Keterangan :

$\mathrm{R}$ : Resultan vektor

$\mathrm{F}_{1}$ : Vektor pertama

$\mathrm{F}_{2}$ :Vektor kedua

Alpha : Sudut apit antara kedua vector

Misalkan terdapat dua vektor, $\mathrm{F}^{1}$ dan $\mathrm{F}^{2}$ seperti dibawah ini: 


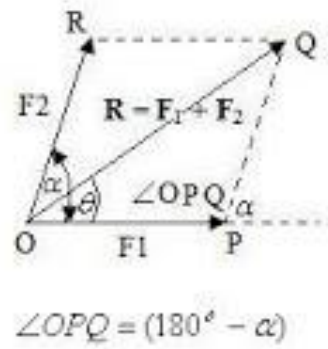

Berdasarkan gambar di atas, kita dapat menurunkan persamaan sebagai berikut

$$
\begin{aligned}
\mathrm{OQ}^{2} & =\mathrm{OP}^{2}+\mathrm{PQ}^{2}-2 \mathrm{OP} \cdot \mathrm{PQ} \cos \angle \mathrm{OAC} \\
& =\mathrm{OP}^{2}+\mathrm{PQ}^{2}-2 \mathrm{OP} \cdot \mathrm{PQ} \cos (180-\alpha) \\
& =\mathrm{OP}^{2}+\mathrm{PQ}^{2}-2 \mathrm{OP} \cdot \mathrm{PQ}(-\cos \alpha) \\
& =\mathrm{OP}^{2}+\mathrm{PQ}^{2}-2 \mathrm{OP} \cdot \mathrm{PQ} \cos \alpha
\end{aligned}
$$

Dan untuk mengetahui arahnya kita menggunakan rumus sinus. Sedangkan untuk mengetahui menggunakan rumus sinus adalah dengan cara berikut ini :

Diketahui dua buah vector $F_{1}$ dan $F_{2}$ membentuk sudut (alpha). Sudut antara vector resultan $(R)$ dengan vector $F_{1}$ adalah (Beta) persamaannya dapat ditulis sebagai berikut.

$\frac{R}{\sin (\alpha)}=\frac{F_{1}}{\sin (\alpha-\beta)}=\frac{F_{2}}{\sin (\beta)}$ 


\section{BAB 3 KESEIMBANGAN PARTIKEL}

Penyebab gerak sumbu benda adalah gaya, dimana semakin besar gaya, maka semakin besar pula percepatan yang dialami. Partikel adalah benda yang ukurannya dapat diabaikan sehingga dapat digambarkan sebagai suatu titik materi. Akibatnya, jika gaya bekerja pada partikel titik tangkap gaya berada tepat pada partikel-partikel tersebut. Oleh karena itu, partikel hanya mengalami gerak translasi dan tidak mengalami gerak rotasi.

Suatu partikel dikatakan dalam keadaan setimbang apabila resultan gaya yang bekerja pada partikel sama dengan nol.

$\Sigma F=0$

Apabila partikel pada bidang xy, maka syarat kesetimbangan adalah resultan gaya pada komponen sumbu $\mathrm{x}$ dan sumbu y sama dengan nol.

$\Sigma \mathrm{F}_{\mathrm{x}}=0$

$\Sigma F_{y}=0$

Berdasarkan Hukum I Newton, jika resultan gaya yang bekerja pada benda sama dengan nol, maka percepatan benda menjadi nol. Artinya, bahwa partikel dalam keadaan diam atau bergerak dengan kecepatan tetap. Apabila partikel dalam keadaan diam disebut mengalami kesetimbangan statis, sedangkan jika bergerak dengan kecepatan tetap disebut kesetimbangan dinamis.

Sebagai contoh, ketika kita meninjuau sebuah gerak bola tenis yang dipukul, kadang kala kita hanya meninjau gerak tranlasinya saja padahal selama geraknya, bola tenis berotasi. 
Sama halnya ketika kita meninjau keadaan setimbang suatu benda. Kita sangat jarang meninjau benda sebagai benar-benar tegar atau elastis. Penyederhanaan sistem biasa dilakukan dengan menganggap benda sebagai partikel atau benda titik.

\section{Syarat kesetimbangan}

Benda dikatakan berada dalam kesetimbangan apabila :

a. Benda itu sebagai satu keseluruhan tetap diam atau bergerak menurut garis lurus dengan kecepatan konstan

b. Benda itu tidak berotasi sama sekali atau berotasi dengan kecepatan tetap

Apabila benda dalam kesetimbangan maka resultan dari semua gaya yang bekerja pada benda tersebut sama dengan nol. Artinya :

$$
\Sigma F x=0 \text { dan } \Sigma F y=0
$$

dimana Fx adalah komponen-komponen gaya pada sumbu $X$ dimana Fy adalah komponen-komponen gaya pada sumbu $Y$ 


\section{BAB IV TITIK PUSAT MASSA DARI MATERIAL DUA DIMENSI}

Titik pusat massa merupakan suatu titik pada suatu benda dimana titik tersebut menjadi titik tangkap dari gaya resultan tanpa dipengaruhi oleh gaya tarik bumi atau gaya grafitasi, Sedangkan titik berat suatu benda merupakan suatu titik pada suatu benda dimana titik tersebut menjadi titik tangkap dari gaya resultan yang dipengaruhi oleh gaya tarik bumi yang arah resultannya ke bawah.

Letak pusat massa adalah titik dalam ruang di antara mereka yang mungkin tidak berhubungan dengan posisi massa manapun pada benda tersebut. Istilah pusat massa sering dipersamakan dengan istilah pusat gravitasi, namun demikian mereka secara fisika merupakan konsep yang berbeda. Letak keduanya memang bertepatan dalam kasus medan gravitasi yang sama, akan tetapi ketika gravitasinya tidak sama maka pusat gravitasi merujuk pada lokasi rerata dari gaya gravitasi yang bekerja pada suatu benda. Hal ini menghasilkan suatu torsi gravitasi, yang kecil tetapi dapat terukur dan harus diperhitungkan dalam pengoperasian satelit-satelit buatan.

Berikut beberapa letak titik pusat massa beberapa benda dua dimensi :

Tabel 4. 1 Tabel Titik pusat massa 


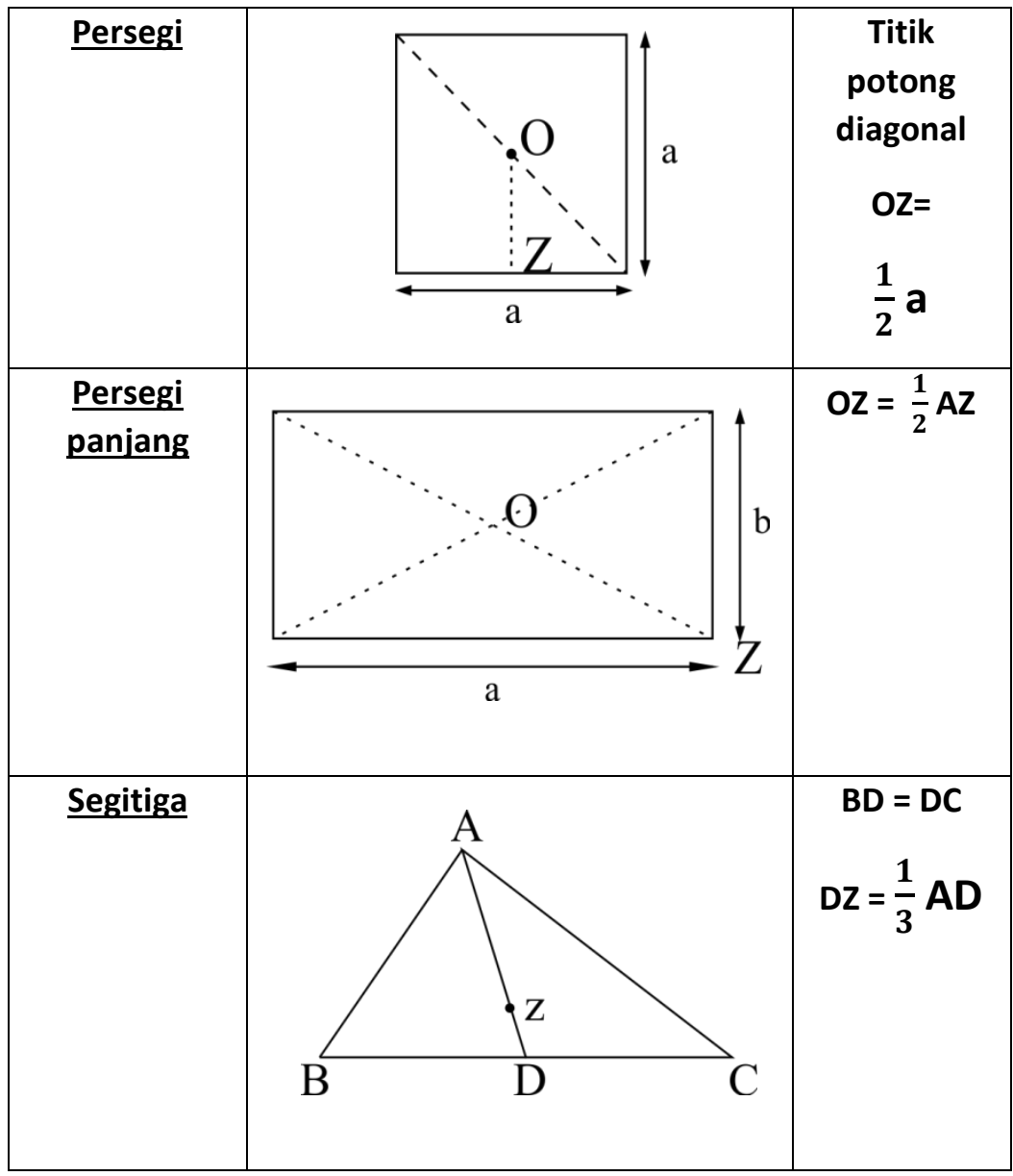




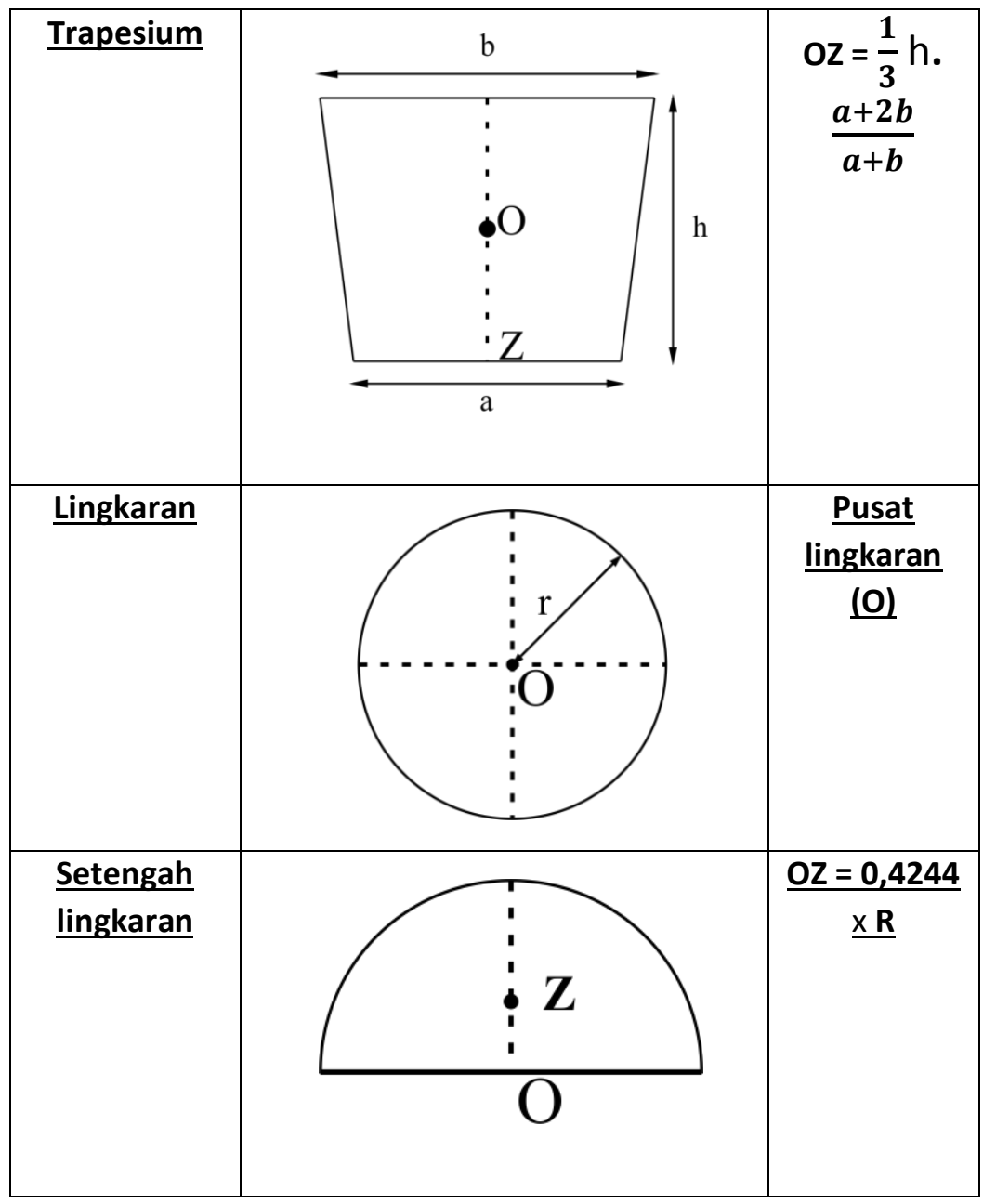

Dari tabel diatas kita bisa menentukan titik koordinat pusat massa dari beberapa jenis penampang dua dimensi namun dalam bidang datar adakalanya kita harus bisa menentukan titik pusat massa dalam bidang bersusun, penampang bidang bersusun merupaakan suatu penmpang yang terdiri dari gabungan dua penampang atau lebih. 


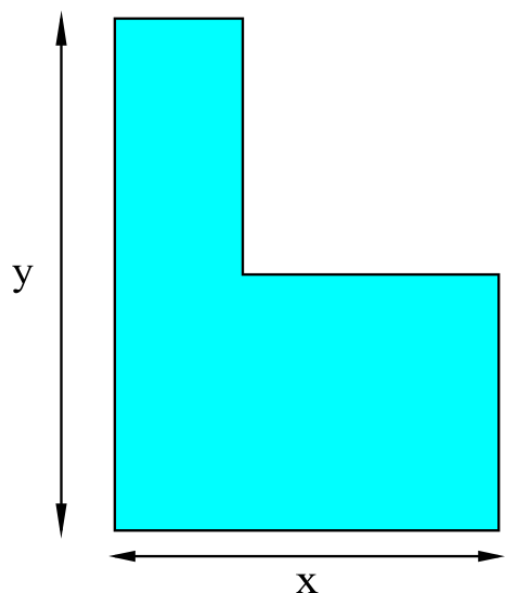

Gambar 4. 1 Penampang bidang bersusun

Berikut cara untuk menentukan koordinat titik pusat massa penampang bersusun sederhana dua dimensi

Untuk menentukan letak koordinat penampang bersusun dalam bidang dua dimensi ada dua macam metode

\section{Cara 1.}

a. Pertama menguraikan bentuk penampang menjadi dua bagian atu lebih 

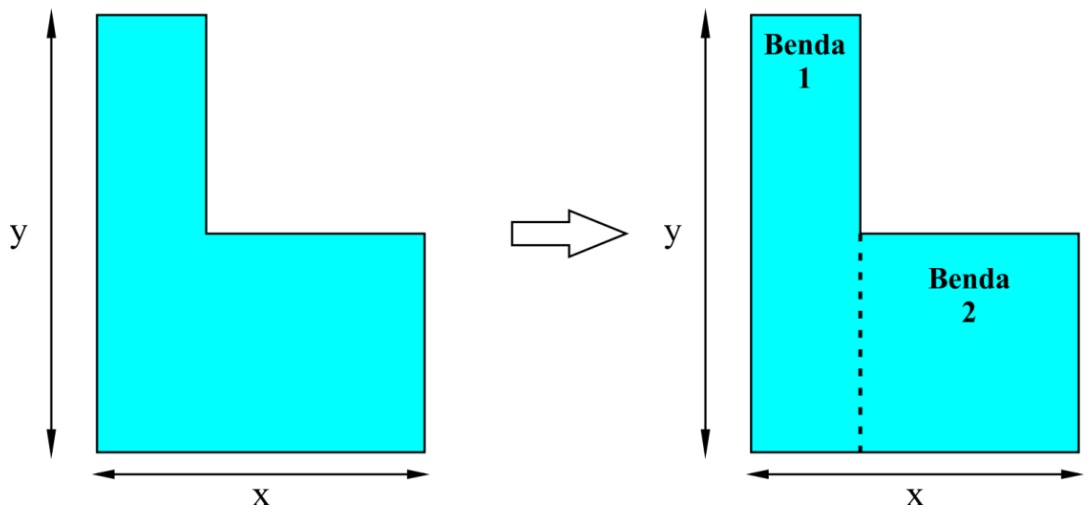

Gambar 4. 2 Penguraian bentuk penampang

b. Kedua menentukan titik $X_{1} X_{2} Y_{1} Y_{2}$

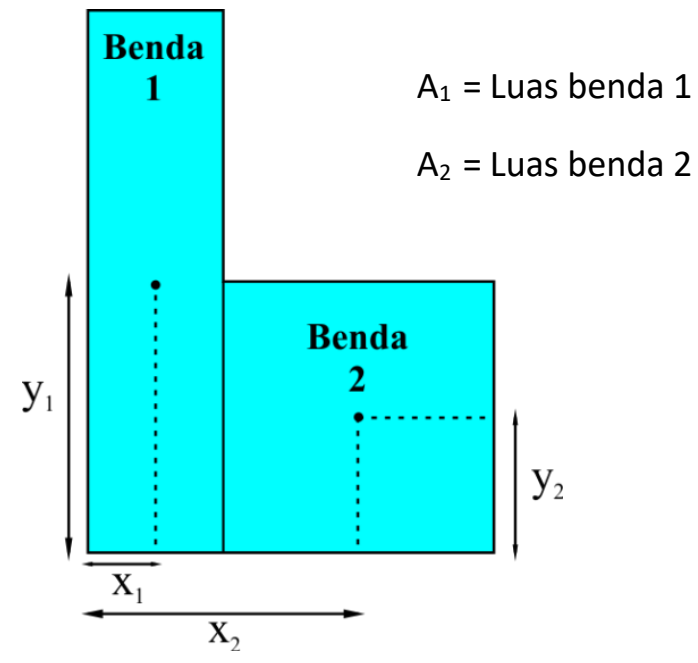

Gambar 4. 3 Penentuan titik x1 x2 y1 y2

c. Ketiga memasukkan nilai $X_{1} X_{2} Y_{1} Y_{2} A_{1} A_{2}$ sesuai dengan rumus

$$
\text { Sumbu } X=\frac{X 1 \cdot A 1+X 2 \cdot A 2}{A 1+A 2}
$$


Sumbu $Y=\frac{Y 1 \cdot A 1+Y 2 \cdot A 2}{A 1+A 2}$

Jadi koordinat titik pusat massa penampang bersusun dua dimensi $=($ Sumbu $x$,Sumbu $y)$

Cara 2 :

d. Pertama mencari bentuk lain daripada penampang tersebut
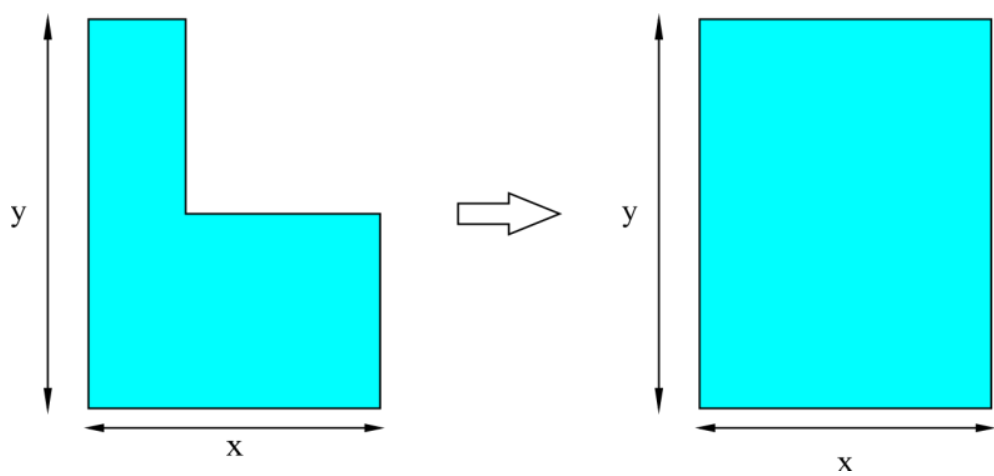

Gambar 4. 4 Membuat bentuk lain penampang

e. Kedua, menguraikan hasil dari perubahan bentuk penampang menjadi dua bagian atau lebih 

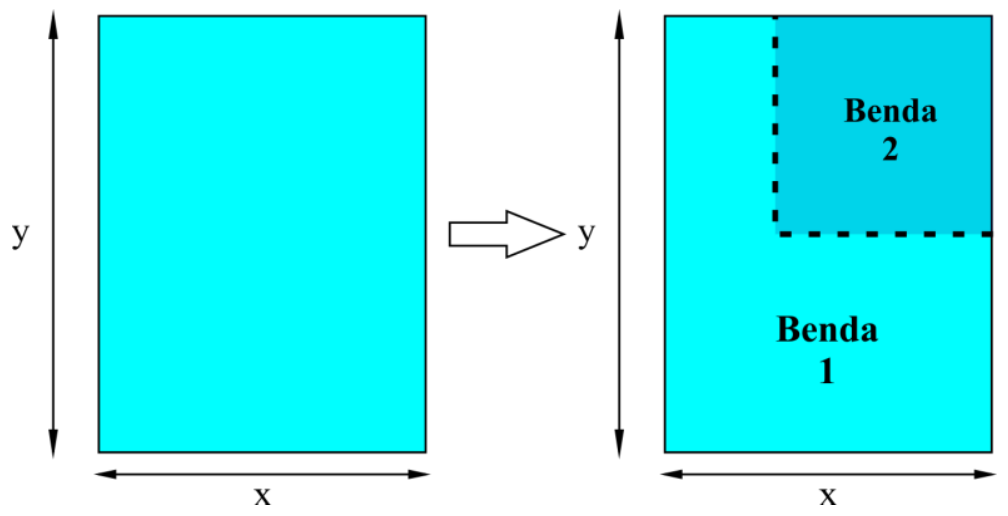

Gambar 4. 5 Bentuk lain penampang 2

f. Ketiga, Menentukan titik $X_{1} X_{2} Y_{1} Y_{2}$

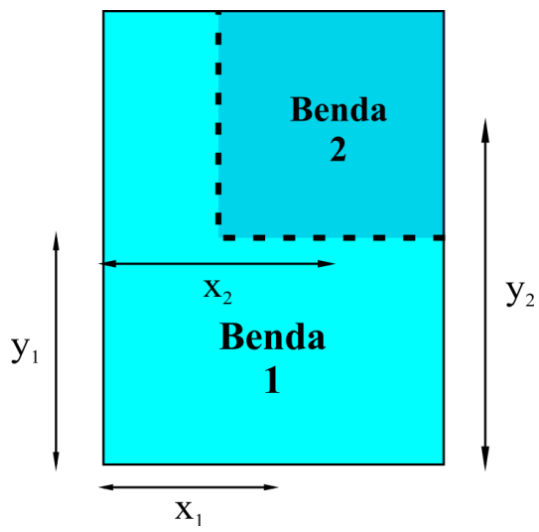

$\mathrm{A}_{1}=$ Luas benda 1

$A_{2}=$ Luas benda 2

Gambar 4. 6 Menentukan titik X1, X2, Y1, Y2

g. Ketiga memasukkan nilai $X_{1} X_{2} Y_{1} Y_{2} A_{1} A_{2}$ sesuai dengan rumus

$$
\begin{aligned}
& \text { Sumbu } X=\frac{X 1 . A 1-X 2 . A 2}{A 1-A 2} \\
& \text { Sumbu } Y=\frac{Y 1 \cdot A 1-Y 2 \cdot A 2}{A 1-A 2}
\end{aligned}
$$


Jadi koordinat titik pusat massa penampang bersusun dua dimensi $=$ (Sumbu $x$,Sumbu y)

\section{Contoh soal}

1. Tentukan titik pusat massa dari penampang dibawah ini

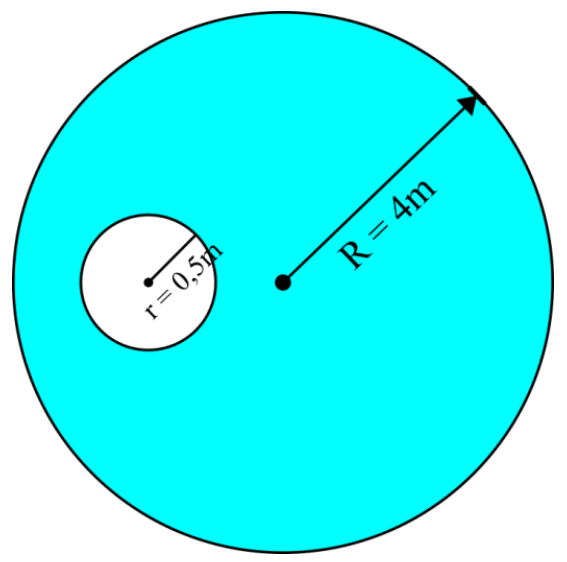

Gambar 4. 7 Penampang lingkaran berlubang

Dengan memperhatikan gambar 4.7. tersebut kita bisa menentukan cara I /II yang dipakai untuk menentukan titik pusat massa, Pada soal ini disarankan untuk menggunakan cara no 2 untuk menyelesaikannya dikarenakan benda tersebut ,merupakan hasil pengurangan bentuk dari benda asliny.a

\section{Jawab}

Diketahui :

1. $R$ (Jari ${ }^{2}$ Lingkaran besar $)=4 \mathrm{~m}$

2. $r\left(\right.$ Jari $^{2}$ Lingkaran kecil $)=1 \mathrm{~m}$ 
Pertama, menguraikan penampang menjadi 2 benda

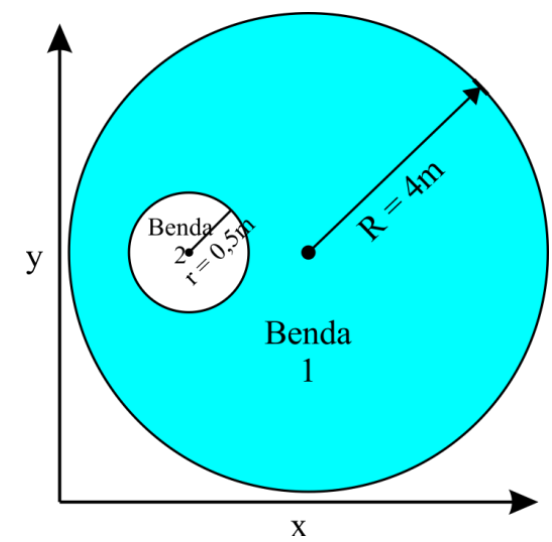

Gambar 4. 8 Menguraikan penampang

Kedua, menentukan titik $X_{1} X_{2} Y_{1} Y_{2}$

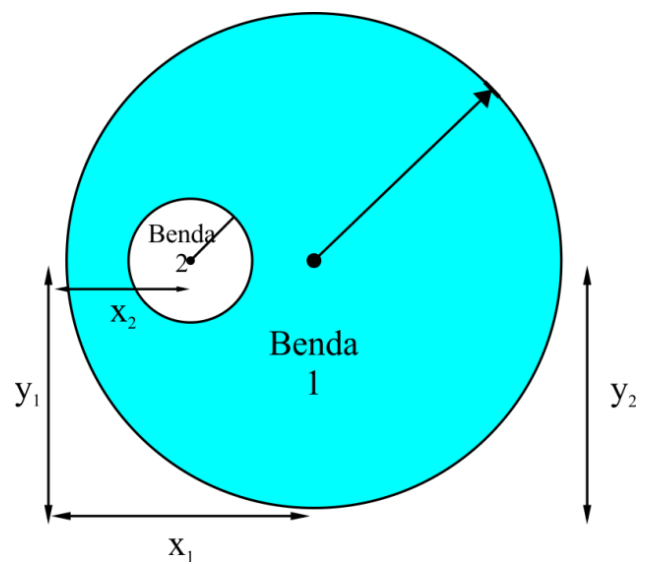

Gambar 4. 9 Menentukan titik X1, X2, Y1, Y2

$$
\begin{aligned}
A_{1}(\text { Luas Benda } 1)=. r^{2} & \\
& =3,14.4^{2} \\
& =50,24 \mathrm{~m}^{2}
\end{aligned}
$$




$$
\begin{aligned}
& \begin{array}{l}
\left.A_{2} \text { (Luas Benda } 2\right)=. r^{2} \\
=3,14 \cdot 0,5^{2} \\
=0,785 \mathrm{~m}^{2}
\end{array} \\
& \begin{aligned}
X_{1}=4 m \\
X_{2}=1 m \\
Y_{1}=4 m \\
Y_{2}=4 m
\end{aligned}
\end{aligned}
$$

Ketiga, memasukkan nilai $X_{1} X_{2} Y_{1} Y_{2} A_{1} A_{2}$ sesuai dengan rumus

$$
\begin{aligned}
& X=\frac{X 1 . A 1-X 2 . A 2}{A 1-A 2} \\
& =\frac{4 \cdot 50,24-1 \cdot 0,785}{50,24-0,785} \\
& =\frac{200,175}{49,455} \\
& =4,04 \mathrm{~m} \\
& Y=\frac{y 1 . A 1-y 2 . A 2}{A 1-A 2} \\
& =\frac{4 \cdot 50,24-4 \cdot 0,785}{50,24-0,785} \\
& =\frac{197,82}{49,455} \\
& =4,00 \mathrm{~m}
\end{aligned}
$$


Jadi titik pusat massa dari penampang tersebut adalah $x, y(4,04 \mathrm{~m}$, $4 \mathrm{~m})$

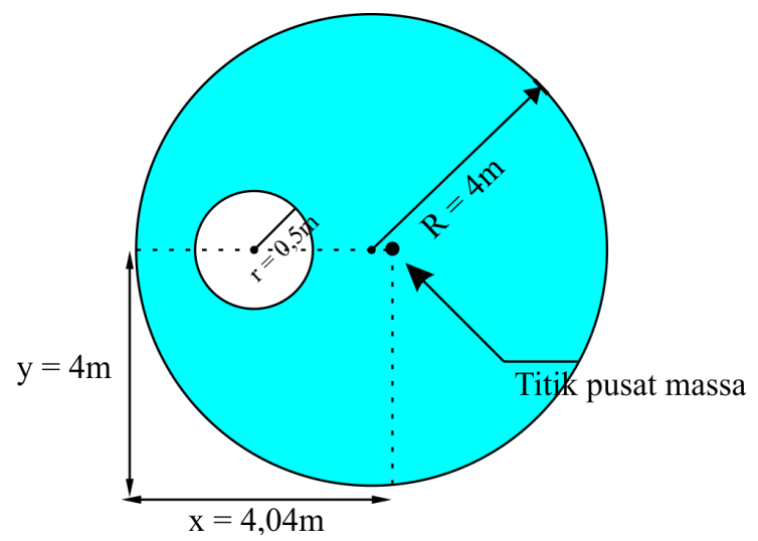

Gambar 4. 10 Penentuan titik pusat massa 


\section{BAB V TITIK PUSAT MASSA DALAM BENDA TIGA DIMENSI}

\subsection{Analisis teoritik}

Titik pusat massa dalam bidang 3 dimensi merupakan suatu titik dimana titik tersebut merupakan pusat dari pada semua sumbu benda tersebut yang meliputi sumbu $\mathrm{x}$, sumbu $\mathrm{y}$, sumbu z. Titik pusat massa pada benda 3 dimensi ini merupakan titik kesetimbangan yang mana letaknya berada 1/2 dari panjang sumbu $\mathrm{x}$, sumbu y dan sumbu z

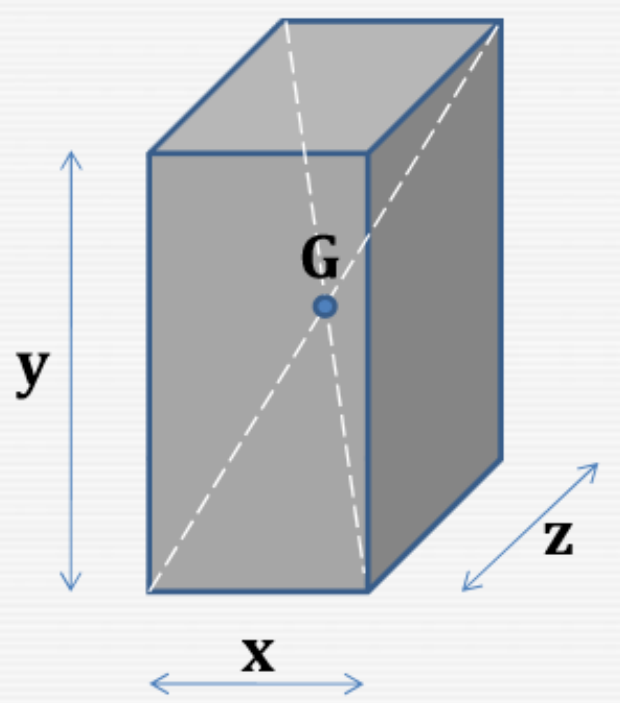

Gambar 5. 1 Titik pusat massa balok

Letak titik pusat massanya adalah $\mathrm{T}=(1 / 2 . \mathrm{X}$ ,1/2.Y,1/2.Z )

Bagaimana dengan bentuk benda seperti berikut ini 

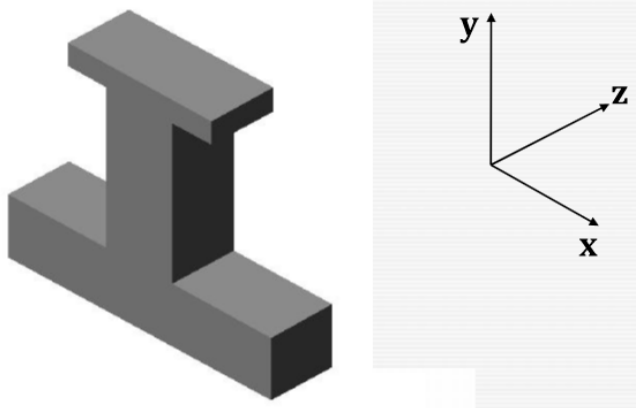

Gambar 5. 2 Profil tiga dimensi

Berikut penjelasannya:

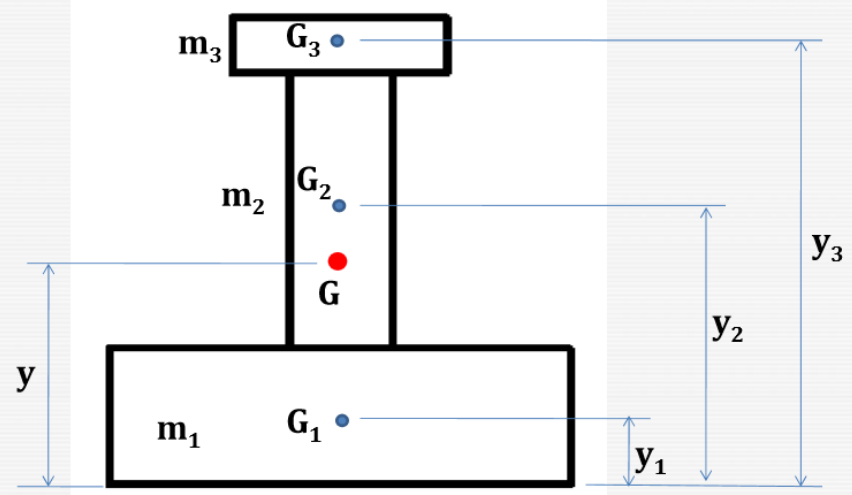

$$
\mathrm{x}=\frac{\sum \mathrm{m}_{\mathrm{n}} \mathrm{x}_{\mathrm{n}}}{\sum \mathrm{m}_{\mathrm{n}}} \quad \mathrm{y}=\frac{\sum \mathrm{m}_{\mathrm{n}} \mathrm{y}_{\mathrm{n}}}{\sum \mathrm{m}_{\mathrm{n}}} \quad \mathrm{z}=\frac{\sum \mathrm{m}_{\mathrm{n}} \mathrm{z}_{\mathrm{n}}}{\sum \mathrm{m}_{\mathrm{n}}} \quad \mathrm{n}=1,2, \ldots
$$

$$
\begin{aligned}
& \mathrm{m}=\text { massa benda }=\rho \mathrm{V} \\
& \mathrm{V}=\text { volume benda }
\end{aligned}
$$

Gambar 5. 3 Penguraian titik pusat massa 
Berikut menggunakan percobaan statika

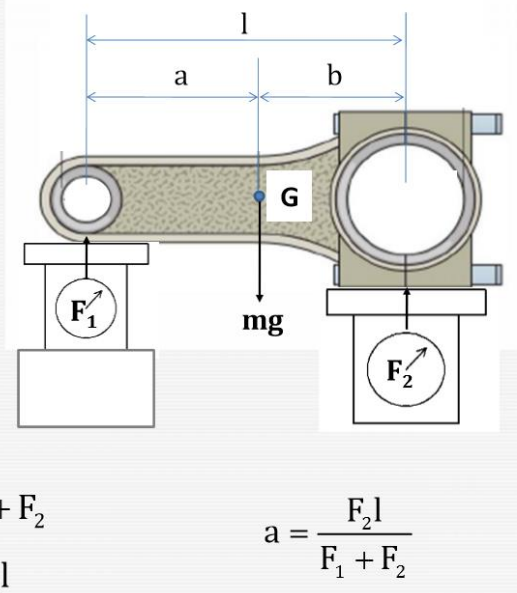

Gambar 5. 4 Penentuan titik pusat massa profil 3 dimensi

Dimana:

$\mathrm{G}=$ Lokasi pusat berat massa

Jika indikator pada kedua timbangan menunjukan gaya gaya $F_{1}$ dan $F_{2}$, maka dengan menjumlahka momen dititik tumpu 
sebelah kiri akan deperoleh jarak a

$-F_{2} \cdot L+m g \cdot a=0$

$$
a=\frac{F_{2} \cdot L}{m g}
$$

Karena $m g=F_{1}+F_{2}$, maka :

$$
\begin{aligned}
& a=\frac{F_{2} \cdot L}{F_{1}+F_{2}}, \text { dan } \\
& b=L-a \ldots \ldots \ldots . . .
\end{aligned}
$$

\subsection{Titik Pusat Massa Dalam Numerik}

Metode numerik untuk menghitung suatu integral tertentu dengan metode Monte- Carlo dapat dijabarkan secara murni matematis (Koonin, 1990; DeVries, 1994), atau dengan metode sederhana, yang disebut metode "Hit-or-Miss", (Sobol, 1993). Mencari nilai suatu integral tertentu suatu fungsi adalah sama dengan menghitung luas yang dibatasi oleh kurva fungsi itu dan batas- batas integralnya. Bila daerah yang akan dihitung luasnya berupa suatu daerah yang bentuknya tidak beraturan, metode monte- Carlo dapat digunakan. Misal akan dihitung luas suatu bangun sem- barang $\mathrm{S}$ yang berada di dalam suatu daerah bangun persegi seperti ditunjukkan pada gambar 


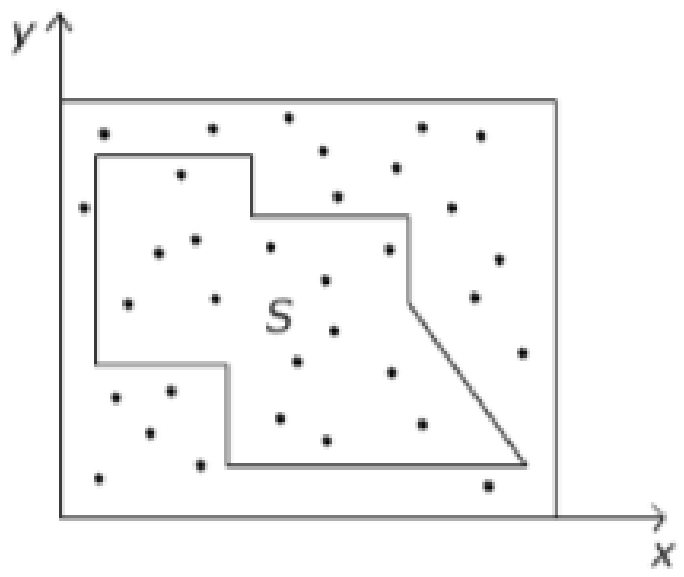

Gambar 5. 5 Profil bangun tidak beraturan

Pilih sejumlah $\mathrm{N}$ titik di dalam daerah persegi secara acak, dan untuk titik-titik yang masuk di dalam daerah $\mathrm{S}$ diberi simbol $\mathrm{n}$. Secara geometri, nampak bahwa per- bandingan luas bangun $S$ dapat didekati dengan perbandingan $n / N$. Jika luas bangun $S$ adalah AS dan luas bangun persegi adalah AP, maka

$$
A_{s}=n / N \cdot A p
$$

Ketidakpastian $\sigma$ dalam penentuan $\mathrm{n}$ diberi- kan oleh deviasi standar dari agihan binomi- al dengan kebolehjadian $\mathrm{p}=$ AS/AP (Beving- ton, 2003)

$$
\sigma=\sqrt{N p(1 \quad p)} \quad \sqrt{n(1 \quad p)}
$$

sehingga hasilnya disajikan sebagai $\mathrm{n} \pm \sigma$ Ketidakpastian relatifnya, 


$$
\frac{\sigma}{n}=\frac{\sqrt{n(1-p)}}{n} \quad \sqrt{\frac{1-p}{n}}
$$

yang menunjukkan bahwa ketidakpastian relatif pada hasil berbanding terbalik denganakar kuadrat $n$, yang berarti semakin besar $\mathrm{N}$ maka semakin akurat penentuan luas $\mathrm{S}$. Cara numerik untuk menentukan nilai $\pi$ adalah dengan menghitung luas $1 / 4$ lingkaran berjejari 1 , seperti ditunjukkan pada Gambar 2. Luas sebenarnya adalah $1 / 4 \pi$.

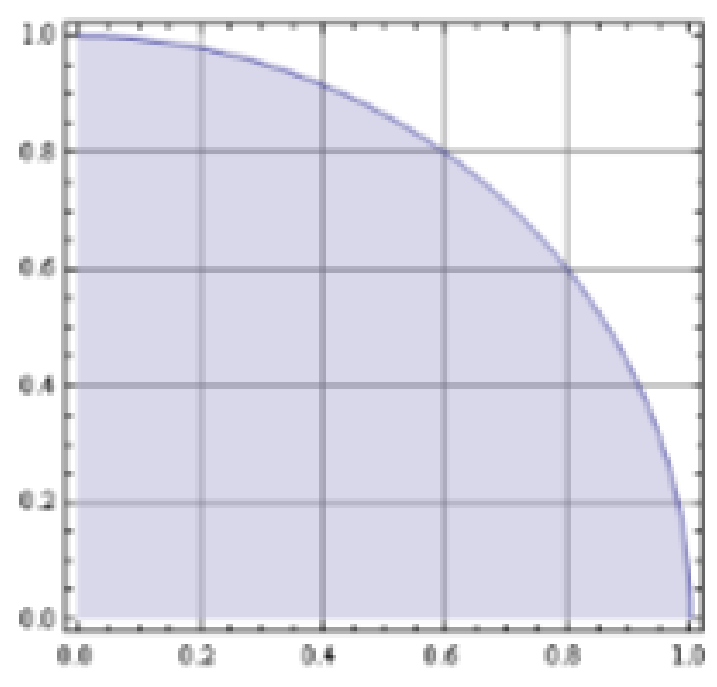

Gambar 5. 6 Profil $1 \frac{1}{4}$ lingkaran

Titik-titik dibangkitkan secara acak pada interval $01 \mathrm{x} \leq \leq$ dan $01 \mathrm{y} \leq \leq$. Pada Excel, bilangan acak dibangkitkan dengan rumus : RAND(), yang akan memberikan nilai acak antara 0 sampai 1 . Rumus tersebut diisikan pada dua sel untuk membangkitkan nilai $\mathrm{x}$ dan $\mathrm{y}$. 
Selanjutnya koordinat itu diuji apakah berada di dalam luasan $1 / 4$ lingkaran atau tidak dengan syarat

$$
\sqrt{x^{2}+y^{2}}<1
$$

Jika dari sebanyak $\mathrm{N}$ koordinat acak ada sebanyak $\mathrm{n}$ yang berada di dalam $1 / 4$ ling- karan, maka nilai $\pi$ bisa didekati dengan

$$
\pi \cong \frac{n}{N} \times 4
$$

\section{Menentukan titik pusat massa}

Gambar 1 jika diterapkan pada bentuk 3 di- mensi, maka titiktitik dibangkitkan secara acak pada suatu volume bangun sederhana $\mathrm{V}$ yang di dalamnya ada bangun sembarang $\mathrm{W}$. Volume bangun sembarang dapat didekati dari hasil kali $\mathrm{V}$ dengan prosentase titik yang berada di dalam $W$ dengan jumlah kese- luruhan titik.

Dengan memandang titik-titik yang berada di dalam volume $\mathrm{W}$ sebagai suatu sistem partikel dengan massa yang sama, maka secara pendekatan dapat dicari titik pusat massa dari W. Bentuk yang akan diacari titik pusat massanya adalah toroida terpotong seperti pada Gambar 3 (Press, 2007). 


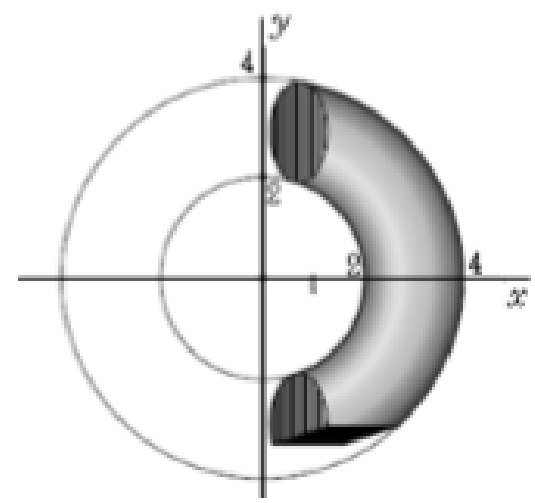

Gambar 5. 7 Toroida terpotong

Persamaan untuk toroidanya adalah

$$
z^{2}+\left(\sqrt{x^{2}+y^{2}}-3\right)^{2} \leq 1
$$

dengan batas pemotongan

$$
x \geq 1 \text { dan } y \geq 3
$$

menentukan bentuk rumus randomnya, yaitu $x$ berada antara 1 sampai 4 , y antara -3 sampai 4 dan $z$ antara -1 sampai 1 (tidak dipotong pada sumbu-z). Rumus- rumus tersebut dituliskan berturut-turut pa- da sel A5, B5, dan C5, seperti ditampilkan pada Gambar 5. Pada sel D5 diisikan rumus

Jika terdapat sebanyak $\mathrm{n}$ titik yang berada di dalam, maka koordinat pusat massanya didekati dengan (Serway, 2004). 


$$
\begin{aligned}
& x_{c m} \approx \frac{\sum_{i=1}^{n} m_{i} x_{i}}{M}=\frac{m \sum_{i=1}^{n} x_{i}}{n m}=\frac{\sum_{i=1}^{n} x_{i}}{n} \\
& y_{c m} \approx \frac{\sum_{i=1}^{n} m_{i} y_{i}}{M}=\frac{m \sum_{i=1}^{n} y_{i}}{n m}=\frac{\sum_{i=1}^{n} y_{i}}{n} \\
& z_{c m} \approx \frac{\sum_{i=1}^{n} m_{i} z_{i}}{M}=\frac{m \sum_{i=1}^{n} z_{i}}{n m}=\frac{\sum_{i=1}^{n} z_{i}}{n}
\end{aligned}
$$

dengan menganggap bahwa semua titik koordinat (sebagai titik partikel) massanya sama. Dengan kata lain, benda dianggap homogen, sehingga kerapatannya tetap dan sama di semua titik. Dengan demikian, untuk setiap iterasi, setelah titik diuji, jika berada di dalam vol- ume toroida, nilai-nilai $x, y$ dan z diakumu- lasikan, kemudian hasil akhirnya dibagi dengan total titik di dalam volume untuk memperoleh titik koordinat pusat massanya.

. Sebagai contoh untuk $\mathrm{N}=100$ menjadi $\mathrm{N}=400$, faktor kelipatannya $\mathrm{p}=4$, ketakpastian relatifnya menjadi setengahnya. Oleh karena itu dengan menambah $\mathrm{N}$ dari 1000 menjadi 2000 tidak banyak berpengaruh pa- da ketakpastian relatif, walaupun secara komputasi langkah perhitungan menjadi lebih besar dan waktu yang diperlukan juga lebih lama. Jadi ada batas untuk menentukan seberapa $\mathrm{N}$ agar sesuai dengan ketak- pastian yang diharapkan 


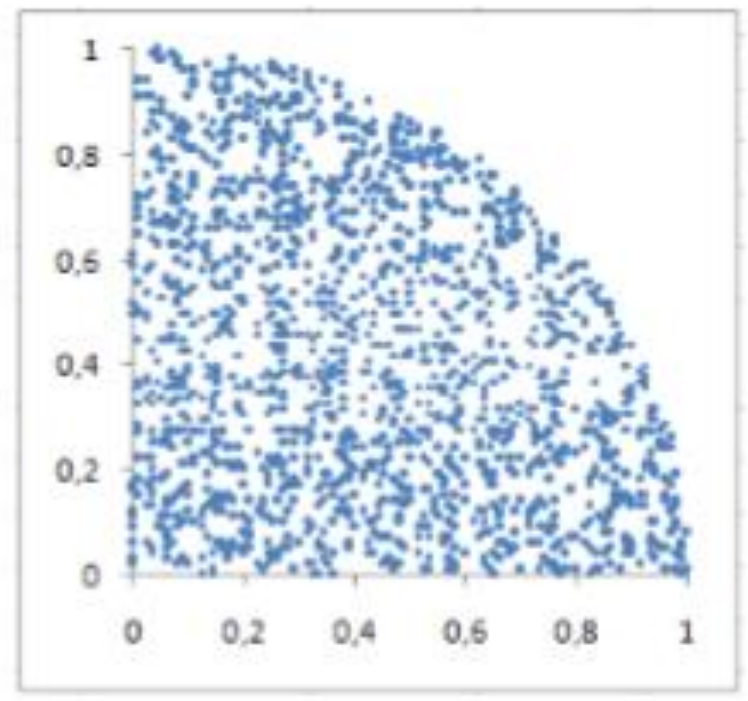

Gambar 5. 8 Hasil untuk N= 2000

Menentukan titik pusat massa 


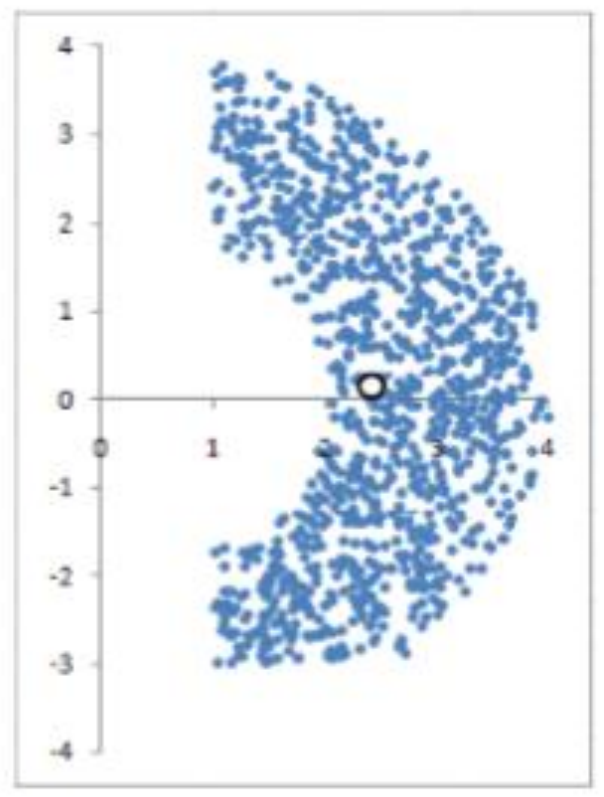

Gambar 5. 9 Grafik xy

Sejumlah 2000 titik data acak yang dibangkitkan pada suatu bangun geometri yang melingkupi volume toroida terpotong. Bangun tersebut memiliki ukuran : 2 (batas- batas pada sumbu-z), 7 (batasbatas pada sumbu-y) dan 3 (batas-batas pada sumbu-x), sehingga volumenya adalah $2 \times 7 \times 3$. Gambar 6 menampilkan grafik 2 dimensi titik-titik yang berada di dalam toroida terpotong. Sumbu vertikal adalah sumbu-y sedangkan sumbu horisontal adalah sumbu-x. 


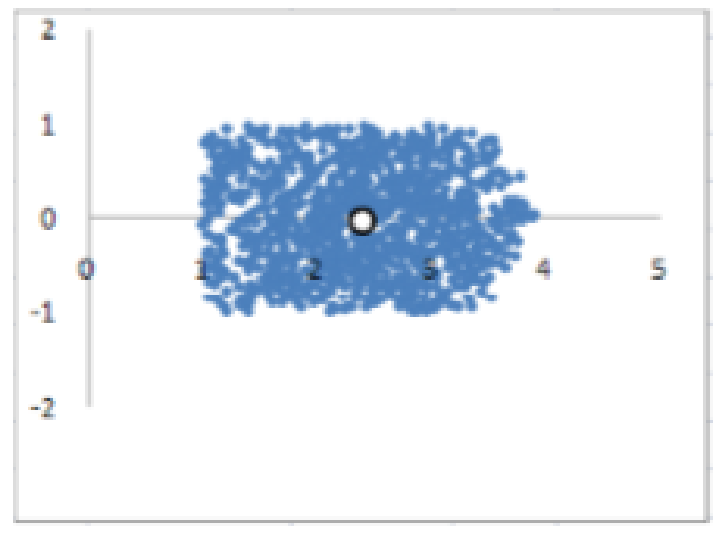

Gambar 5. 10 Grafik yz

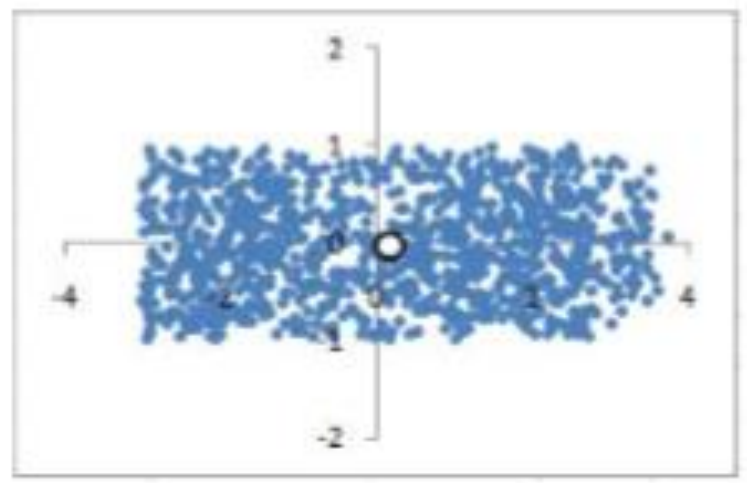

Gambar 5. 11 Grafik xz

Titik besar berwarna merah adalah titik pusat massa hasil perhitungan. Dapat dilihat bahwa ada kemiripan antara Gambar 6 dengan Gambar 3. Gambar 7 dan 8 menam- pilkan grafik 2-dimensi xz dan yz untuk ob- jek yang sama. 


\section{BAB VI STRUKTUR BEBAN TERPUSAT DAN BEBAN TERDISTRIBUSI}

\subsection{Analisa Beban Terpusat}

Beban terpusat merupakan beban yang terkonsentrasi di suatu tempat yang menjadi titik keseimbangan dari benda tersebut jadi apabila kita mencari titik keseimbangan suatu benda maka yang harus kita lakukan adalah mencari beban terpusat terlebih dahulu. Berikut tipe tipe beban:

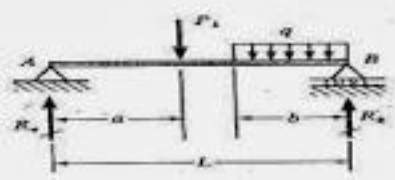

(a)

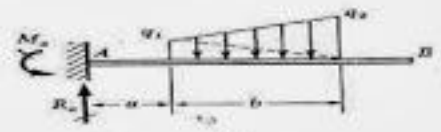

(b)

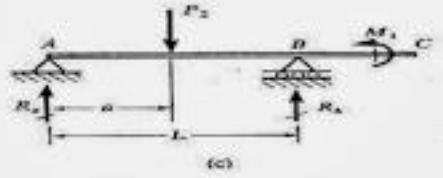

(e)

Tipe-tipe beban pada Balok

Gambar 6. 1 Gambar Beban pada balok

Berikut contoh soal mengenai balok sederhana dengan beban terpusat 


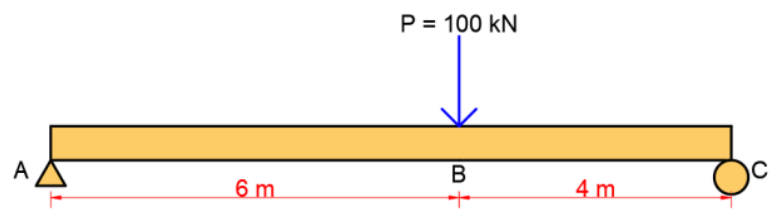

Gambar 6.2 balok dengan dua tumpuan

Kita akan membahas mengenai hasil reaksi yang terjadi pada setiap tumpuan (sendi - rol), analisa gaya-gaya dalam yaitu gaya geser, gaya normal, dan momen, sampai terakhir penggambaran diagramdiagramnya. Berikut tahap-tahap penyelesaian terhadap soal-soal tersebut.

1. Menghitung nilai reaksi yang terjadi pada setiap tumpuan (sendi - rol) dalam kasus ini yaitu reaksi pada titik $A$ dan $C$

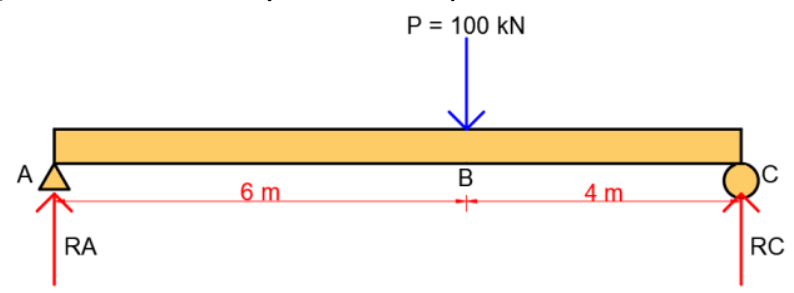

Gambar 6. 3 Balok dua tumpuan

Sehingga terdapat reaksi vertikal pada setiap tumpuan A dan C yaitu RA dan RC.

Maka dari itu kita cari nila RA dengan statis momen ke titik $C$ (anggap rotasi ada di titik $C$ ). sehingga didapat :

$(R A \times 10)-(P \times 4)=0$ Nilai 4 merupakan jarak $P$ ke titik $C$

INGAT ROTASI BEBAN TERPUSAT P KE ARAH KIRI SEHINGGA NEGATIF (-) (karena arah beban $P$ ke bawah dan pusat rotasi ada di titik C)

$(\mathrm{RA} \times 10)-(\mathrm{P} \times 4)=0$

$(10 R A)-(100 \times 4)=0$ 
10RA $-400=0$

RA $=400 / 10=40 \mathrm{kN}$ (HASIL POSITIF REAKSI KE ARAH ATAS)

Kemudian kita cari nilai RC dengan cara statis momen ke titik $A$ (anggap rotasi ada di titik $A)$.

$-(R C \times 10)+(P \times 6)=0$ Nilai 6 merupakan jarak $P$ ke titik $A$ ROTASI BEBAN TERPUSAT $P$ KE ARAH KANAN KARENA PUSAT ROTASI ADA DI TITIK A SEHINGGA BERNILAI POSITIF (+) (karena arah beban $P$ ke bawah dan pusat rotasi ada di titik $A$ )

$-10 R C+(100 \times 6)=0$

$-10 R C+600=0$

$\mathrm{RC}=600 / 10=60 \mathrm{kN}$ (HASIL POSITIF REAKSI KE ARAH ATAS)

Maka hasilnya adalah $\mathrm{RA}=40 \mathrm{kN}$ dan $\mathrm{RC}=60 \mathrm{kN}$ yang dapat dilihat pada gambar di bawah ini.

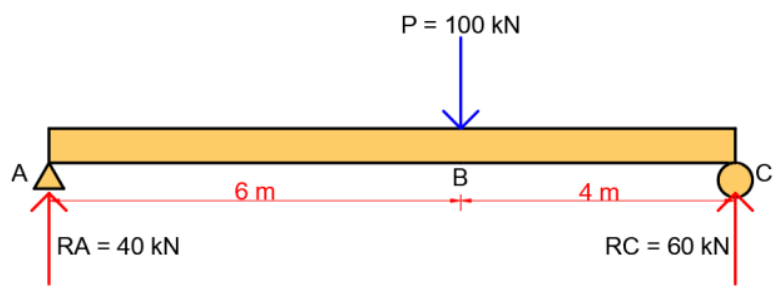

Gambar 6. 4 Hasil perhitungan reaksi balok bertumpuan

2. Analisa Gaya-Gaya Dalam Diantaranya Gaya Geser, Gaya Normal, Dan Gaya Lintang Atau Momen

6.2. Analisa Gaya Geser

- Potongan $1(0-6 \mathrm{~m})$ 


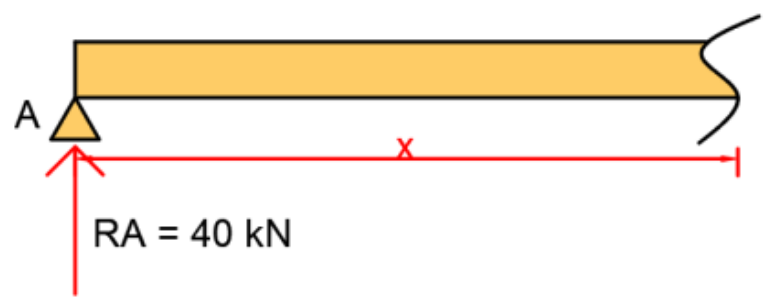

Gambar 6. 5 Balok dengan tumpuan tunggal

$\mathrm{Q}(0-6)=\mathrm{RA}=40 \mathrm{kN}$ (Bernilai Positif (+) karena arah reaksi ke atas) Perlu diingatkan pada jarak 0 sampai 6 meter gaya geser bernilai sama sebesar $40 \mathrm{kN}$ karena tidak terdapat beban sepanjang 0 sampai 6 meter

- Potongan $2(6-10 \mathrm{~m})$

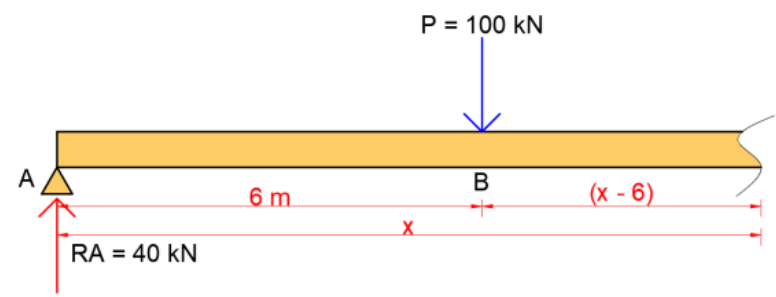

Gambar 6. 6 Balok tumpuan dengan beban tunggal

$\mathrm{Q}(6-10)=\mathrm{RA}-\mathrm{P}=40-100=-60 \mathrm{kN}$ (Bernilai Negatif $(-)$ karena beban ke arah bawah lebih besar)

Sehingga gambar diagram gaya geser dapat dilihat seperti pada gambar di bawah ini. 


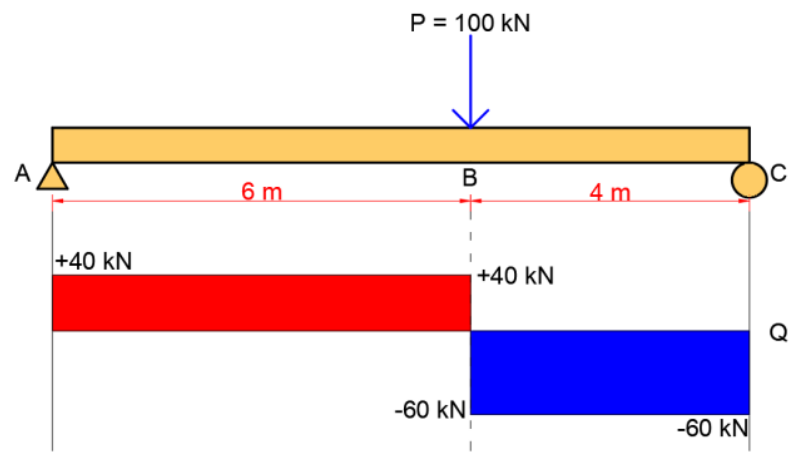

Gambar 6. 7 Diagram gaya geser balok tumpuan

\subsection{Analisa Gaya Lintang/Momen}

- Potongan $1(0-6 \mathrm{~m})$

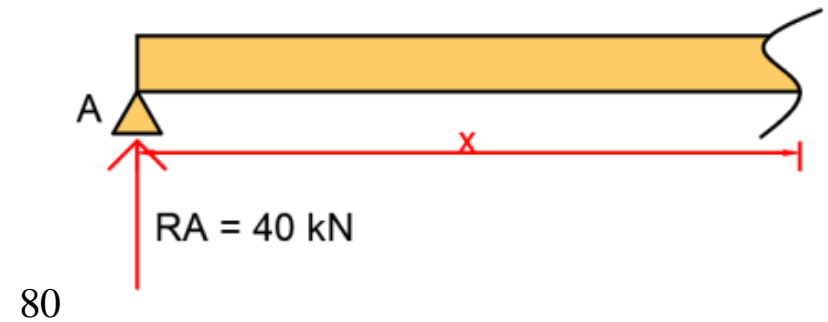

Gambar 6. 8 Potongan 1

Mx = RA . $x$ (Ingat Momen merupakan gaya dikali jarak)

Mari kita cari momen pada jarak (2, 4 dan 6) ingat interval jarak pada potongan 1 adalah 0 sampai dengan 6 meter.

Untuk $\mathrm{x}=2$ maka $\mathrm{M} 2=40 \times 2=80 \mathrm{kNm}$

Untuk $\mathrm{x}=4$ maka $\mathrm{M} 4=40 \times 4=160 \mathrm{kNm}$

Untuk $x=6$ maka M6 $=40 \times 6=240 \mathrm{kNm}$

Perlu kita ketahui bahwa $\mathrm{x}$ berpangkat 1 maka setiap perubahan nilai $x$ adalah linier maka nantinya diagram gaya lintang akan membentuk garis linier dari jarak 0 sampai dengan 6 meter. 
- Potongan $2(6-10 \mathrm{~m})$

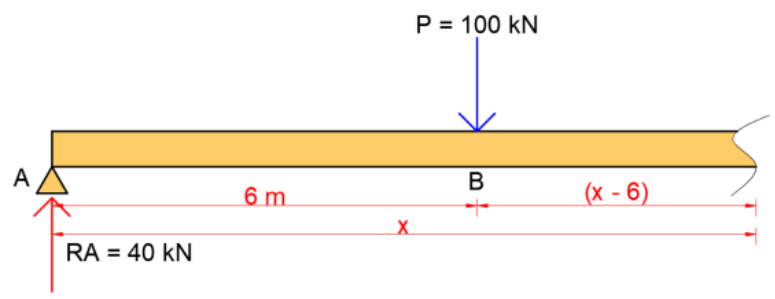

Gambar 6. 9 Potongan 2

$M x=(R A . x)-P .(x-6)$ Ingat pusat rotasi ada pada titik $C$

Mari kita cari momen pada jarak (6, 8 dan 10) ingat interval jarak pada potongan 2 adalah 6 sampai dengan 10 meter.

Untuk $\mathrm{x}=6$ maka M6 $=(40 \times 6)-100 .(6-6)=240 \mathrm{kNm}$

Untuk $\mathrm{x}=8$ maka $\mathrm{M} 8=(40 \times 8)-100 .(8-6)=120 \mathrm{kNm}$

Untuk $\mathrm{x}=10$ maka $\mathrm{M} 10=(40 \times 10)-100 .(10-6)=0 \mathrm{kNm}$

Ingat bahwa $x$ berpangkat 1 maka setiap perubahan nilai $x$ adalah linier maka nantinya diagram gaya lintang akan membentuk garis linier dari jarak 6 sampai dengan 10 meter.

Lihat bahwa pada $x=6$ menunjukkan hasil yang sama yaitu sebesar 240 kNm. Hasil ini merupakan nilai Momen maksimum.

Mengapa momen maksimum terletak pada jarak 6 meter dari titik A ?Karena pada titik tersebut $(x=6 \mathrm{~m})$ tepat terdapatnya beban terpusat $P$.

Oke dapat kita gambarkan diagram gaya Lintang atau momen sebagai berikut.

80 


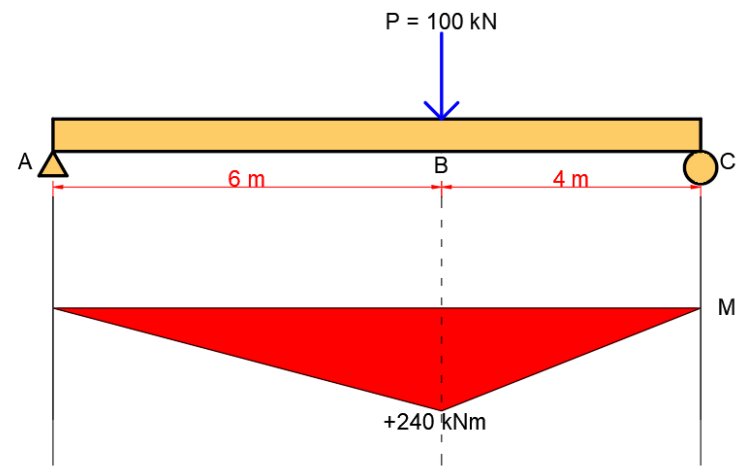

Gambar 6. 10 Diagram Momen batang dua tumpuan

Perlu diingat kembali GAYA NORMAL HANYA ADA APABILA TERDAPAT BEBAN HORIZONTAL.

Menggambarkan diagram N, Q dan M lengkapBerikut gambar lengkap diagram $\mathrm{Q}$ dan $\mathrm{M}$.

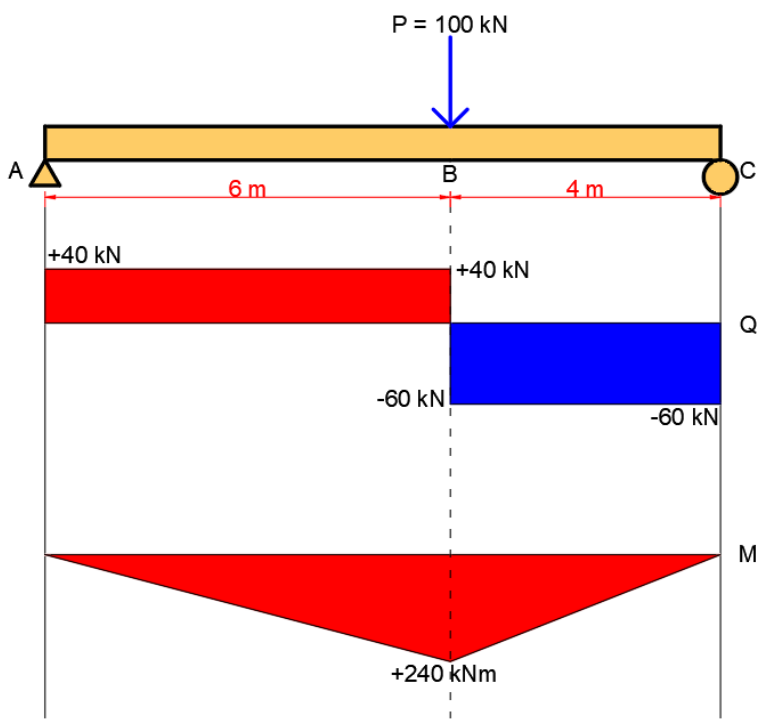

Gambar 6. 11 Diagram geser dan momen 


\section{BAB VII ANALISA STRUKTUR}

Pada saat ini rangka batang sangat penting untuk pembangunan, seperti kontruksi uintuk atap, jembatan, menara atau banguna tinggi lainnya. Bentuk struktur rangka dipilih karena mampu menerima beban struktur relatif besar dan dapat melayani kebutuhan bentang struktur yang panjang. Struktur rangka dapat memberikan estetika yang tinggi untuk kontruksi, seperti kontruksi menara EIFEL di paris ataupun kontruksi seperti stadion sepak bola di Eropa. Dalan dunia arsitektur dan struktural, rangka batang adalah kontruksi yang tersusun dari batang-batang tarik dan batang-batang tekan saja, umumnya terbuat dari baja atau kayu .

Bentuk paling sederhana dari struktur rangka adalah rangkaian batang yang dirangkai membentuk satu atau lebih unit segitiga. Pola susunan segitiga dipilih karena merupakan struktur yang stabil. Stuktur rangka umumnya terletak pada dua perletakan yang prinsipnya sama dengan perletakan pada struktur balok, yakni perletakan sendi atau rol. Titik rangkai yang menghubungkan elemen rangka disebut sebagai mode atau titik sambung.

Dengan maksud untuk menjelaskan :

1. Definisi truss

2. Truss sederhana

3. Analisa truss dengan metode join

4. Analisa truss dengan metode section

5. Truss komplek

\subsection{Definisi Truss}

Truss berasal darikata Prancis tua,"trousse" sekitar abad 1200 ,yang berarti "kumpulan hal yang terkait bersamasama."dalam teknik sipil,Rangka batang (truss) adalah struktur yang terdiri dari gabungan batang yang bentuknya struktur segitiga dan terhubung satu sama lain,serta di bebani pada sendi-sendinya.

Sistem struktur rangka (truss) merupakan struktur kerangka yang di buat dengan menyambungkan elemen stuktur 
yang lurus dengan sambungan sendi di kedua ujungnya.Geometrik rangka yang paling sederhana adalah elemen yang ujungnya mempunyai perletakan sendi dan rol.Perletakan sendi dan rol pada elemen merupakan kekangan minimum yang diperlukan bagi keseimbangan gaya akibat bekerjanya beban luar.

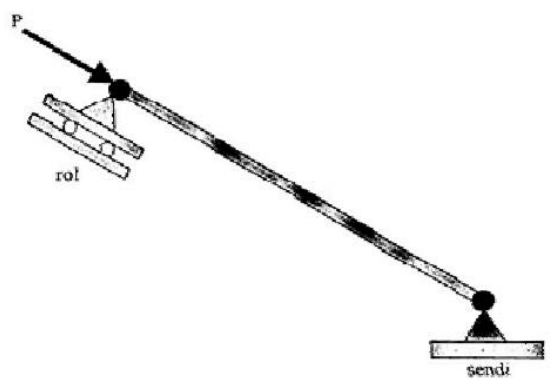

Gambar 7. 1 Batang dengan tumpuan rol dan tumpuan pin

Walaupun variasi beban yang bekerja pada sistem dapat berupa beban bentang dan beban titik tumpul, anggapan beban kerja rangka adalah beban yang selalu bekerja di titik kumpul.ini berarti beban bentang perlu di konversikan dulu dalam beben kerja terpusat ekivalen di titik kumpul.Pada geometri rangka yang paling sederhana seperti gambar di atas, hanya ada satu derajat kebebasan,sehingga hanya ada satu arah beban yang dapat dikerjakan.

Rangka dasar ini dapat di kembangkan menjadi rangka bidang dengan dua cara:

1) Penambahan elemen seperti gambar " $a$ " dengan tambahan perletakan rol pada ujung elemen tambahan,sehingga tetap terjaga syarat stabilitas sistem.

2) Menambah dua elemen yang saling berhubungan pada satu titik kumpul,sehingga stabilitas sistem tetap terjaga (gambar "b"). 


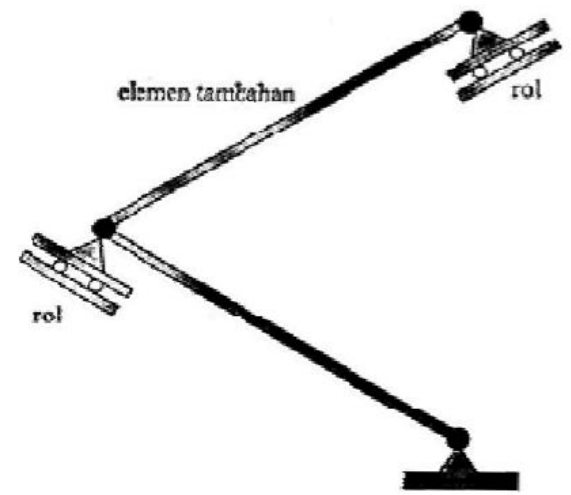

Gambar 7. 2 A. Sistem rangka 1

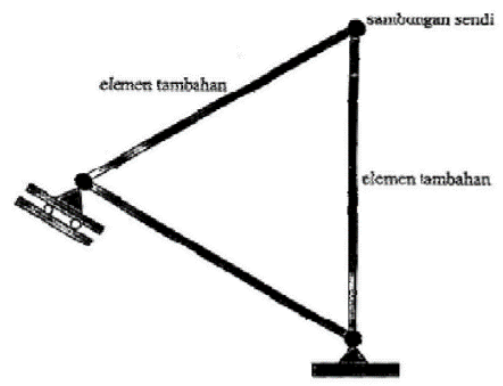

Gambar 7. 3 B. Sistem rangka 2

Bentuk-bentuk struktur Truss :

1. Rangka Bidang

Plane truss (rangka bidang) adalah truss yang elemen dan gabungan berada dalam suatu bidang 2 dimensi.ada dua bentuk dasar dari plane truss,yaitu:

a. Truss Traged atau Common Truss, bisa dibedakan dari bentuk segitiganya.tipe ini sering digunakan untuk konstruksi 
atap.beberapa tipe truss ini dinamai sesuai dengan konfigurasi web nya.ukuran elemen dan konfigurasi web pilihan berdasarkan bentang

b. Chamen Truss atau flat truss,biasanya digunakan untuk bangunan

c. Kombinasi dari dua bentuk tersebut adalah truss truncated,digunakan pada konstruksi atap pinggul

Secara skematika beberapa bentuk rangka bidangyang dirancang berdasarkansifat beban kerja adalah:

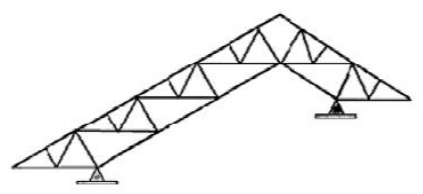

Gambar 7. 4 Rangka atap

Pada rangka atap,beban yang bekerja selain berat sendiri adalah beban komponen atap (penutup atap,kaso-kao,gordin) dan tekanan angin.

Baban hidup jembatan adalah berat kendaraan ;path menara air,berat air dan pada menara jaringan listrik berupa berat kabel,sedangkan di menara komunikasi berupa beban atena.

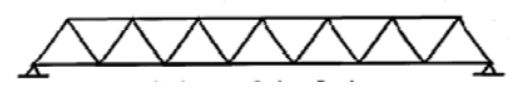

Gambar 7. 5 Rangka jembatan 

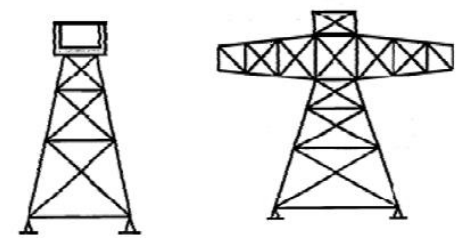

Gambar 7. 6 Rangka Menara

2. Space Truss (Rangka Ruang)

Adalah truss yang memiliki elemen-elemen dan joint-joint yang membentuk 3 dimensi. Bentuk dasar penyusun space truss adalah limas (tetrahedron). Dalam aplikasinya, ruang truss untuk atap dikembangkan dalam beberapa bentuk relevan sebagai berikut : 


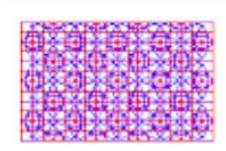

struktur pesawat
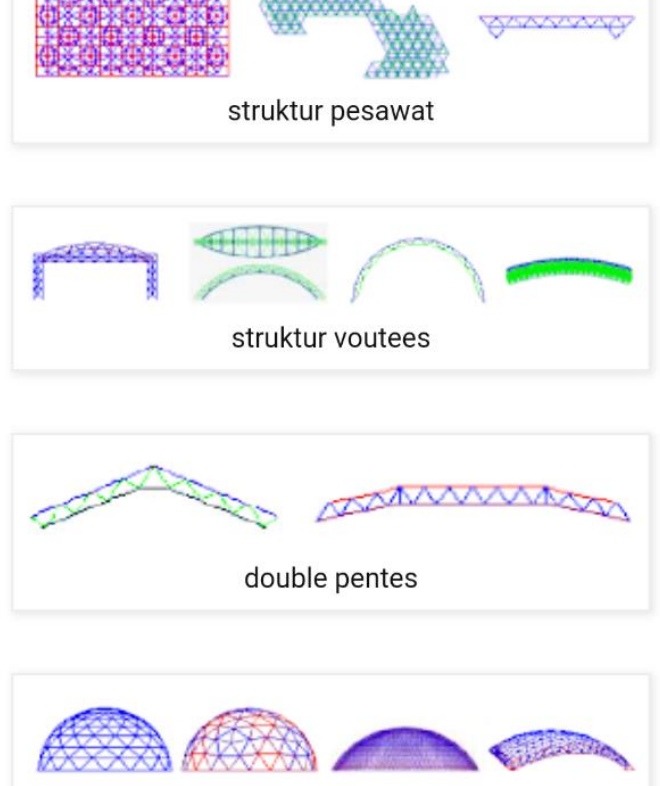

kubah

Gambar 7. 7 Beberapa contoh struktur

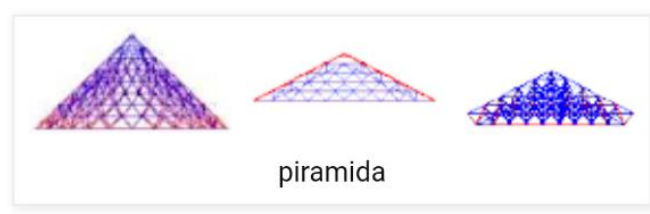

Gambar 7. 8 Rangka piramid

Seperti bentuk portal ruang, ruang rangka merupakan susunan (sesuai gambar dibawah) unsur elemen batang pada sistem ruang, tetapi sambungan unsur elemen batang pada kedua ujungnya bersifat sendi dan beban yang bekerja 
merupakan beban ekivalen terpusat pada setiap titik kumpul.

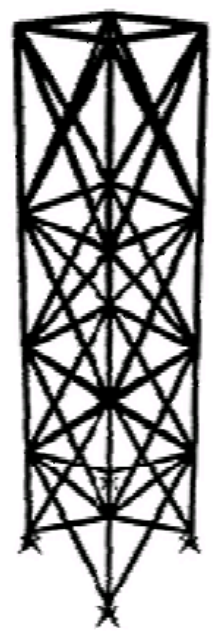

Gambar 7. 9 Struktur Portal ruang

\subsection{Truss sederhana}

Struktur yang dibentuk dari sebuah segitiga dasar yang dikenal dengan rangka batang sederhana atau yg disebut truss sederhana. Jika terdapat jumlah batang yang diperlukan lebih banyak untuk mencegah agar tidak runtuh, maka rangka batang tersebut menjadi statis tak tentu. Artinya rangka batang tersebut tidak dapat di analisa hanya menggunakan persamaan-persamaan keseimbangan statis saja .

Batang kelebihan yang tidak perlu untuk mempertahankan posisi setimbang disebut redundant. Stabilitas dari sebuah rangka batang juga tergantung pada posisi tumpuan yang tersedia. Secara umum kita dapat menyatakan bahwa stabilitas dari struktur harus di tumpu oleh sekurang-kurangnya 3 gaya reaksi, semuanya tidak boleh parallel ataupu konkuren. 


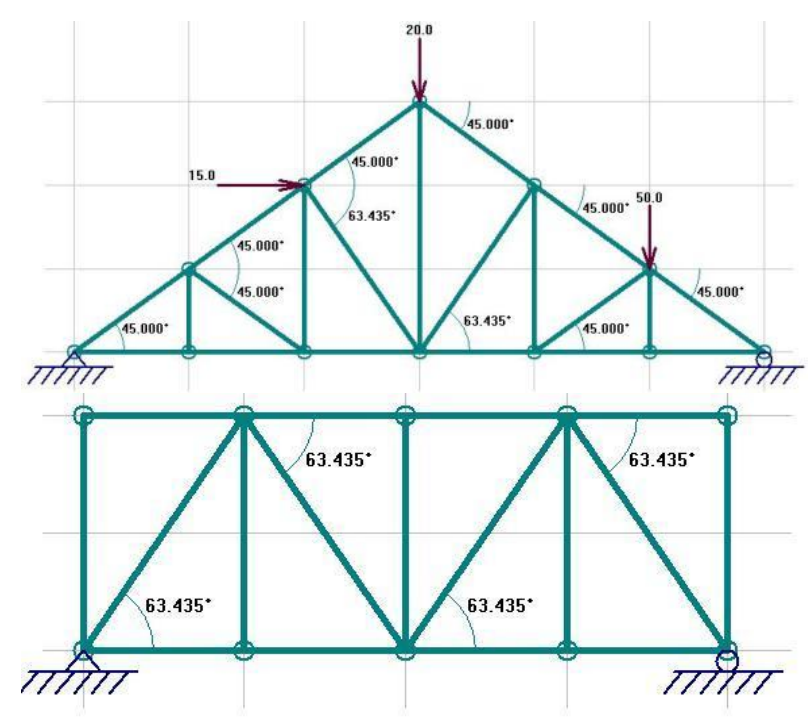

Gambar 7. 10 Truss

Stabilitas rangka batang dapat ditinjau dari stabilitas luar, yaitu reaksi perletakan tidak boleh bertemu di satu titik. Selain dari stabilitas luar,ada juga stabilitas dalam, yaitu rangka batang harus tersusun dari pola-pola segitiga. Struktur ada yg statis tertentu dan ada yang statis tak tentu, yang akan dibahas disini adalah statis tak tertentu.

Sarat dari struktur statis tertentu adalah jumlah gaya pada tumpuan struktur $=3$. Seperti gambar diatas ada satu tumpuan sendi dan ada satu tumpuan rol. Tumpuan sendi mempunyai dua gaya, yaitu gaya horizontal dan gaya vertikal (maksudnya yang sejajar dan tegak lurus), sedangkan tumpuan rol memiliki satu gaya, yaitu gaya vertikal. Maka bila di jumlahkan ada tiga gaya, sehingga struktur ini memenuhi syarat struktur statis tertentu.

Cara menghitung gaya pada batang, ada dua metode yang dikenal saat ini,yaitu metode buhul dan metode ritter. Sebagai contoh kita menggunakan metode titik buhul. Metode titik buhul cukup sederhana, tapi butuh ketelitian. Penyelesaiannya dimulai dengan menghitung reaksi perletakan. Lalu menghitung gaya vertikal dan horisontal dengan persamaan $\Sigma \mathrm{V}=0$ dan $\Sigma \mathrm{H}=0$. 


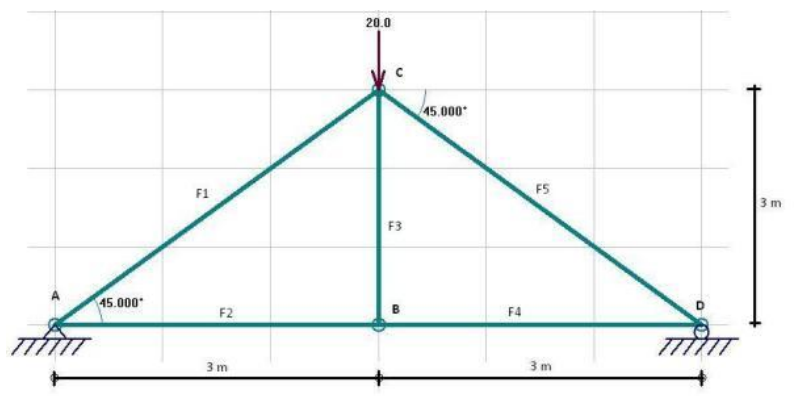

Gambar 7. 11 Trus sederhana

Langkah pertama adalah tentukan sudut antar batang, dan berikan nama pada setiap titik buhul dan tiap batang, ini untuk mempermudah perhitungan.

Langkah kedua adalah hitung reaksi perletakannya. Pada contoh ini gaya yang diberikan tepat di tengah sebesar 2020 kN, maka beban ini akan didistribusikan ke tumpuan masing-masing sebesar $10 \mathrm{kN}$. Sehingga $\mathrm{RAV}=10 \mathrm{kN}$ dan $\mathrm{RBV}=10 \mathrm{kN}$, sedangkan $\mathrm{RAH}=0$, karena tidak ada beban horizontal.

Langkah berikutnya adalah menghitung gaya pada batang disetiap titik buhul.

Pertama kita akan menghitung gaya pada batang di buhul $\mathrm{A}$

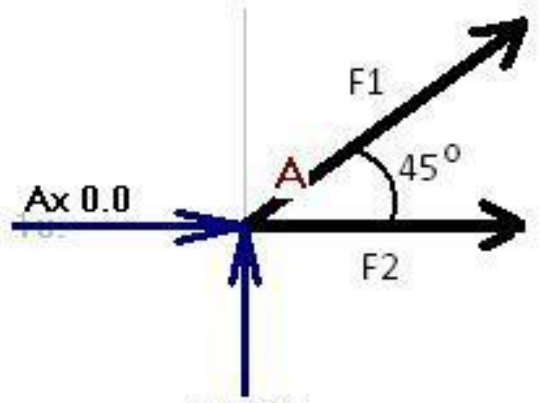

Ay 10.0

Gambar 7. 12 gaya-gaya pada titik $A$ 


$$
\begin{aligned}
& \Sigma V=0 \\
& R A V+F 1 \sin 45=0 \\
& 10=-F 1 \sin 45 \\
& -F 1=10 / \sin 45 \\
& F 1=-14.14 \mathrm{kN} \\
& \Sigma H=0 \\
& R A H+F 2+F 1 \cos 45=0 \\
& 0+F 2=-F 1 \cos 45 \\
& F 2=-(-14.14 \cos 45) \quad F 2=10 \mathrm{kN}
\end{aligned}
$$

Buhul B :

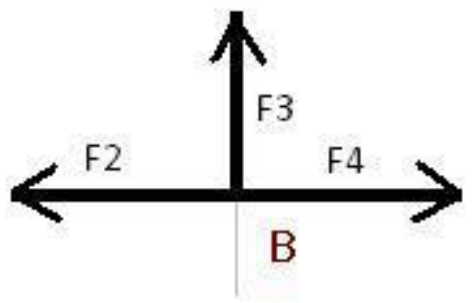

Gambar 7. 13 Gaya pada titik B

$\Sigma \mathrm{V}=0$

$\mathrm{F} 3=0$

$\Sigma \mathrm{H}=0$

F2-F4 = 0

$\mathrm{F} 2=\mathrm{F} 4$

$\mathrm{F} 4=10 \mathrm{kN}$

Buhul C: 


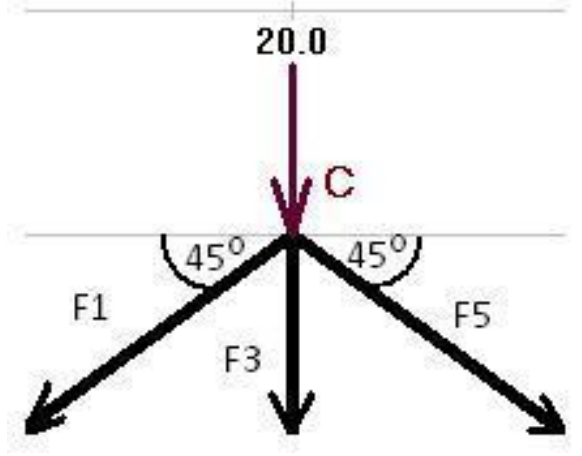

Gambar 7. 14 Gaya pada titik C

$\Sigma V=0$
$-20-F 3-F 1$ sin
$-20-0-(-14.14$
$-20-0+10=$
$F 5=-10 / \sin 45$
$F 5=-14.14 \mathrm{kN}$
$\Sigma H=0$
$-F 1 \cos 45+F$
$-10+10=0$
Jadi hasilnya :
$F 1=-14.14 \mathrm{kN}$
$F 2=10 \mathrm{kN}$
$F 3=0 \mathrm{kN}$
$F 4=10 \mathrm{kN}$
$F 5=-14.14 \mathrm{kN}$

7.3. Analisa truss dengan metode join

Cara keseimbangan titik buhul dan metode potongan. Kedua cara tersebut dapat dilakukan dengan secara grafis dan analitis. Cara pertama dengan grafis disebut dengan metode ceremona. Sedangkan cara kedua (Analitis) 
dilakukan dengan metode ritter, yang dilakukan dengan secara grafis dinamakan dengan metodecullman.

Tata cara perhitungannya adalah sebagai berikut:

1. Gaya diuraikan menjadi dua arah saling tegak lurus.

2. Arah gaya sebelum dan sesudah diketahui besar dan arahnya dianggap meninggalkan titik buhul, tandan aljabar plus (+) dan (-) tetap diikutsertakan.

3. Gaya batang tarik (meninggalkan titik buhul) (+), tekan (menuju titik buhul) (-).

4. Hitungan dilakukan pada titik buhul yang maksimum dua buah gaya yang belum diketahui.

Pada suatu rangka keseluruhan kontruksi serta titik simpul harus dalam keadaan seimbang dan tiap simpul di pisahkan satu sama lain. Setiap titik simpul akan seimbang akibat gaya luar yang bekerja dan gaya dalam yang ditimbulkan. Gaya luar dan gaya batang berpotongan dititik simpul.

Untuk menghitung gaya yang belum diketahui gigunaka persaman $\Sigma \mathrm{V}=0$ dan $\Sigma \mathrm{H}=0$.

Dari persamaa tersebut simpul yang akan dicari gaya batangnya harus hanya 2 atau 1 yang belum diketahui dianggap sebagai batang tarik.

Jadi tiap simpul dicari keseimbangannya satu persatu, sehingga seluruh kontruksi dapat diketahui gaya batangnya.

Contoh kontruksi rangka batang pada gambar dibawah ini. Cari gaya gaya batangnya. 


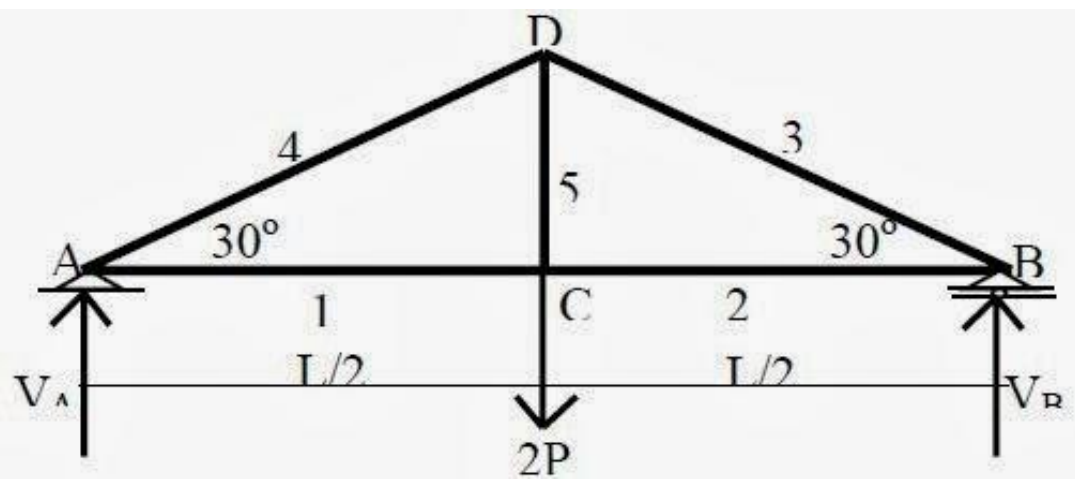

Gambar 7. 15 latihan penyelesain truss

Pertama tentukan kestabilan kontruksi dengan persamaan :

$2 s-m-r=0$

$\mathrm{S}=4, \mathrm{~m}=5, \mathrm{r}=3$

Maka diperoleh 2.4-5-3=0 Jadi kontruksi stabil.

Reaksi perletakan, menentukan secra analitis dengan

menggunakan keseimbangan momen pada salah stau titik tumpuan.

$$
\begin{aligned}
& \Sigma M_{B}=0 \rightarrow V_{A} \cdot L+2 P \cdot L / 2=0 \rightarrow V_{A}=P \\
& \Sigma M_{A}=0 \rightarrow-V_{B} \cdot L+2 P \cdot L / 2=0 \rightarrow V_{B}=P
\end{aligned}
$$

Pertama lihat simpul A, ada gaya reaksi VA diketahui arah menuju simpul, dan dua batang yang gayanya belum diketahui, yaitu batang 1 dan batang 4 . Misal b1 dan b4 Maka kedua batangnya meninggalkan simpul $A$. 


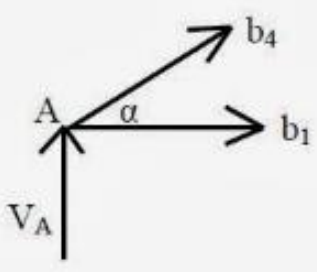

$$
\begin{aligned}
& \Sigma V=0 \\
& V_{A}+b_{4} \sin \alpha=0 \text {. } \\
& b_{4}=-\frac{V_{A}}{\sin \alpha}=-\frac{P}{\sin 30^{\circ}}=-2 P \\
& \Sigma H=0 \\
& b_{1}+b_{4} \cos \alpha=0 \\
& b_{1}=-b_{4} \cos \alpha=-(-2 P) \cos 30^{\circ}=1,7 P
\end{aligned}
$$

B4 negatif = batang tekan (menuju simpul)

B1 positif = batang tarik ( meninggalkan simpul)

Lihat simpul c, ada gaya 2P dan gaya batang b1 sudah diketahui ( meninggalkan simpul) dan ada batang yang gaya batangnya belum diketahui, yaitu gaya batang 5 dan 2 misalkan $5=$ b5 $2=$ b2 Maka batangnya arah meninggalkan simpil C.

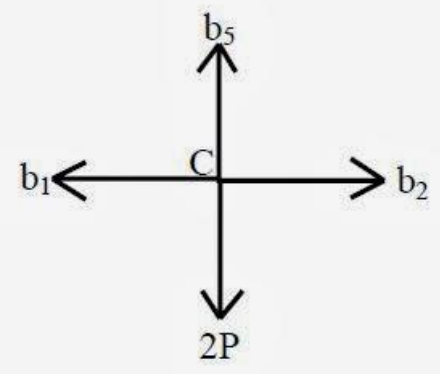

$$
\begin{aligned}
& \Sigma V=0 \\
& -2 P+b_{5}=0 . \\
& b_{5}=2 P \\
& \Sigma H=0 \\
& -b_{1}+b_{2}=0 \ldots \\
& b_{2}=b_{1}=1,7 P
\end{aligned}
$$

B5 dan b2 positif = batang tarik (maninggalkan simpul)

Lalu lihat simpul D, gaya batang b5 dan b4 sudah diketahui, b5 meninggalkan simpul dan b4 menuju simpul, satu batang yang gayanya belum diketahui. Yaitu 3 misal 3 = b3.

Maka batangnya tarik dengan arah meninggalkan simpul D. 


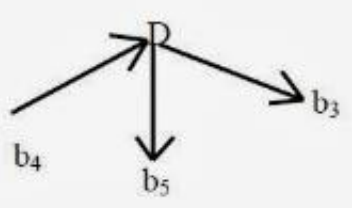

$$
\begin{aligned}
& \Sigma V=0 \\
& \left.-b_{5}+b_{4} \sin \alpha-b_{3} \sin \alpha=0 \ldots .6 .2 g\right) \\
& b_{3}=\frac{-b_{5}+b_{4} \sin \alpha}{\sin \alpha} \\
& b_{3}=\frac{-(2 P)+(2 P) \sin 30^{\circ}}{\sin 30^{\circ}}=-2 P \\
& \Sigma H=0 \\
& \left.b_{4} \cos \alpha+b_{3} \cos \alpha=0 \ldots \ldots \ldots \ldots .6 .2 h\right) \\
& (2 P) \cos 30^{\circ}+(-2 P) \cos 30^{\circ}=0
\end{aligned}
$$

B3 negatif = batang tekan ( menuju simpul)

Semua gaya batang sudah diketahui, untuk membuktikan keseimbangan pada semua titik simpul, perlu dilihat simpul B ada gaya reaksi VB yang arahnya menuju simpul gaya batang b2 arahnya meninggalkan simpul b3 menuju simpul.

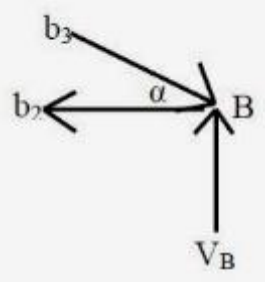

$$
\begin{aligned}
& \Sigma V=0 \\
& V_{B}-b_{3} \sin \alpha=0 \\
& P-(2 P) \sin 30^{\circ}=0 \\
& \Sigma H=0 \\
& -b_{2}+b_{3} \cos \alpha=0 \ldots \ldots \ldots \ldots \ldots \ldots \ldots \ldots \ldots \\
& -(1,7 P)+(2 P) \cos 30^{\circ}=0
\end{aligned}
$$

Dari persamaan keseimbangan gaya vertikal dan horizontal, terbukti bahwa gaya batang pada simpul B sudah seimbang. Setelah semua titik keseimbangan dilihat dapat diringkas besarnya gaya batang seluruh rangka. 


\begin{tabular}{|c|c|c|}
\hline \multirow{2}{*}{ No Batang } & \multicolumn{2}{|c|}{ Gaya-Gaya Batang (satuan gaya) } \\
\cline { 2 - 3 } & Tarik (+) & Tekan (-) \\
\hline $\mathrm{b}_{1}$ & $\underline{1,7 \mathrm{P}}$ & - \\
\hline $\mathrm{b}_{2}$ & $\underline{1,7 \mathrm{P}}$ & - \\
\hline $\mathrm{b}_{3}$ & - & $2 \mathrm{P}$ \\
\hline $\mathrm{b}_{4}$ & - & $2 \mathrm{P}$ \\
\hline $\mathrm{b}_{5}$ & $2 \mathrm{P}$ & - \\
\hline
\end{tabular}

\section{Cari gaya - gaya batang dengan Metode Titik Buhul}

\section{Titik Buhul A}

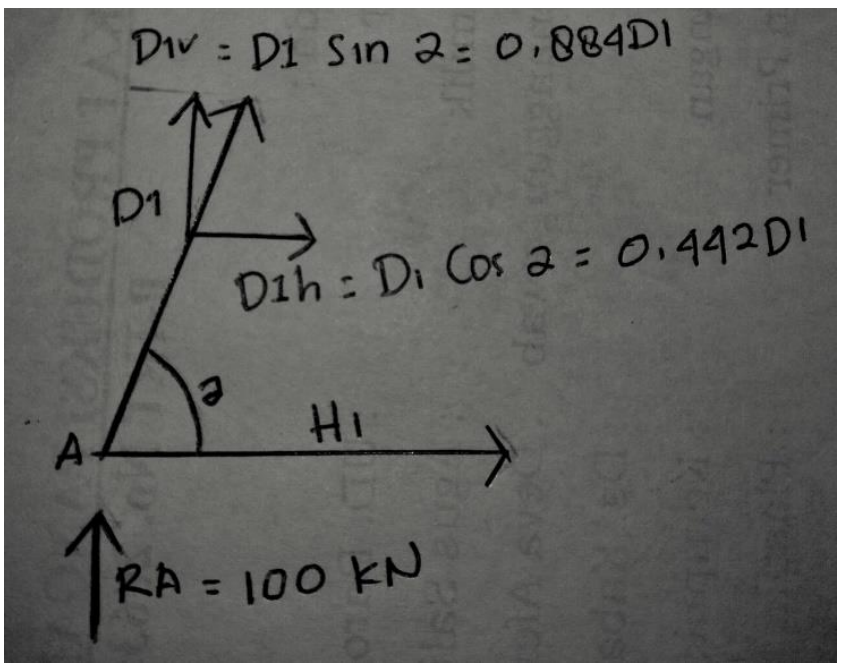

Gambar 7. 16 Gaya pada buhul A

Untuk batang diagonal atau Batang Miring perlu dicari gaya dalam arah vertikal dan horizontalnya terlebih dahulu. Seperti pada gambar di atas, batang D1 dibuat dipecah menjadi D1v (arah vertikal) dan D1h (arah horizontal).

Yang perlu diketahui arah horizontal dikali dengan cosinus dan arah vertikal dikali dengan sinus. Titik pada bagian batang yang belum diketahui maksimal 2 batang. Sehingga :

$\mathrm{D} 1 \mathrm{v}=\mathrm{D} 1 \sin \mathrm{a}=0,884 \mathrm{D} 1$

$\mathrm{D} 1 \mathrm{~h}=\mathrm{D} 1 \cos \mathrm{a}=0,442 \mathrm{D} 1$ 
Tinjau keseimbangan gaya vertikal

$\mathrm{D} 1 \mathrm{v}+\mathrm{RA}=0$

$0,884 \mathrm{D} 1+100=0$

$D 1=-(100 / 0,884)=-113,122 \mathrm{Kn}$

Tinjau keseimbangan gaya gaya horizontal

$\mathrm{D} 1 \mathrm{~h}+\mathrm{H} 1=0$

$0,442 \times(-113,112)+\mathrm{H} 1=0$

$\mathrm{H} 1=50 \mathrm{kN}$

Titik tinjau

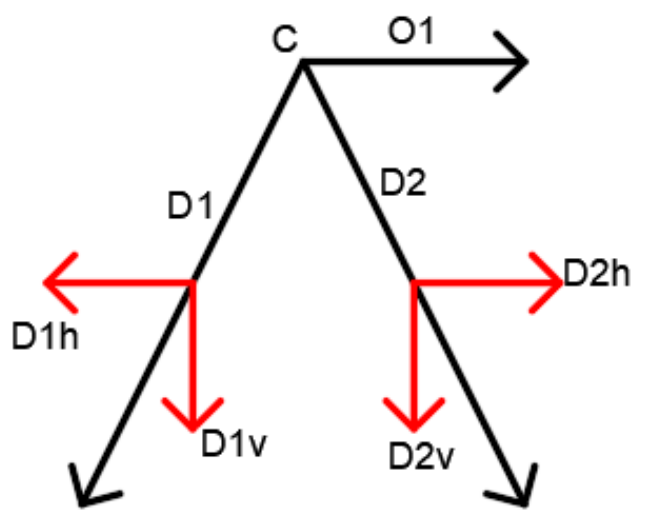

Buhul C

Gambar 7. 17 Digram gaya

$\mathrm{D} 2 \mathrm{v}=\mathrm{D} 2 \sin \mathrm{a}=0,884 \mathrm{D} 2$

$\mathrm{D} 2=\mathrm{D} 2$ coa $\mathrm{a}=0,442 \mathrm{D} 2$

Yang telah diketahui

$\mathrm{D} 1 \mathrm{v}=\mathrm{D} 1 \mathrm{sin} \mathrm{a}=0,884 \mathrm{D} 1=-100 \mathrm{kN}$

$D 1 h=D 1 \cos a=0,442 D 1=-50 K n$

Tinjau keseimbangan gaya gaya vertikal

$-D 1 v-D 2 v=0$

$100-0,884 \mathrm{D} 2=0$

D2 $=100 / 0,884=113,112 \mathrm{Kn}$

Tinjau keseimbangan gaya gaya horizontal 


$$
\begin{aligned}
& -D 1+O 1=D 2 h=0 \\
& -50+O 1+0,442 D 2=0 \\
& 50+01+50=0 \\
& O 1=-100 \mathrm{kN}
\end{aligned}
$$

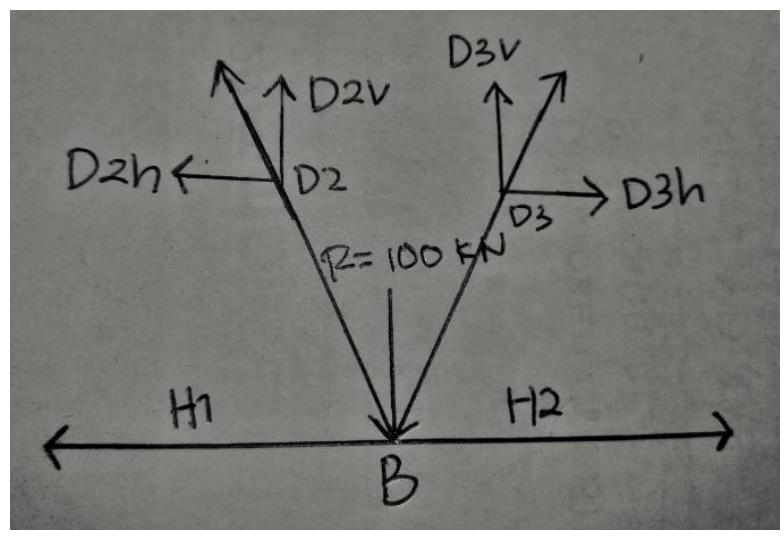

Gambar 7. 18 Gaya buhul C

$\mathrm{D} 3 \mathrm{v}=\mathrm{D} 3 \sin \mathrm{a}=0,884 \mathrm{D} 3$

$\mathrm{D} 3 \mathrm{~h}=\mathrm{D} 3 \cos \mathrm{a}=0,442 \mathrm{D} 3$

Yang telah diketahui :

$\mathrm{D} 1 \mathrm{v}=\mathrm{D} 1 \sin \mathrm{a}=0,884 \mathrm{D} 1=-100 \mathrm{kN}$

$D 1 h=D 1 \cos a=0,442 D 1=-50 k N$

$\mathrm{D} 2 \mathrm{v}=\mathrm{D} 2 \sin \mathrm{a}=0,884 \mathrm{D} 2=100 \mathrm{kN}$

$\mathrm{D} 2 \mathrm{~h}=\mathrm{D} 2 \cos \mathrm{a}=0,442 \mathrm{D} 2=100 \mathrm{kN}$

Tinjau keseimbangan gaya vertikal

$-P+D 2 v+D 3 v=0$

$-100+0,884 \mathrm{D} 2+0,884 \mathrm{D} 3=0$

$-100+100+0,884 \mathrm{D} 3=0$

$\mathrm{D} 3=0 \mathrm{kN}$

Tinjau keseimbangan gaya horizontal

$-\mathrm{H} 1+\mathrm{H} 2-\mathrm{D} 2 \mathrm{~h}+\mathrm{D} 3 \mathrm{~h}=0$

$-50+\mathrm{H} 2-50+0=0$

$\mathrm{H} 2=100 \mathrm{kN}$ 
Tabel :

\begin{tabular}{|c|c|c|}
\hline Nama batang & Batang tarik & Batang tekan \\
\hline $\mathrm{H} 1=\mathrm{h} 3$ & $50 \mathrm{kN}$ & \\
\hline $\mathrm{H} 2$ & $100 \mathrm{kN}$ & $-113,112 \mathrm{kN}$ \\
\hline $\mathrm{D} 1=\mathrm{D} 6$ & & \\
\hline D2=D5 & $113,112 \mathrm{kN}$ & 0 \\
\hline D3=D4 & 0 & $-100 \mathrm{kN}$ \\
\hline 01=02 & & \\
\hline & & \\
\hline
\end{tabular}

\subsection{Analisa Truss Dengan Metode Section}

1. Metode ini digunakan bila :

Ingin mengetahui gaya salah satu batang dengan cepat biasanya untuk mengontrol hasil perhitungan dr metode lain.

2. Bila dalam method of Joints hanya menggunakan 2 persamaan keseimbangan, maka dalam method ini menggunakan 3 persamaan keseimbangan $(\Sigma \mathrm{H}=0, \Sigma \mathrm{V}=0, \Sigma \mathrm{M}$ $=0$ )

Langkah Penyelesaian

1. Cek stabilitas rangka batang dengan rumus $=2 j-3$ ( $n=j u m l a h$ batang, j=jumlah point)

2. Menentukan gaya-gaya reaksi tumpuan

3. Buat potonangan yang melalui elemen yang akan dicari besarnya gaya sehingga menghasilkan 2 free body

4. Meninjau setiap free body tersebut berada dalam keseimbangan translasi

$(\Sigma \mathrm{V}=0, \Sigma \mathrm{H}=0, \Sigma \mathrm{M}=0)$ 
Contoh Soal

Tentukan besar reaksi perletakan dan daftar gaya batang untuk struktur rangka batang berikut:

\section{Memeriksa kestabilan struktur}

$$
m=2 . j-313=2 * 8-3=13 \text { Ok! }
$$

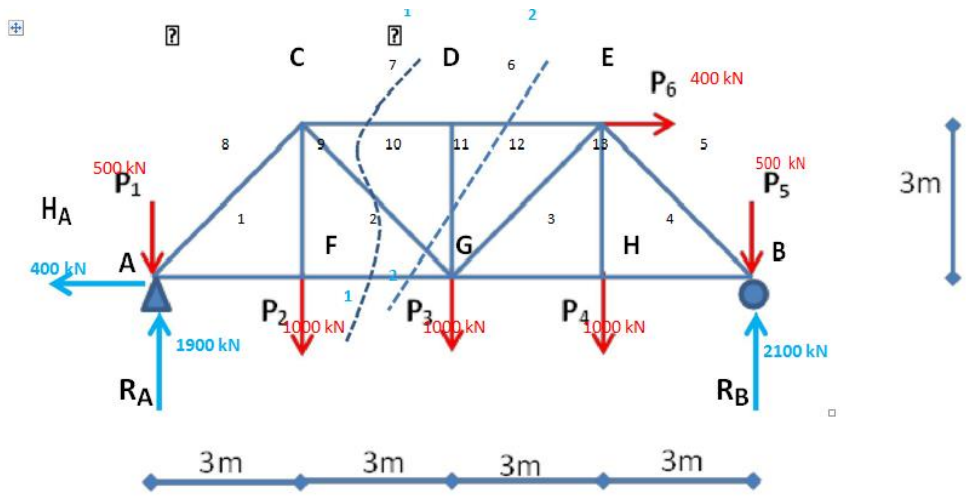

POTONGAN 1-1

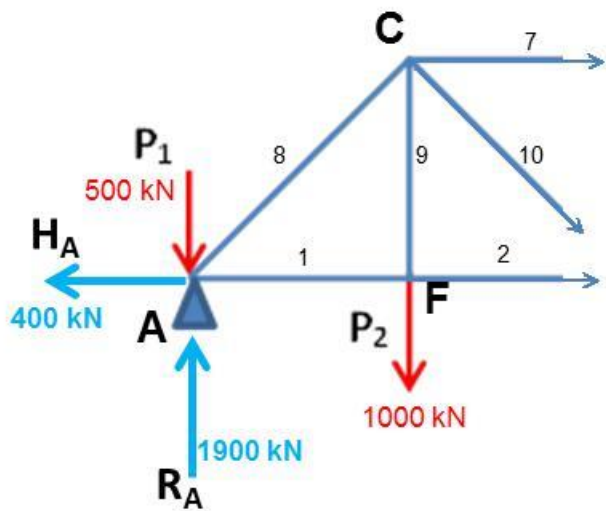




\section{$\sum M c=0$}

Ra . 3- P1 . $3+$ Ha. $3-\mathrm{S}_{2} .3=01900.3-500.3+400.3=\mathrm{S}_{2} .3$

$\mathrm{S}_{\mathbf{2}}=1800 \mathrm{kN}$ (Tarik)

$\Sigma \mathbf{V}=\mathbf{0}$

$\mathrm{Ra}-\mathrm{P} 1-\mathrm{P} 2-\mathrm{S}_{10} \sin 45=0$

$1900-500-1000-S_{10} \sin 45=0 S_{10}=566 \mathbf{k N}($ Tarik $)$

$\sum H=0$

- $\mathrm{Ha}+\mathrm{S}_{10} \cos 45+\mathrm{S}_{2}+\mathrm{S}_{7}=0$

$-400+400+1800+S_{7}=0 S_{7}=-1800$ kN (Tekan)

\section{POTONGAN 2-2}

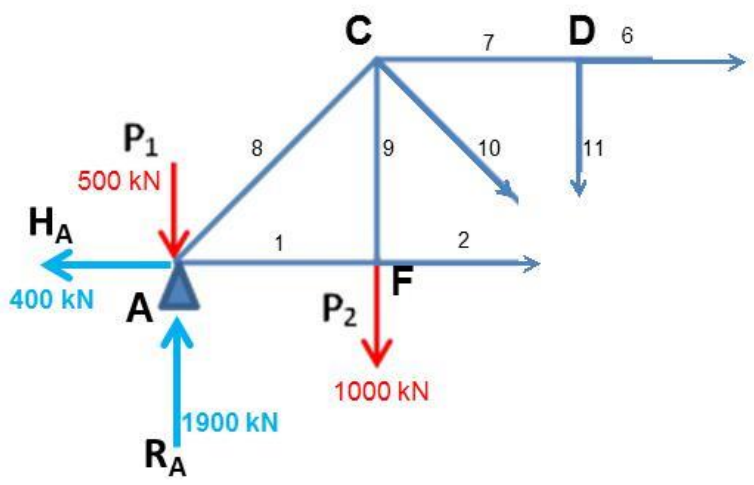

Gambar 7. 20 Potongan 2-2 


$$
\begin{aligned}
& \sum M g=0 \\
& S_{6}=-1800 \mathrm{kN} \text { (tekan) } \\
& \sum \mathrm{V}=\mathbf{0} \\
& \mathrm{S}_{11}=\mathbf{0} \mathbf{~ k N}
\end{aligned}
$$




\subsection{Truss komplek}

Merupakan struktur elemen terhubung atau gabungan yang membentuk unit segitiga. Unsur-unsur yang terhubung (biasanya lurus) dapat ditekankan dari ketegangan, kompresi, atau kadangkadang baik dalam respons terhadap beban dinamis. Sifat Truss memungkinkan analisis struktur menggunakan beberapa asumsi dan penerapan hukum Newton tentang gerak sesuaidengan cabang fisika yang dikenal sebagai statika. Untuk keperluananalisis, gulungan diasumsikan pin bersendi dimana komponen lurusbertemu. Asumsi ini berarti bahwa anggota truss (chords, vertikal dandiagonal) akan bertindak hanya dalam ketegangan atau kompresi. Sebuah analisis lebih kompleks diperlukan di mana sendi kaku memaksakanbeban lentur signifikan terhadap unsur-unsur, seperti dalam trussVierendeel.

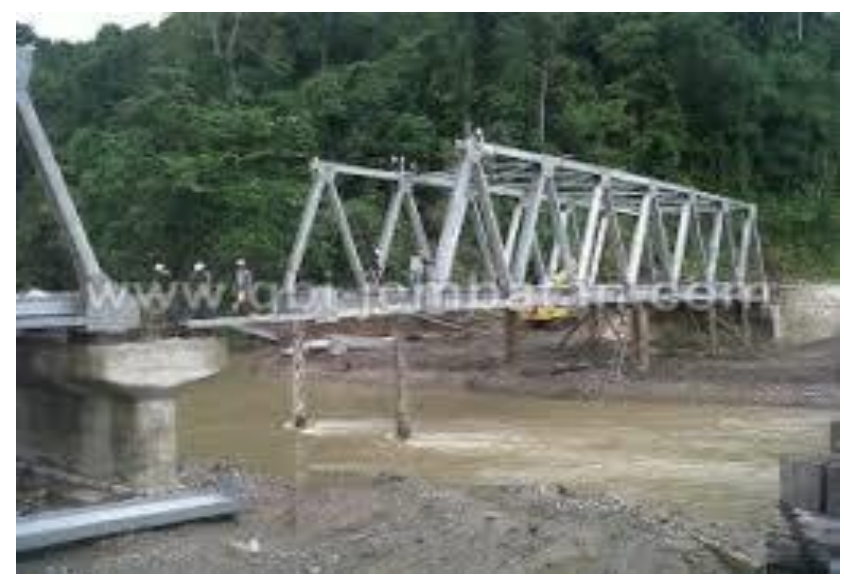

Gambar 7. 21 Truss jembatan

Di jembatan diilustrasikan dalam kotak info di bagian atas.Anggota vertikal dalam ketegangan, anggota yang lebih rendah horisontaldalam ketegangan, geser, dan lentur, anggota luar diagonal dan atas adalah dalam kompresi, sedangkan diagonal batin dalam ketegangan. Para anggota vertikal pusat menstabilkan 
anggota kompresi atas,mencegah dari tekuk. Jika anggota atas adalah cukup kaku maka elemen vertikal ini dapat dihilangkan. Jika akord yang lebih rendah (anggotahorizontal truss) cukup tahan terhadap lentur dan geser, elemen vertikalluar dapat dihilangkan, tetapi dengan kekuatan tambahan ditambahkan keanggota lain sebagai kompensasi.Kemampuan untuk mendistribusikan kekuatan dalam berbagaicara telah menyebabkan berbagai macam jenis truss jembatan. Beberapajenis mungkin lebih menguntungkan bila kayu digunakan untuk elemenkompresi sementara jenis lain mungkin lebih mudah untuk mendirikandalam kondisi situs tertentu, atau ketika keseimbangan antara tenagakerja, mesin dan biaya bahan memiliki proporsi yang menguntungkantertentu. Dimasukkannya unsur yang ditunjukkan sebagian besarkeputusan rekayasa berdasarkan ekonomi, menjadi keseimbangan antarabiaya bahan baku, fabrikasi off-site, transportasi komponen, di tempat ereksi, ketersediaan mesin dan biaya tenaga kerja. 


\subsection{Analisa frame}

Truss frame, atau rangka batang, adalah struktur yang dibentuk dari susunan batang linier yang digabung dan membentuk pola-pola segitiga. Sistem struktur rangka batang banyak digunakan pada rangka jembatan, ataupun rangka kuda-kuda bangunan. Rangka batang menjadi populer karena susunannya yang mudah dikerjakan karena terdiri dari batang-batang linier, dengan efisiennya yang tinggi, cukup kokoh, dan stabil. Kunci dari struktur rangka batang adalah bentuknya yang segitiga (triangulasi), dimana bentuk ini kuat untuk menahan gaya lateral dalam bangunan bertingkat tinggi.

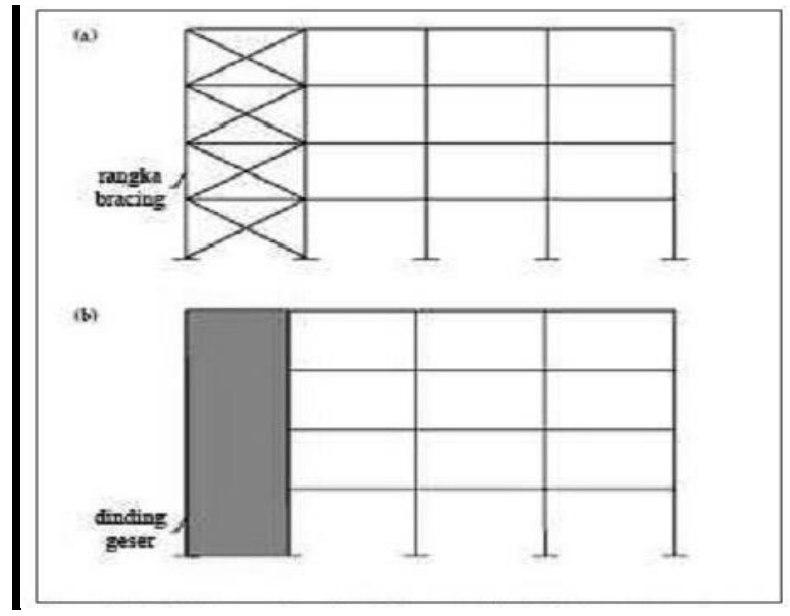

Gambar 7. 22 Perbandingan sistem struktur rangka batang dengan dinding geser.

Meskipun sistem struktur ini terdiri dari elemen-elemen Truss yang lurus, kestabilannya tetap terjaga dan kuat karena geometri segitiganya. Beban yang terjadi ditumpu oleh sambungan sendi tiap rangka. Jadi, kunci utama pada struktur truss adalah sambungan sendinya. 
Tabel 7. 1 Spesifikasi dan Perbedaan Antarabeberapa Truss Bridge:

\begin{tabular}{|l|c|c|l|}
\hline \multicolumn{1}{|c|}{ Tipe } & Konfigurasi Rangka & Material & \multicolumn{1}{c|}{ Keterangan } \\
\hline Pratt & Baja & $\begin{array}{l}\text { Sering digunakan lebih banyak dimasa } \\
\text { lampau dari pada tipe-tipe rangka } \\
\text { lainnya, bentang maksimal 200 ft }\end{array}$ \\
\hline Howe & & Baja & $\begin{array}{l}\text { Sering digunakan dimasa lampau tetapi } \\
\text { sangat sedikit digunakan sekarang }\end{array}$ \\
\hline Parren & & Baja & $\begin{array}{l}\text { Sangat umum, untuk bentang maksimal } \\
200 \mathrm{ft}\end{array}$ \\
\hline Baltimore & & Baja & $\begin{array}{l}\text { Untk bentang diatas 180 ft atau 200ft } \\
\text { sampai 350 } \mathrm{ft} \text { atau 360 ft, lebih ekonomis }\end{array}$ \\
\hline "K" truss & & Baja & Digunakan untuk bentang diatas 300 ft \\
\hline
\end{tabular}

Salah satu bangunan menggunakan sistem truss yang sering dijumpai adalah jembatan rangka batang (truss bridge). Jika dibandingkan dengan jembatan sederhana, jembatan rangka batang dapat memberikan nilai kekakuan yang lebih tinggi untuk panjang bentang yang sama. Selain itu, jumlah material yang diperlukan jembatan rangka batang lebih sedikit untuk menghasilkan kekakuan yang sama besar. Hal ini dimungkinkan karena konfigurasi rangka batang yang efisien sebab gaya-gaya yang bekerja didukung secara aksial oleh batang-batang yang terdapat dalam struktur tersebut, sehingga kekuatan aksial batang-batang tersebut dapat dimanfaatkan secara maksimal.

Namun, jembatan rangka batang hanya efisien jika digunakan untuk bentang sedang (misalnya jembatan truss tipe Warren yang dapat mencapai panjang 60 
meter), karena semakin panjang jembatan, maka tinggi jembatan yang diperlukan

juga bertambah untuk menjaga nilai kekakuannya. Selain panjang dan tinggi

jembatan yang bertambah, luas penampang profil baja yang digunakan pun juga semakin besar untuk menjaga nilai kelangsingan elemen-elemen strukturnya, ha lini menyebabkan berat sendiri struktur juga bertambah. Jika berat sendiri struktur tersebut terlalu besar, maka jembatan tidak lagi mampu mendukung berat sendirinya. Oleh karena itu, diperlukan optimasi untuk menghasilkan struktur yang efisien. Hal yang sama juga berlaku untuk struktur lain yang panjangnya lebih besar daripada tingginya, misalnya struktur kuda-kuda.

Baja merupakan material yang sering digunakan untuk sistem rangka batang, antara lain karena memiliki kuat tarik tinggi, modulus elastis yang besar sehingga memberikan nilai kekakuan yang tinggi, dan mudah digunakan sebagai material yang akan dirakit di lapangan.

Berbagai jenis profil baja telah tersedia di pasaran, profil-profil tersebut telah

dicetak menurut bentuk dan ukuran tertentu serta siap untuk dirangkai membentuk

berbagai struktur. Contoh beberapa bentuk penampang profil baja yang tersedia di

lapangan dapat dilihat pada Gambar 1.3. Profil-profil tersebut umumnya telah

disediakan dengan spesifikasi tertentu oleh pabrik/penyedia material. 

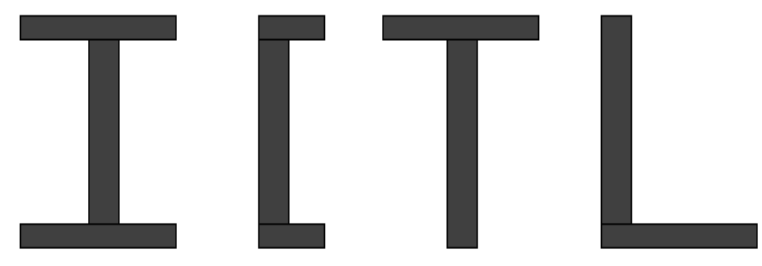

Gambar 7. 23 Tipe penampang profil baja

Jika diberi gaya luar, maka batang-batang yang terdapat dalam system rangka batang akan mengalami gaya-gaya batang berupa gaya tekan atau gaya tarik, sehingga dalam perancangan struktur rangka batang, batang-batang umumnya dihitung berdasarkan ketentuan untuk kondisi batang tekan dan batang tarik. Seiring perkembangan jaman, peraturan yang digunakan untuk perhitungan struktur tersebut, termasuk peraturan tentang desain dan analisis baja, terus berkembang karena perkembangan ilmu pengetahuan dan teknologi,

perkembangan di lapangan, maupun pengaruh dari perkembangan peraturan di dalam maupun luar negeri. Peraturan-peraturan tersebut wajib dipatuhi dalam mendesain dan menganalisis bangunan di setiap negara sesuai dengan masa berlakunya.

Contoh idealisasi sistem rangka batang dapat dilihat pada Gambar 1.1. Rangka batang 2 dimensi umumnya terdiri dari bagian atas (top chord), bagian bawah (bottom chord) dan bagian tengah yang biasa disebut dengan web. Struktur tersebut umumnya didesain agar stabil (tidak bergerak), aman (tidak runtuh atau membahayakan pengguna), dan nyaman (defleksi yang terjadi tidak terlalu besar). 


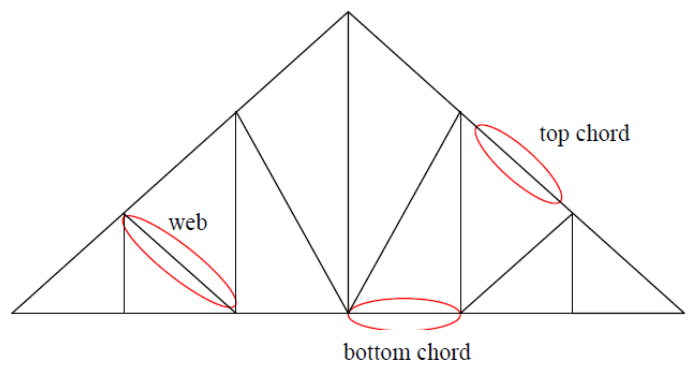

Gambar 7. 24 Idealisasi sistem rangka batang

Saat ini, rangka batang merupakan sistem struktur yang banyak digunakan dalam berbagai bangunan karena memiliki beberapa kelebihan antara lain kaku dalam menahan beban dan sederhana dalam analisis strukturnya.

Contoh dari bangunan yang menggunakan sistem truss yaitu jembatan, kuda-kuda, ataupun menara.

Persyaratan umum untuk rangka batang tersusun setinggi tingkat (the story-deep trusses) adalah membentang dalam arah transversal dari dimensi gedung, menopang beban gravitasi secara langsung, dan menyediakan ketahanan yang cukup untuk beban lateral (Scalzi 1986).Trussharus menyediakan suatu bukaan (opening) dekat pusat bentang untuk koridor dengan perbandingan lebar dan

ketinggian yang cukup. Bagian tepi (atas dan bawah) atau chord dari

trussseharusnya disesuaikan dengan lebar minimum sayap (flens), dengan tujuan untuk mendapatkan dinding dengan ketebalan minimum dan cukup untuk

menyediakan dudukan bagi sistem lantai.

Berdasarkan pengalaman proyek pembangunan Resort International Hotel 
Hassler 1986), sistem struktur staggered trussdilaksanakan secara bertahap lantai per lantai, karena ketidakstabilan yang diakibatkan oleh sistem lantai yang perletakannya berbeda, ujung yang satu terletak pada tepi bawah truss, sedangkan ujung yang lain terletak pada tepi atas trussTower crane merupakan salah satu alat berat yang wajib digunakan dengan pemilihan jenisnya berdasarkan ketinggian gedung, jangkauan dan kapasitas (beban ambil) untuk seluruh area lantai. Untuk gedung dengan jumlah lantai hingga 20 tingkat cukup menggunakan tower crane self-supported(model truk atau cat-mounted). Untuk gedung yang memiliki jumlah lantai lebih dari 20 tingkat perlu menggunakan external climbing craneyang disupportoleh menara baja dan dihubungkan dengan sistem struktur gedung setiap interval ketinggian 75 feet.

Berikut tahap-tahap pelaks anaan konstruksi staggered truss yang harus

Diperlihatkan untuk menciptakan stabilitas struktur.

1.Pemasangan kolom

2.Pemasangan spandrel beams untuk mengikat kolom-kolom sepanjang sumbu kuat 3.Pemasangan rangka batang baja (steel trusses)

4.Sambungan tepi bawah sebaiknya dibaut kencang penuh setelah beban mati ditambah dari sistem lantai.

5.Pembautan dengan baut mutu tinggi

6.Pembautan pelat (sebagai pengganti pengelasan pelat) pada truss. Grouting bertujuan menciptakan sistem bracing, acuan kerja dan lainlain di antara truss, bahkan grouting adalah kunci jointsuntuk dapat memberikan pembagian gaya geser pada pelat lantai yang telah disebutkan sebelumnya. 
Konsep dasar sistem staggered truss yaitu perilaku keseluruhan kerangka (frame) sebagai balok kantilever ketika sistem diberi beban lateral (Scalzi 1971). Dalam konteks ini, seluruh kolom yang terletak pada sisi eksterior dari gedung berfungsi sebagai sayap balok, sementara truss yang membentang dalam arah transversal pada keseluruhan lebar di antara kolom berfungsi sebagai badan dari balok kantileve.

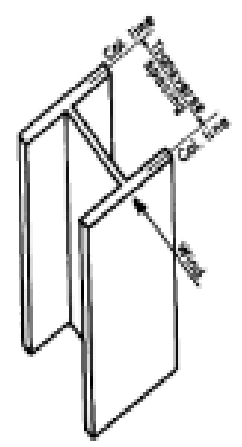

Gambar 7. 25 Sistem staggered truss diibaratkan sebagai kantilever vertikal (Scalzi, 1971)

Dengan kolom hanya pada sisi eksterior dari gedung dan biasanya kolom interior dihilangkan, maka sistem staggered truss memberikan suatu bentang lebar yang bebas kolom. Pengaturan bergantian dari rangka batang tersusun setinggi lantai

(floor-deep trusses) terletak pada level-level alternatif garis kolom yang berdekatan, yang mengijinkan bentang pelat lantai adalah sejarak kedua kolom yang menjadi tumpuan truss. Sehingga sistem tersebut menyediakan kebebasan pengaturan fungsi lantai bagi arsitek. 


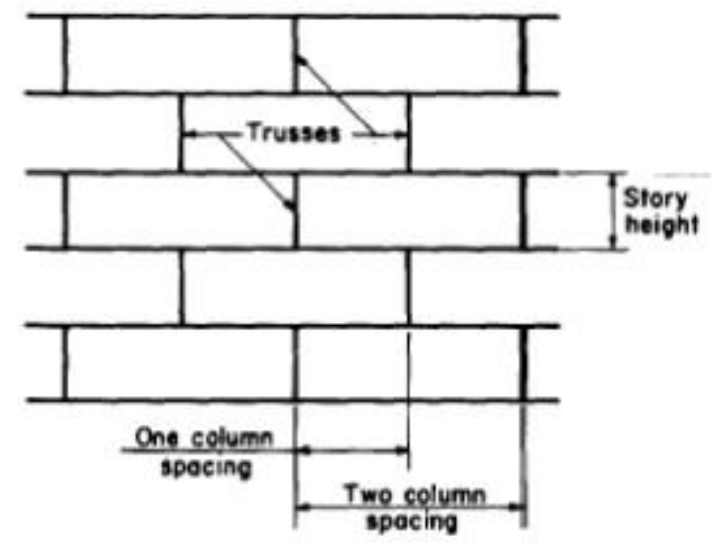

Gambar 7. 26 Pola bergantian truss pada sistem struktur

Aksi kantilever dari sistem truss adalah dua bidang (doubleplanar) yang menyebabkan beban-b

Jembatan Trus atau truss Bridge hanya memiliki perbedaan padadesain rangka ,batang yang menerima tekanan dan batang menerimategangan beberapa desain dari truss adalah hasil dari pengembangan truss itu sendiri seperti pada howe dan pratt truss dan warren dan bal eban lateral dapat mengurangi momen lentur yang terjadi

pada kolom. Orientasi badan kolom adalah tegak lurus dengan truss, sehingga

tekuk lokal karena hubungan dengan ujung tepi truss dapat diabaikan. Diperhatikan pula, orientasi sumbu kuat dari penampang melintang kolom juga harus tersedia untuk sistem kerangka Sistem staggered truss dapat dijadikan salah satu alternatif struktur bentang lebar pada gedung bertingkat dengan pertimbangan sebagai berikut:

1. Kolom memiliki momen lentur yang relatif kecil dibandingkan sistem portal karena adanya aksi kantilever dari sistem double-planarkerangka.

2. Kolom-kolom yang diorientasikan dalam sumbu kuat dapat bermanfaat untuk menahan gaya lateral dalamarah 
longitudinal gedung. Staggered truss dengan panjang lebih dari $15 \mathrm{~m}$ selain bermanfaat untuk menahan gaya lateral dalam arah transversal gedung, juga bermanfaat memberikan keleluasaan pengaturan fungsi ruang bagi arsitektural.

3. Lantai membentang pada lebar bentang yang pendek, yang disediakan oleh bentang spasi dua kolom atau dua truss. Maka, tebal pelat lantai dapat dibuat seminimal mungkin.

4. Bentang area terbuka yang sangat lebar untuk parkir atau tempat berkumpul banyak orang adalah dimungkinkan pada level lantai $\mathrm{p}$ e $\mathrm{r} \mathrm{t}$ am a, $\mathrm{k}$ a $\mathrm{r}$ e $\mathrm{n}$ a $\mathrm{k}$ olo $\mathrm{m}-\mathrm{k}$ o lo $\mathrm{m}$ berlokasi hanya pada sisi luar gedung.

5. Drift(simpangan antar tingkat) yang terjadi adalah kecil , karena keseluruhan frameberperilaku sebagai trusskaku dengan beban aksial langsung bekerja pada seluruh elemen struktur.

6. Struktur baja yang relatif ringan dapat dicapai jika menggunakan baja mutu tinggi dan sistem kerangka yang efisien. 


\section{BAB VIII GAYA INTERNAL}

\subsection{Gaya}

Gaya adalah penyebab yang mengubah sesuatu benda dari keadaan diam menjadi bergerak, atau sebaliknya. Contoh bila seseorang menarik sebuah benda dengan benang/tali, maka benda tersebut telah mendapatkan gaya sehingga benda itu berpindah

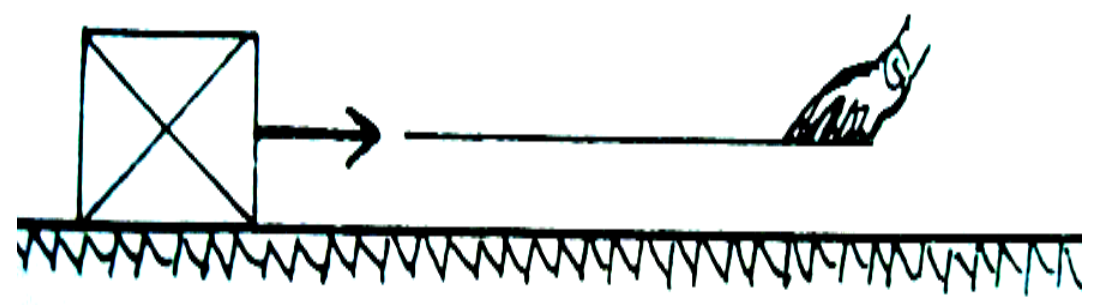

Gambar 8. 1 Pembangkitan Gaya

Gaya pada mekanika teknik dapat diartikan sebagai beban yang bekerja pada suatu konstruksi. Gaya merupakan besaran vektor atau aksi sebuah benda terhadap benda lain yang umumnya ditentukan oleh titik tangkap (kerja), besar dan arah. Sebuah gaya mempunyai besar, arah dan titik tangkap tertentu yang digambarkan dengan anak panah. Makin panjang anak panah makin besar gayanya.

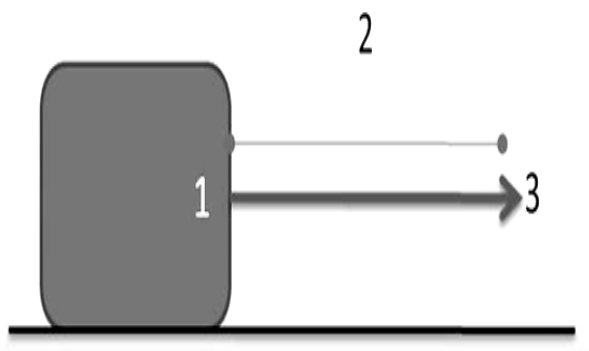

Keterangan:

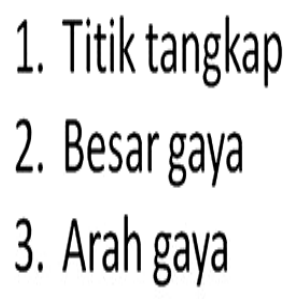

Gambar 8. 2 Unsur-unsur gaya (Sumber: Husin, 1989) 
gaya yang bekerja pada benda dapat dipindahkan sepanjang garis kerjanya.

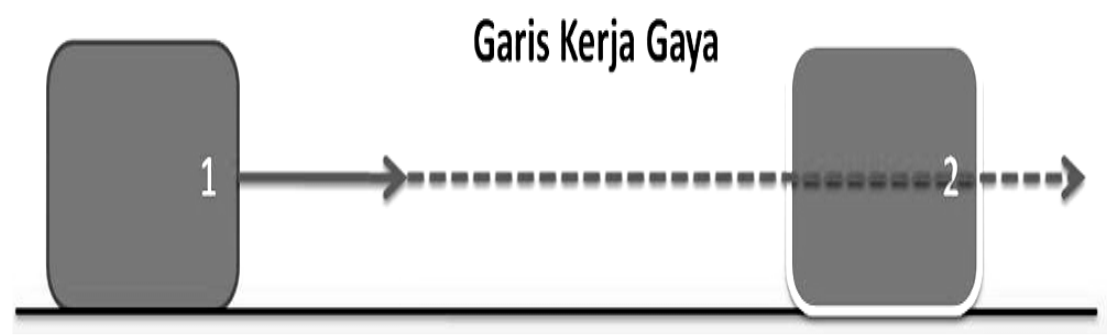

Gambar 8. 3 Garis kerja gaya

\section{Sistem Gaya}

Gaya dalam pengertian Mekanika Teknik adalah muatan pada suatu konstruksi yang dinyatakan dengan sepotong garis. Garis tersebut mempunyai:

\section{a. Besaran, Arah dan Titik Tangkap.}

Gaya dalam garis dijumlahkan secara aljabar Gaya dalam bidang dijumlahkan secara vektor

b. Jenis Gaya

\section{$\checkmark$ Gaya Kolinier :}

gaya-gaya yang garis kerjanya terletak pada satu garis lurus

\section{$\checkmark$ Gaya Konkuren}

gaya-gaya yang garis kerjanya berpotongan pada satu titik.

\section{Sifat Gaya}

$\checkmark$ Gaya dapat dipindahkan sepanjang garis kerjanya dan tidak berubah sifatnya.

$\checkmark$ Beberapa gaya dapat digantikan dengan satu (1) gaya pengganti yang disebut Resultan Gaya

$\checkmark$ Gaya boleh dipindahkan dari garis kerjanya apabila pada gaya tersebut ditambahkan suatu besaran kopel dan sifat gaya tidak berubah.

$\checkmark$ Kopel adalah 2 buah gaya sejajar sama besarnya dan berlawanan arah. Contoh gaya dipindahkan 


\section{Cara Pembebanan}

Berdasarkan cara pembebanan gaya terbagi menjadi tiga, yaitu: Gaya terpusat/beban terpusat Contoh : beban orang, beban kolom Modul Ajar Mekanika Teknik 23 $\checkmark$ Gaya terbagi

Contoh : beban plat beton, beban angin

$\checkmark$ Terbagi rata

$\checkmark$ Teratur

$\checkmark$ Tidak teratur

$\checkmark$ Gaya momen

Contoh : papan loncat indah, beban plat lantai

- Momen lentur

- Momen puntir

Gaya Internal adalah gaya yang ada di dalam badan struktur yang berusaha menjaga keseimbangan beban-beban luar yang bekerja pada struktur (Reaksi vertikal/Rv dan Reaksi horisontal/Rh). Aksi gaya eksternal (beban) menyebabkan timbulnya gaya internal (reaksi) di dalam elemen struktur. Timbulnya tegangan dan regangan internal. Tegangan adalah intensitas gaya/satuan luas $(\mathrm{N} / \mathrm{nm} 2)$.

\section{?? Reaksi (Rv)}

Jika pada balok dengan dua perletakan seperti pada gambar di bawah ini diberikan gaya $\mathrm{F}$ yang arahnya ke bawah, maka reaksi perletakan RA \& RB mengarah ke atas. 


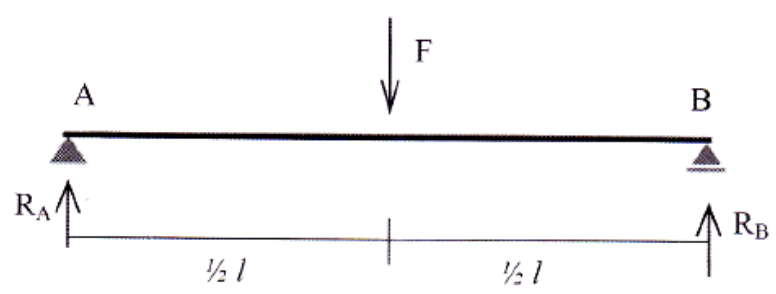

Gambar 8. 4 Arah reaksi pada balok 2 tumpuan Sumber: Sutarman, 2013

Gaya Internal dapat juga diartikan sebagai gaya pada badan struktur yang timbul akibat adanya keseimbangan gaya aksi dan reaksi. Gaya dalam tidak mungkin timbul jika gaya aksi dan reaksi tidak seimbang. Apabila pada suatu benda bekerja sebuah gaya, maka di dalam benda tersebut terjadi gaya lawan yang besarnya sama dengan gaya tersebut dalam satu garis kerja (gaya aksi = gaya reaksi, hukum Newton III). Tipe gaya internal, yaitu: Tarik, Tekan, Lentur, Geser, Torsi, Tumpu.

a. Gaya Tarik. Kecenderungan menarik elemen hingga putus. Kekuatan elemen tarik tergantung dari luas penampang, panjang dan materialnya. Tegangan Modul Ajar Mekanika Teknik 27 tarik/ gaya internal tarik terdistribusi merata pada penampang elemen (gaya/luas).

b. Gaya Tekan. Kecenderungan menyebabkan hancur atau tekuk pada elemen. Elemen pendek cenderung hancur, elemen panjang dapat tiba-tiba tertekuk/ fenomena buckling. Elemen panjang tidak dapat memikul beban yang besar.

c. Gaya Lentur. Umumnya terjadi di balok. Jika satu permukaan terjadi tekan, satu permukaan lain terjadi tarik. Tekan dan tarik terjadi pada satu penampang yang sama. Kekuatan terhadap lentur tergantung dari distribusi material pada penampang dan jenis material.

d. Gaya Geser. Aksi-aksi gaya berlawanan arah yang menyebabkan bagian struktur tergelincir/geser terhadap yang lain, umumnya terjadi pada balok 
e. Gaya Torsi. Torsi adalah fenomena puntir, dimana terjadi gaya rotasi berlawanan secara aksial pada penampang elemen struktur. Pada torsi, terjadi gaya tarik dan tekan.

\subsection{Jenis-Jenis Beban dan Tumpuan}

\section{Beban Terbagi Rata (q)}

- Bekerja sepanjang muatan

- Dinyatakan dalam q (t/m') atau sebesar q ton untuk tiap meter

- Titik berat bidang empat persegipanjang terletak pada setengah panjang persegipanjang

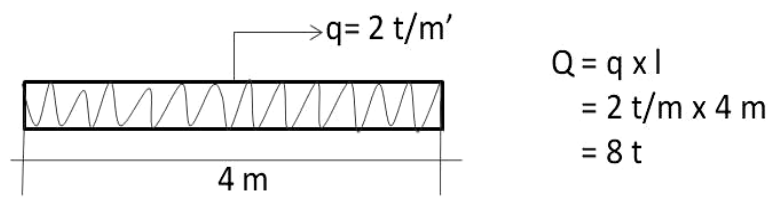

Gambar 8. 5 Beban terdistribusi

\section{Beban terpusat/ Beban Segitiga}

Adalah muatan/beban yang luas singgungnya merata tapi muatannya tidak terbagi rata. Misanya: tekanan air pada dinding bak air, kolam atau tekanan air pada pintu air. Dinding-dinding tegak mendukung desakan air yang besarnya sebanding dengan jarak dari permukaan air (semakin dalam semakin besar desakannya).

Pada umumnya beban tak hanya terpusat atau terbagi rata, namun ada yang berbentuk segitiga seperti beban tekanan air dan tanah. Prinsip dasar penyelesaiannya adalah sama dengan yang lain, namun kita harus lebih hati-hati karena bebannya membentuk persamaan. 


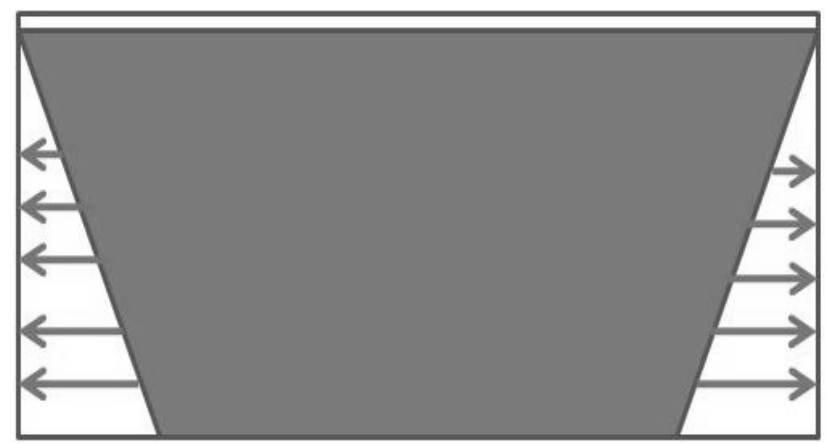

Gambar 8. 6 Beban terpusat/segitiga

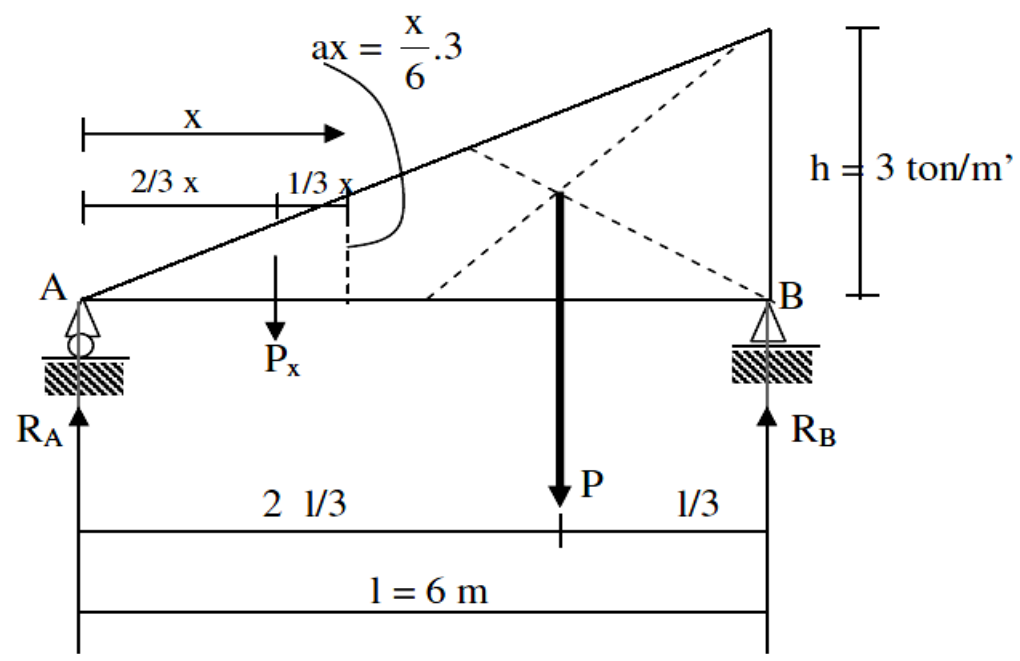

Gambar 8. 7 Titik berat massa beban segitiga

Sumber: Sutarman, 2013

\section{Beban menurut cara kerjanya pada konstruksi}

a. Muatan langsung yaitu beban bekerja langsung di atas balok, tanpa perantara bagian lain. Beban yang langsung ditopang (plat terhadap balok).

b. Muatan tidak langsung yaitu beban yang melalui perantara lain diteruskan (balok beton terhadap pondasi). Beban bekerja secara tidak langsung di atas balok utama. Misalnya pada bentangan yang besar, bentang dibagi dalam 4 bagian menjadi beban terpusat. Beban diteruskan pada balok 
utama dengan perantaraan balok memanjang \& pemikul melintang.

\section{Landasan/Tumpuan}

Tumpuan adalah tempat bersandarnya konstruksi dan tempat bekerjanya reaksi. Jenis tumpuan berpengaruh terhadap jenis konstruksi, sebab setiap jenis tumpuan mempunyai karakteristik sendiri. Jenis tumpuan tersebut adalah:

1. Tumpuan Sendi / Engsel

2. Tumpuan Rol

3. Tumpuan Jepit

4. Tumpuan Gesek

5. Tumpuan Bidang Rata

6. Tumpuan Tali Pendel

7. Tumpuan Titik

Dari jenis - jenis tumpuan tersebut yang banyak dijumpai dalam bangunan adalah tumpuan Sendi, Rol, dan Jepit. Dengan demikian hanya tumpuan Sendi, Rol, dan Jepit yang akan diuraikan karakteristiknya.

\section{Sendi/Engsel}

? Untuk menahan gaya tekan, tarik dengan arah sembarang, melalui pusat sendi.

? Tidak dapat menahan momen atau meneruskan momen.

? Diproyeksikan atas reaksi vertikal \& horisontal.
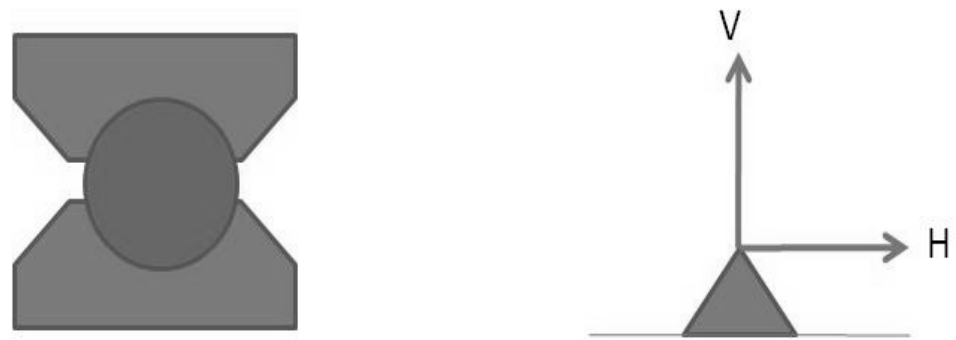

Gambar 8. 8 Sendi engsel 


\section{Rol}

* Tidak dapat menahan gaya tarik dan tekan sembarang arah,dan hanya arah vertikal.

* Di proyeksikan atas reaksi vertikal.
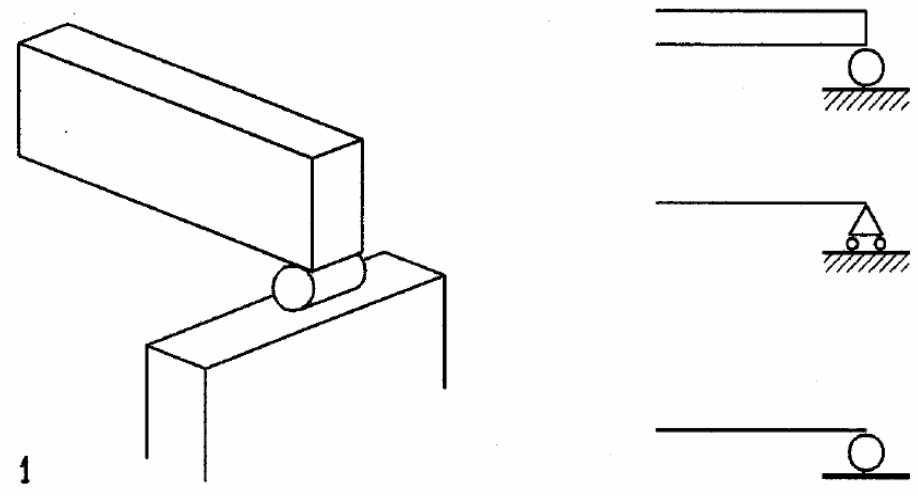

Gambar 8. 9 Jenis tumpuan rol

Sumber: Schierle, 2006

\section{Jepit}

* ?]Dapat menahan gaya tekan \& tarik sembarang arah

* Dapat meneruskan momen.

* Diproyeksikan atas reaksi vertikal, horisontal dan momen.
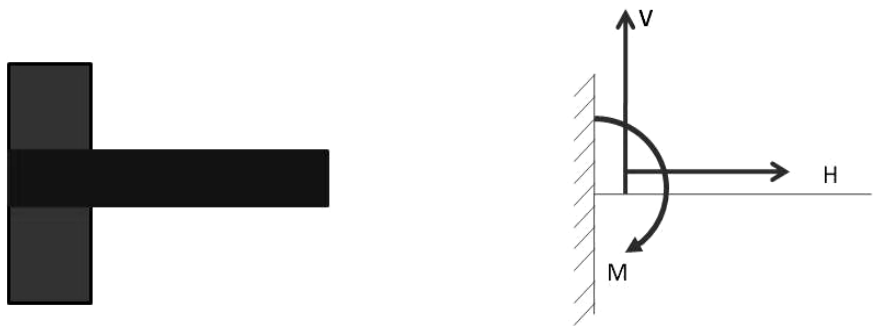

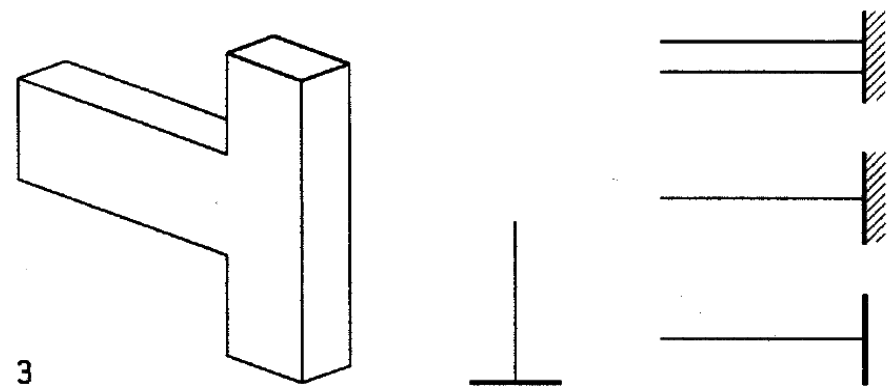

Gambar 8. 10 Jenis tumpuan Jepit

Sumber: Schierle, 2006

\subsection{Gaya Geser dan Momen Bending Pada Beam}

\section{Balok dan Gaya}

Balok (beam) adalah suatu batang struktural yang didesain untuk menahan gaya-gaya yang bekerja secara transversal terhadap sumbunya. Apabila beban yang dialami pada balok bukan merupakan beban transversal, beban itu akan menghasilkan torsi pada balok. Namun, torsi biasanya sering diabaikan dalam merancang balok karena suatu balok lebih mampu mempertahankan pergeseran dan pelenturan dibandingkan menahan torsi.(Beer, 1996) Balok biasanya berbentuk panjang, lurus seperti prismatik. Perancangan suatu balok terdiri atas pemilihan bagian komponen yang akan menahan pergeseran dan pelenturan yang dihasilkan oleh suatu pembebanan. Perancangan suatu balok meliputi dua bagian yang berbeda, bagian yang pertama merupakan perhitungan gaya geser (shear) dan momen lentur (bending) yang dihasilkan oleh beban. Bagian kedua berhubungan dengan pemilihan bagian komponen terbaik untuk menahan gaya geser dan momen lentur yang telah dihitung pada bagian pertama.

Gaya (force) didefinisikan sebagai tarikan atau dorongan yang bekerja pada sebuah benda yang dapat mengakibatkan perubahan gerak. Biasanya, gaya mengakibatkan dua pengaruh, pertama menyebabkan sebuah benda bergerak, dan kedua 
menyebabkan terjadinya deformasi pada benda. Pengaruh pertama disebut juga pengaruh luar (external effect) dan yang kedua disebut pengaruh dalam (internal effect).

Apabila beberapa gaya bekerja pada sebuah benda, gayagaya tersebut dinyatakan sebagai sistem gaya (force system). Jika sistem gaya yang bekerja pada sebuah benda tidak mengakibatkan pengaruh luar, gaya dinyatakan setimbang (balance) dan benda dikatakan berada dalam kesetimbangan (equilibrium).

\section{Gaya Geser dan Momen Lentur (Shear Force and Bending Moment)}

Jika sebuah balok dikenai beban transversal seperti pada Gambar 2.3, maka akan terjadi gaya geser dan momen lentur pada balok tersebut.

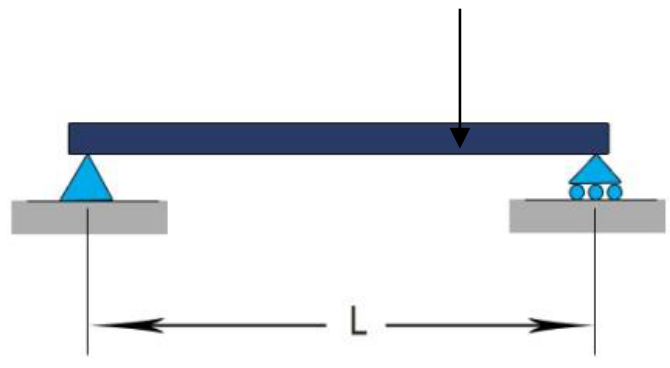

Gambar 8. 11 Beban Transversal pada Balok

Dalam menentukan gaya geser dan momen lentur perlu diperhatikan kondisi kesetimbangan. Semua gaya eksternal yang terjadi, baik gaya luar maupun reaksi harus berada dalam kondisi kesetimbangan. Untuk mempermudah perhitungan gaya dan momen pada balok, maka perlu dibuat diagram benda bebas (Free Body Diagram) seperti pada Gambar 2.4. 


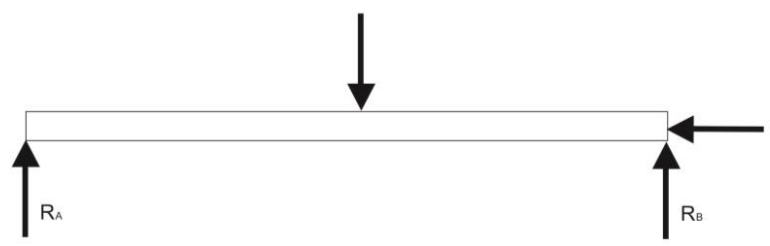

Gambar 8. 12 Diagram Benda Bebas

Gaya geser merupakan jumlah dari komponen tegak lurus terhadap balok dari beban luar yang bekerja pada penampang sebuah benda. Definisi gaya geser ini bisa dinyatakan secara matematis yaitu:

$$
\mathrm{V}=(\Sigma \mathrm{Fy})
$$

zahanan geser $V^{\prime}$ yang ditimbulkan oleh segmen balok selalu sama, tetapi arahnya berlawanan dengan gaya geser $\mathrm{V}$. Ketika menghitung $\mathrm{V}$, gaya atau beban yang bekerja ke atas dianggap positif. Hukum tanda ini menghasilkan pengaruh seperti terlihat pada Gambar 2.5.

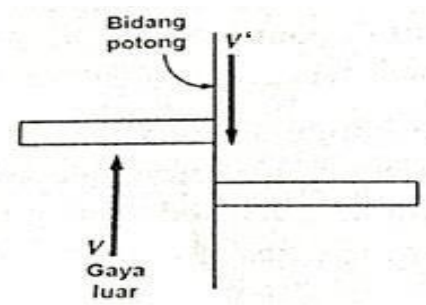

(a) Gaya geser positif (+)

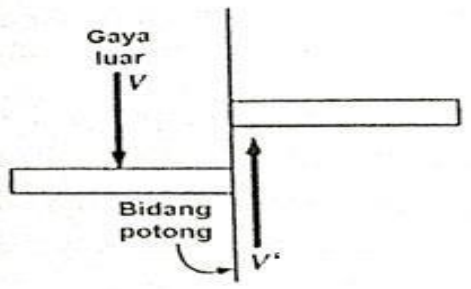

(b) Gaya geser negatif (-)

Gambar 8. 13 Tanda Gaya Geser (Zainuri,2008)

Dengan R1 dan disebut momen bending dan segmen penampang menimbulkan momen tahanan $\mathrm{M}^{\prime}$ (lihat Gambar 2.6). 


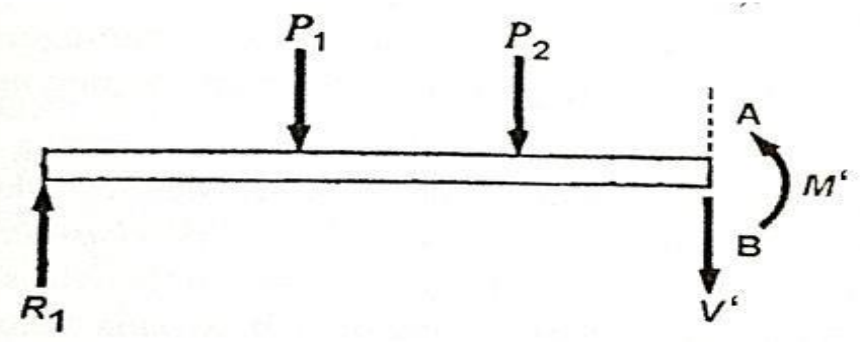

Gambar 8. 14 Definisi Momen Lentur (Zainuri,2008)

Momen lentur didefinisikan sebagai jumlah momen semua gaya yang bekerja terhadap penampang balok dan dinyatakan secara matematis sebagai:

$$
\mathrm{M}=(\Sigma \mathrm{My})
$$

Dengan mengacu Gambar 2.5, konvensi tanda momen lentur adalah momen lentur positif apabila momen menghasilkan lenturan balok cekung ke atas. Begitu pula sebaliknya, seperti Gambar 2.7. Kita memilih pemakaian konvensi ekuivalen yang menyatakan bahwa gaya luar yang bekerja ke atas menghasilkan momen lentur negatif. (Zainuri, 2008)

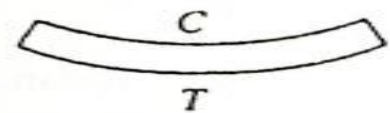

(a) Momen bending positive

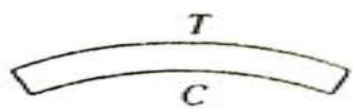

(b) Momen bending negative

Gambar 8. 15 Tanda Momen Lentur (Zainuri,2008)

Berikut ini adalah contoh untuk menentukan gaya geser dan momen lentur pada suatu balok. Perhatikan balok yang disangga seperti pada Gambar 2.8(a). Karena balok dalam 
keadaan setimbang, setiap bagian balok juga pasti akan setimbang. Karena itu, untuk menganalisis pengaruh internal pada tiap penampang atau potongan balok, misalnya saja pada penampang z-z, bayangkan apabila balok dipotong pada tempat tersebut, seperti terlihat pada Gambar 2.8(b) atau (c). Jelas bahwa kedua bagian balok yang terpotong akan jatuh, kecuali bila diberi gaya $\mathrm{V}$ dan momen $\mathrm{M}$ (seperti terlihat pada gambar) untuk mempertahankan keadaan setimbang tersebut. Karena itu gaya dan momen tersebut harus dibuat secara internal dalam balok yang tak terpotong. Karena gaya $V$ sejajar dengan permukaan bagian yang terpotong, maka gaya tersebut merupakan gaya geser. Momen $M$ akan menyebabkan potongan z-z berputar, sehingga balok melentur, karena itu disebut momen lentur.

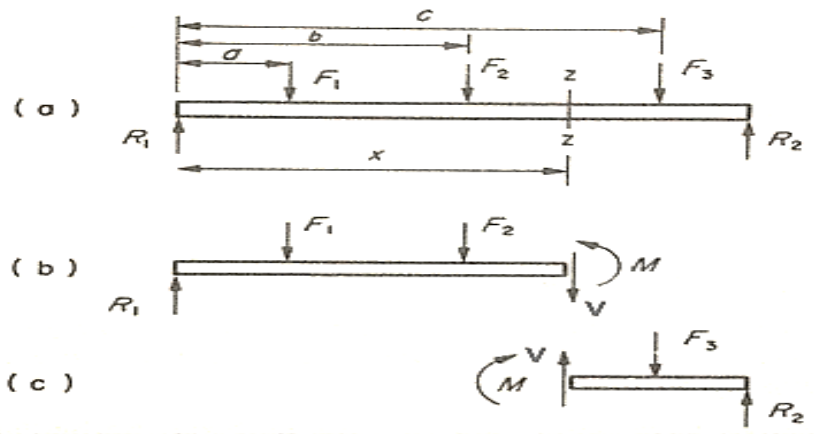

Gambar 8. 16 Gaya dan Momen pada Balok . (Titherington, 1984)

Untuk menentukan besarnya $\mathrm{V}$ dan $\mathrm{M}$, cukup dipakai syaratsyarat kesetimbangan pada salah satu bagian balok yang terpotong. Jadi, dari Gambar 2.8(b), karena jumlah semua gaya vertikal harus sama dengan nol, maka:

$\mathrm{R} 1-\mathrm{F} 1-\mathrm{F} 2-\mathrm{V}=0$

Jadi

$\mathrm{V}=\mathrm{R} 1-\mathrm{F} 1-\mathrm{F} 2$ 
Atau

$\mathrm{V}=\mathrm{R} 1+(-\mathrm{F} 1)+(-\mathrm{F} 2)$

Dari persamaan ini dapat disimpulkan:

Gaya geser pada penampang balok sama dengan jumlah semua gaya transversal pada balok yang bekerja di bagian kiri atau kanan penampang tersebut. Pernyataan ini adalah definisi gaya geser pada penampang suatu balok. Perlu dicatat bahwa bila gaya di bagian kiri penampang dijumlahkan, maka gaya ke atas dianggap positif dan gaya ke bawah dianggap negatif.

Sekali lagi, dari Gambar 2.8(b), momen-momen terhadap zz menghasilkan:

$R x=M+F 1(x-a)+F 2(x-b)(2.6)$

Sehingga

$\mathrm{M}=\mathrm{Rx}-\mathrm{F} 1(\mathrm{x}-\mathrm{a})-\mathrm{F} 2(\mathrm{x}-\mathrm{b})(2.7)$

Persamaan ini menghasilkan definisi momen lenturan:

Momen lenturan pada penampang suatu balok adalah jumlah momen semua gaya yang bekerja pada salah satu sisi penampang terhadap penampang tersebut. (Titherington, 1984). Gaya internal yang terjadi pada suatu balok akan menghasilkan tegangan pada balok tersebut. Tegangan yang terjadi pada balok diantaranya adalah tegangan geser dan tegangan lenturan. (Anonim, 2014)

Tegangan Geser pada balok dihasilkan oleh gaya geser. Karena adanya usaha untuk memutar penampang melawan tahanan elastik bahan, maka momen lentur menghasilkan tegangan normal pada penampang transversal balok, dan bervariasi dari tarik hingga tekan. Tegangan ini disebut tegangan lentur. Tegangan lentur hampir selalu jauh lebih besar dari tegangan geser, sehingga perhitungan momen lenturan, khususnya, momen lentur maksimum dalam balok merupakan sasaran utama. (Titherington, 1984)

Tegangan Geser berbeda dengan tegangan Tarik dan tekan karena tegangan geser disebabkan oleh gaya yang bekerja sepanjang atau sejajar dengan luas penahan gaya, sedangkan tegangan tarik dan tekan disebabkan oleh gaya yang tegak lurus 
terhadap luas bidang gaya. Oleh karena itu, tegangan tarik dan tekan biasanya disebut tegangan normal, sedangkan tegangan geser disebut tegangan tangensial. Tegangan geser terjadi apabila beban terpasang menyebabkan salah satu penampang benda cenderung menggelincir pada penampang yang bersinggungan. Beberapa contoh diperlihatkan pada Gambar 2.9. Pada beberapa kasus, geser terjadi di sepanjang luas yang sejajar dengan beban kerja. Kasus ini disebut geser langsung searah yang berlawanan dengan geser induksi yang bisa terjadi pada penampang miring dengan beban resultan.
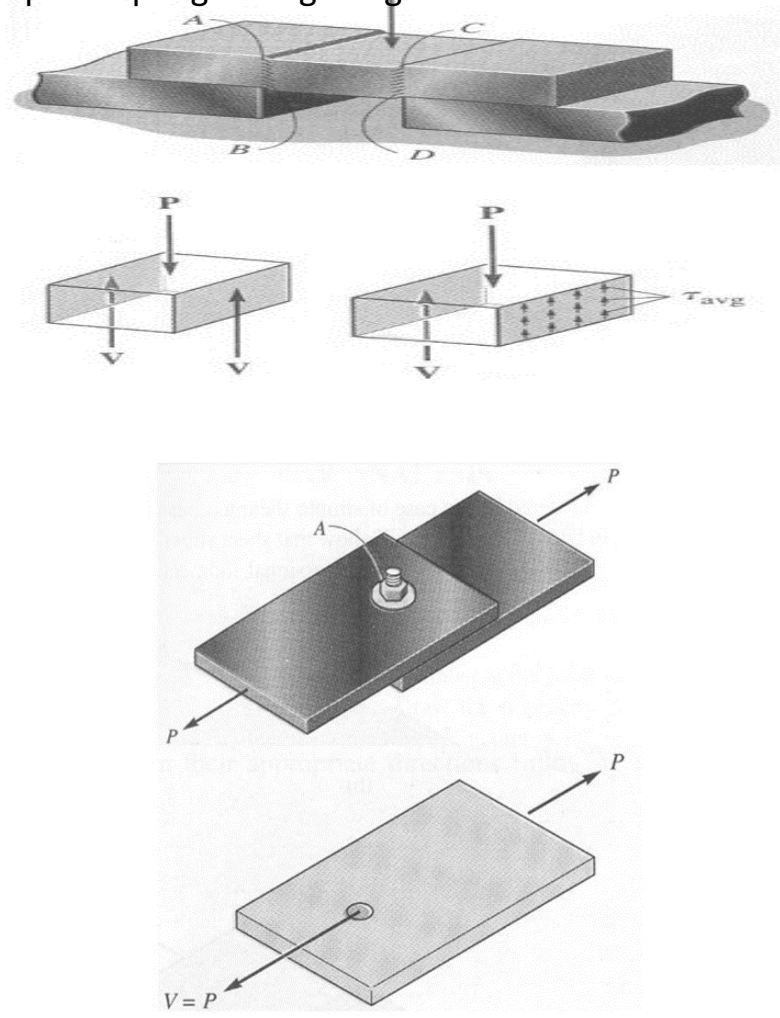

Gambar 8. 17 Distribusi Tegangan Geser (Hibbeler, 2004) 
Tegangan geser merata akan terjadi bila resultante gaya geser $\mathrm{V}$ melalui titik pusat penampang yang bergeser. Apabila hal ini benar, tegangan geser $\tau$ (huruf yunani tau) dapat diperoleh dari:

$$
\tau=\frac{V}{A}
$$

Sebenarnya, pada praktiknya tegangan geser tidak pernah terbagi secara merata, sehingga persamaan 2.8 harus diterjemahkan sebagai tegangan geser rata-rata. Hal ini tidak membatasi kegunaan persamaan 2.8 yang telah diberikan, maka dipergunakan tegangan geser rata-rata ke dalam perhitungan distribusi tidak merata aktual. Selanjutnya distribusi tegangan geser mendekati kemerataan apabila jarak antara beban geser yang bekerja dan kedalaman luas geser keduanya kecil. (Singer, 1995)

Apabila suatu balok mengalami beban momen maka akan terjadi lenturan pada balok tersebut sehingga balok akan mengalami defleksi seperti yang terlihat pada Gambar 2.10.

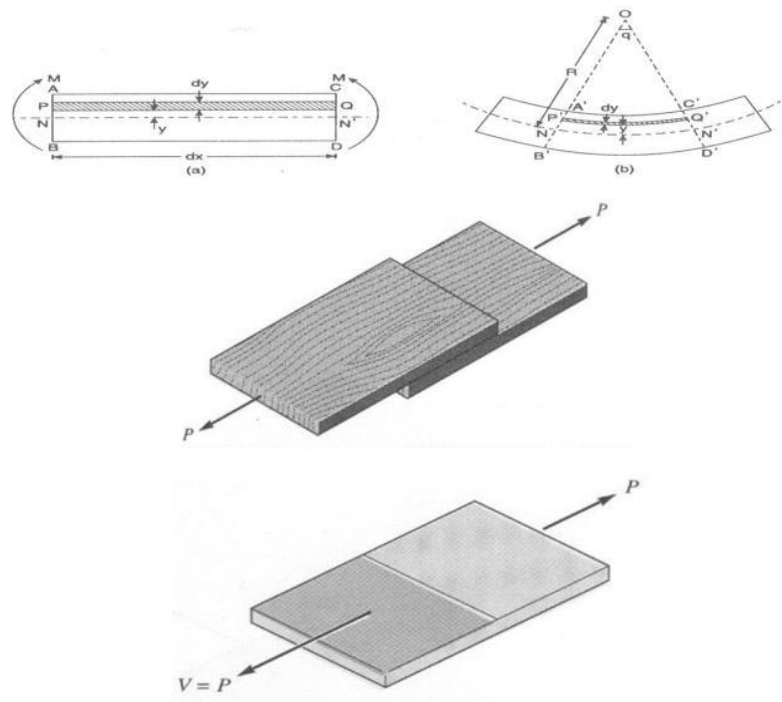


Gambar 8. 18 Lenturan pada Balok (www.transtutors.com)

Balok yang mengalami lenturan tersebut memiliki ditribusi tegangan seperti pada Gambar 2.11 akibat lenturan, yang dapat dinyatakan secara matematis sebagai:

$$
\sigma=\frac{M \cdot y}{I x}
$$

Dimana $\sigma$ merupakan tegangan normal akibat lentur, $M$ merupakan momen luar, y merupakan jarak tegangan yang ditinjau ke garis netral, dan Ix merupakan momen inersia terhadap sumbu x. (Beer, 2009).
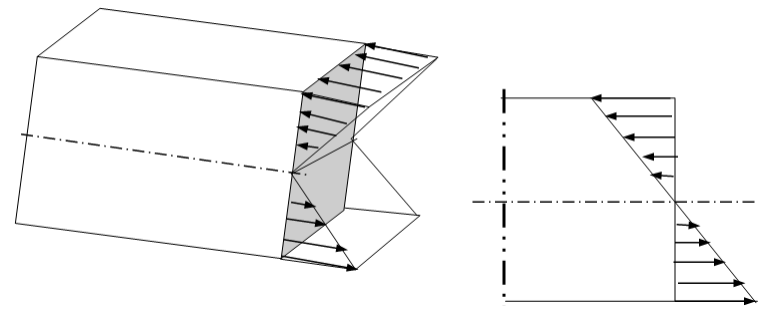

Gambar 8. 19 Distribusi Tegangan Akibat Lentur (suryasebayang.files.wordpress.com, 2011)

\subsection{Diagram Gaya Geser dan Momen Lentur}

Dalam mendesain dan menganalisis balok sangatlah penting untuk menghitung nilai-nilai maksimum dari gaya geser dan momen lentur. Oleh karena itu, sangatlah penting untuk menentukan variasi gaya geser dan momen lentur sepanjang $\mathrm{L}$ balok. Hal ini dilakukan dengan menggunakan sistem grafis yang disebut diagram gaya geser dan diagram momen lentur.

Diagram gaya geser biasanya digambar secara langsung berdasarkan sketsa diagram benda bebas. Garis utama (baseline) gaya geser menunjukan gaya geser nol digambar sejajar balok. Absis $x$ sepanjang garis utama menunjukan lokasi 
potongan beban pada balok. Ordinat y menunjukan nilai gaya geser pada diagram gaya geser. Diagram momen lentur umumnya digambar di bawah diagram gaya geser. Garis utama momen menunjukan momen lentur nol, digambar sejajar garis utama gaya geser. Sebagaimana gaya geser, absis $x$ dan ordinat y menunjukan lokasi potongan momen pada balok dan nilai momen pada diagram.

Berikut adalah hal-hal penting berkenaan diagram momen lentur:

1. Momen lentur pada ujung-ujung tumpuan sederhana akan selalu berharga nol, dengan catatan bahwa balok tidak diberi beban momen.

2. Apabila beban diberikan secara vertikal ke bawah, momen lentur pada ujung bebas balok kantilever selalu berharga nol dan momen lentur maksimum terjadi pada ujung tetap. Gaya geser juga berharga maksimum pada ujung tetap.

3. Momen lentur selalu positif pada balok tumpuan sederhana dan negatif pada balok kantilever, dengan asumsi semua beban vertikal ke bawah.

4. Kecuali balok kantilever, momen lentur maksimum selalu terjadi pada titik dengan gaya geser nol atau diagram gaya geser melalui nilai nol.

Sebagai suatu contoh, perhatikan balok $A B$ dengan panjang $L$ yang ditumpu sederhana dan diberi beban terpusat $P$ dan terletak pada titik D seperti pada Gambar 2.12. Pertama ditentukan gaya reaksi pada tumpuan dari diagram benda bebas pada balok seperti pada Gambar 2.12(b). Didapat bahwa besarnya reaksi adalah $\mathrm{P} / 2$.

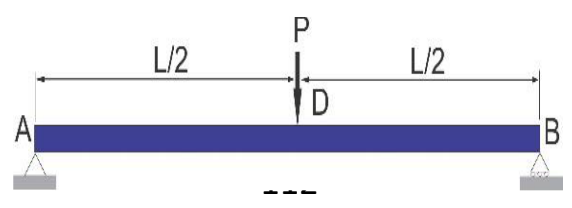



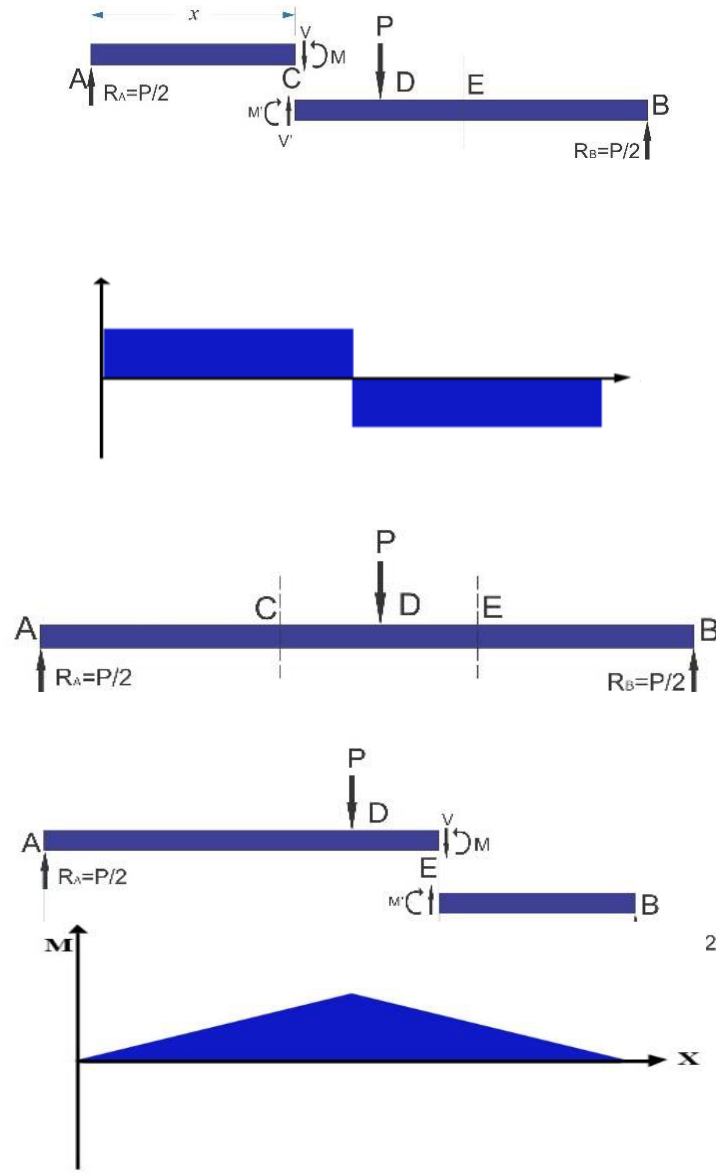

Gambar 8. 20 Pembuatan Diagram Gaya Geser dan Momen Lentur (Beer,1996)

Kemudian balok dipotong pada titik $\mathrm{C}$ di antara $\mathrm{A}$ dan $\mathrm{D}$ lalu gambar diagram benda bebas AC dan CB seperti pada Gambar 2.12(c). Pada benda bebas AC, jumlah total gaya vertikal dan jumlah dari momen yang bereaksi pada titik $\mathrm{C}$ adalah nol, maka 
didapatkan $\mathrm{V}=\mathrm{P} / 2$ dan $\mathrm{M}=\mathrm{Px} / 2$. Kedua gaya geser dan momen lentur bernilai positif. Setelah itu nilai-nilai tersebut dapat digambarkan pada diagram $\mathrm{V}$ dan $\mathrm{M}$ di antara $\mathrm{A}$ dan $\mathrm{D}$ seperti pada Gambar 2.12(e) dan (f). Gaya geser memiliki nilai konstan $\mathrm{V}=\mathrm{P} / 2$, sedangkan momen lentur meningkat linear dari $\mathrm{M}=0$ pada $\mathrm{x}=0$ sampai $\mathrm{M}=\mathrm{PL} / 4$ pada $\mathrm{x}=\mathrm{L} / 2$.

Lalu potong balok pada titik $E$ antara D dan B. Pada benda bebas EB, jumlah gaya vertikal dan jumlah momen yang bereaksi pada titik $E$ adalah nol. Maka didapatkan $V=-P / 2$ dan $M=P /(L-x) / 2$. Nilai gaya geser negatif. Sedangkan momen lentur bernilai positif. Setelah itu, diagram gaya geser dan momen lentur pada gambar 2.12(e) dan (f) dapat dilengkapi. Gaya geser memiliki nilai konstan $\mathrm{V}=-\mathrm{P} / 2$ di antara titik $\mathrm{D}$ dan $\mathrm{B}$, sementara $M$ turun secara linear dari $M=P L / 4$ pada $x=L / 2$ hingga $M=0$ pada $\mathrm{x}=\mathrm{L}$. (Beer, 1996)

Contoh lain yang sederhana adalah balok kantilever yang mengalami gaya tunggal yang terpusat pada ujung bebasnya (gambar 2.13(a)). Perhatikan penampang pada jarak $\mathrm{x}$ dari ujung bebas,

\section{Gaya geser $\mathbf{V}=-\mathbf{W}$ \\ Momen lentur $\mathbf{M}=-\mathbf{W x}$}

Persamaan gaya geser menunjukan bahwa $v$ sama untuk semua harga $x$, sedangkan persamaan momen lentur menunjukan bahwa besarnya $\mathrm{M}$ bertambah secara tetap, dari nol pada ujung bebas hingga WL pada ujung tetap.
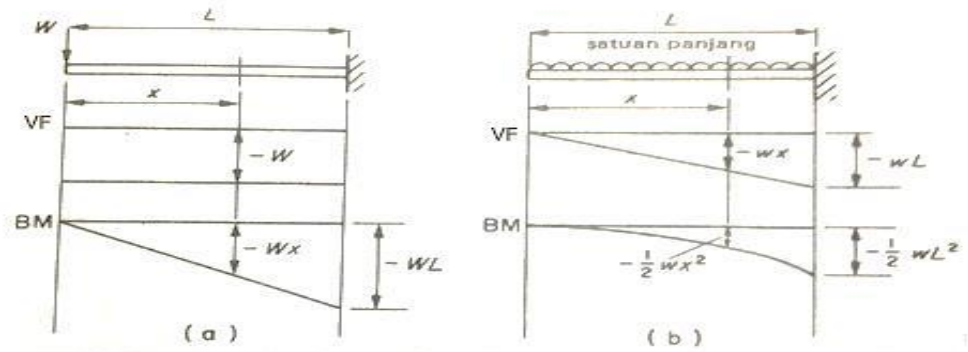
Gambar 8. 21 Diagram Gaya Geser dan Momen Lentur Kantilever (Titherington,1984)

Bila beban terdistribusi diberikan secara merata pada kantilever, seperti ditunjukkan dalam Gambar 2.13(b), maka persamaan gaya geser dan momen lentur adalah:

$$
\begin{aligned}
& \mathrm{V}=-\mathrm{w} x(2.10) \\
& \mathrm{M}=-\mathrm{w} x(x / 2)=-12 w x 2
\end{aligned}
$$

Beban total ke bawah di sebelah kiri penampang yang diamati adalah wx, dan karena distribusinya merata, maka pusat gravitasi akan jatuh di tengah-tengah panjang $x$, sehingga lengan momen adalah $\mathrm{x} / 2$.

Karena itu diagram gaya geser adalah linear dan diagram momen lentur adalah parabolik, seperti terlihat dalam Gambar 2.13(b).

Dua contoh sederhana yang lain adalah balok yang ditumpu sederhana dan dipengaruhi (a) beban tunggal $W$ yang terpusat di titik tengah dan (b) beban w yang didistribusikan merata pada seluruh panjangnya. Contoh-contoh ini ditunjukan dalam Gambar 2.14(a) dan (b).

Dalam gambar $2.13(b)$, persamaan gaya geser dan momen lentur dijabarkan sebagai berikut. Perhatikan penampang pada jarak $\mathrm{x}$ dari penumpu kiri,

$$
\begin{aligned}
= & 12 w L-w x(2.12) \\
M & =12 w(x)-w x(x / 2) \\
& =12 w L x-12 w x 2(2.13)
\end{aligned}
$$

$\mathrm{M}$ akan maksimum bila $\mathrm{dM} / \mathrm{dx}=0$. Bila persamaan momen lentur di diferensiir,

$$
\frac{d . M}{d \cdot x}=\frac{1}{2} \quad w L x-\quad \frac{1}{2} \quad \mathrm{wx}^{2}
$$

$\mathrm{M}$ akan maksimum bila $\mathrm{dM} / \mathrm{dx}=0$. Bila persamaan momen lentur di diferensiir,

$$
\frac{d . M}{d \cdot x}=\frac{1}{2} \quad w L-\mathrm{wx}
$$



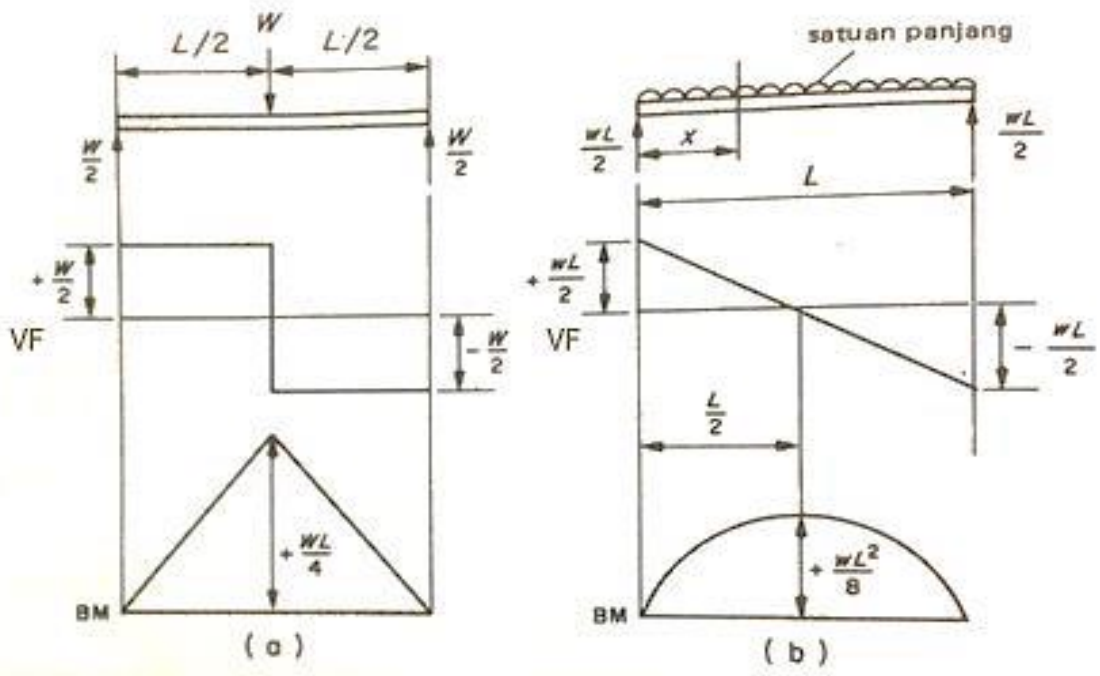

Gambar 8. 22 Diagram Gaya Geser dan Momen Lentur Simple Beam (Titherington,1984)

Jadi, $M$ adalah maksimum bila $1 / 2 w L-w x=0$, atau bila $x=$ $\mathrm{L} / 2$. Karena itu momen lentur maksimum terjadi di titik tengah balok, dan dinyatakan oleh:

$$
\operatorname{Mmax}=\frac{1}{2} \mathrm{WL}\left(\frac{L}{2}\right)-\frac{1}{2} \mathrm{~W}\left(\frac{L}{2}\right)^{2}=\frac{\mathrm{WL}^{2}}{8}
$$

Akan terlihat bahwa pernyataan untuk $\mathrm{dM} / \mathrm{dx}$ adalah sama dengan $V$. hal ini bukan suatu kebetulan karena dapat dibuktikan bahwa gaya geser dan momen lenturan dihubungkan oleh persamaan: 


$$
\mathrm{V}=\frac{d M}{d x}
$$

Dengan kata lain, gaya geser selalu sama dengan laju perubahan momen lenturan sepanjang balok, dan momen lenturan adalah maksimum bila gaya geser sama dengan nol.

Karena biasanya gaya geser dan momen lentur berbedabeda sepanjang struktur balok, maka perubahan gaya geser dan momen lentur digambarkan dengan grafik untuk mempermudah melihat perubahan tersebut. Grafik ini disebut diagram gaya geser dan diagram momen lentur. (Titherington,1984)

\subsection{Beban Kabel dengan Beban Terpusat}

Kabel banyak digunakan dalam aplikasi teknik, seperti halnya jembatan gantung, kawat tali untuk menara tinggi dan sebagainya. Secara umum kabel dapat dibagi dua, yakni kabel dengan bebanterkonsentrasi dan kabel dengan beban terdistribusi. Pada bagian iniakan dibahas bagian pertama.

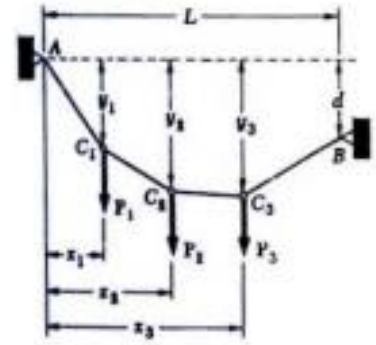

(a)

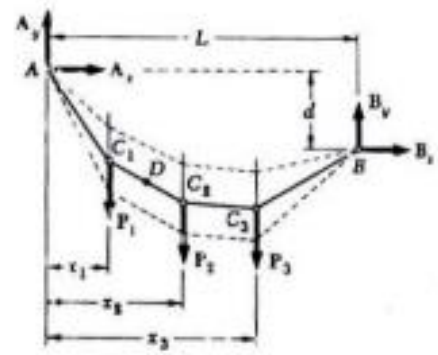

(b)

Gambar 8. 23 Kabel Dengan Beban Terkonsentrasi

Pada gambar 10 terlihat kabel yang dikaitkan pada suatu titik $A$ dan B tertentu dan menunjang beban terkonsentrasi P1,P2 dan P3. Diandaikan kabel tersebut lentur, yaitu tahanan terhadap 
pelengkungan kecil dan dapat diabaikan. Juga berat kabel dapat diabaikan.

Definisi kabel dengan beban terpusat sebagai konstruksi statis tertentu, Analisa gaya dan tegangan pada kabel dengan beban terpusat, Definisi kabel parabola sebagai konstruksi statis tertentu, Analisa gaya dan tegangan pada kabel parabola.

beban yang ditunjangnya. Karena itu tiap sub-bagian kabel antara kabel yang berturutan boleh dianggap sebagai bagian dua-gaya, dan gaya internal pada tiap titik dalam kabel tereduksi menjadi gaya tegangan yang berarah sepanjang kabel.

Diandaikan bahwa tiap beban terletak pada garis vertical yang diberikan, berarti bahwa jarak horizontal dan vertikal antara dua titik tunjang diketahui. Diusulkan untuk menentukan bentuk dari kabel, artinya, jarak vertical dari A pada titik-titik C1,C2,C3 dan juga tegangan $T$ dalam tiap sub bagian dai kabel dianggap tertentu.

Pertama, digambar diagram benda bebas dari keseluruhan kabel. Karena kemiringan dari sub-bagian kabel yang dikaitkan pada $A$ dan $B$ tidak diketahui, reaksi pada $A$ dan $B$ harus diwakili masing-masing oleh dua komponen Ax dan Ay serta Bx dan By. Demikianlah, karena terdapat empat nilai yang tak diketahui maka tiga persamaan kesetimbangan yang ada tidaklah mencukupi untuk menentukan reaksi-reaksi itu. (Jelas, kabel bukan benda tegar; karena itu persamaan kesetimbangan yang dikemukakan perlu tetapi bukan kondisi yang cukup). Karenanya harus dicari persamaan tambahan dengan meninjau kesetimbangan dari subbagian kabel. Ini mungkin apabila diketahui koordinat $\mathrm{x}$ dan $\mathrm{y}$ dari sembarang titik $\mathrm{D}$ pada kabel. Dengan menggambar diagram benda bebas dari sub-bagian pada kabel $A D$ dan menulis $2 \mathrm{MD}=0$, didapatkan hubungan tambahan antara komponen scalar Ax dan Ay dan dapat ditentukan reaksi pada A dan B. Namun persoalan akan menjadi statiktak tentu apabila tidak diketahui koordinat titik D, kecuali hubungan antara Ax dan Ay (atau antara Bx dan By) diberikan. Kabel dapat tergantung dalam berbagai variasi yang mungkin, sebagaimana ditunjukkan oleh garis putus-putus dalam gambar 8.23. 


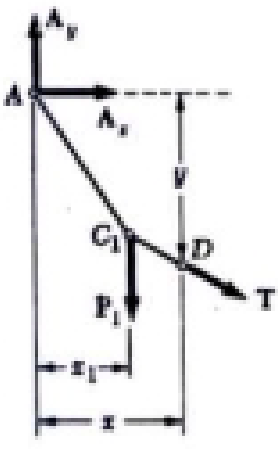

(a)

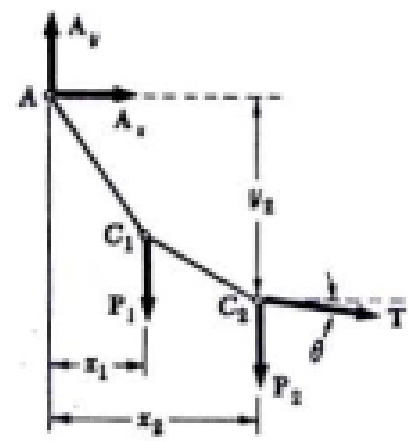

(b)

Gambar 8. 24 Diagram Benda Bebas Sub-Bagian Kabel Sekali Ax dan Ay dapat ditentukan, jarak vertical dari A pada tiap titik manapun dari kabel dapat dengan mudah ditemukan. Dengan memperhatikan titik C2 misalnya, dapat digambar diagram benda bebas dari sub-bagian kabel AC2. Dengan menuliskan MC2 $=0$ didapat satu persamaan yang dapat diselesaikan untuk y2. Dengan menulis [ $\mathrm{Fx}=0$, dan [Fy $=0$ diperoleh komponen dari gaya $\mathrm{T}$ yang mewakili tegangan dalam sub bagian kabel disebelah kanan dari C2. Dapat diamati bahwa $\mathrm{T} \cos$ ? ?]= -Ax; komponen horizontal dari gaya tegangan adalah sama pada titik manapun dari kabel. Kesimpulannya ialah tegangan T maksimum bila cos? ?minimum, berarti dalam sub bagian kabel yang mempunyal sudut inklinasi ?] ?terbesar. Jelaslah, sub-bagian kabel ini harus berdekatan dengan satu dari dua penunjang kabel.

\section{A. Kabel Dengan Beban Terdistribusi.}




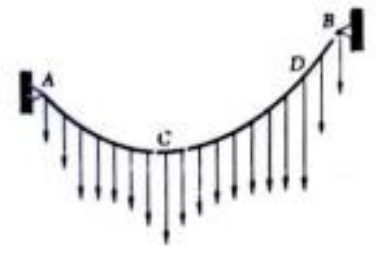

(s)

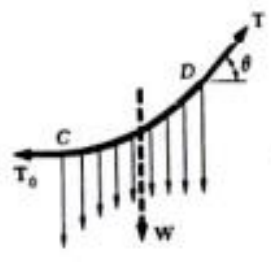

(b)

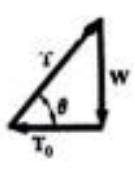

(c)

Gambar 8. 25 Gaya terdistribusi pada kabel

Pada gambar 12 diperlihatkan seutas kabel dikaitkan pada dua titik tertentu A dan B dan membawa beban terdistribusi. Pada bagian kabel dengan beban terkonsentrai, gaya internal pada tiap titik adalah suatu gaya tegangan yang berarah sepanjang kabel. Dalam kasus kabel membawa suatu beban terdistribusi, kabel menggantung dalam bentuk

kurva, dan gaya internal pada titik $D$ adalah gaya tegangan $T$ yang berarah sepanjang garis singgung dari kurva. Jika diberikan beban terdistribusi tertentu, dapat diusulkan dalam bagianini untuk menentukan tegangan pada tiap titik dari kabel. Dapat juga dilihat nantinya,

bagaimana bentuk kabel dapat ditentukan untuk dua jenis beban terdistribusi yang istimewa (parabola dan katenary). Dengan memperhatikan kasus sangat umum dari beban

terdistribusi, digambar diagram benda bebas dari sub-bagian kabel. memanjang dari titik terendah $C$ ke titik yang diberikan $D$ dari kabel itu. Gaya yang bereaksi pada benda bebas adalah gaya tegangan To pada $C$ yang horizontal, dan tegangan $T$ pada $D$, berarah sepanjang garis singgung pada kabel di $D$, dan resultan $W$ dari beban terdistribusi yang ditunjang oleh sub-bagian dari kabel CD. Dengan menggambar gaya yang bersesuaian dalam segitiga, didapat hubungan berikut:

$\mathrm{T} \cos$ ? $=\mathrm{To} \mathrm{T} \sin [=\mathrm{W}$

$T$ ? ? ? $T$ ? 60

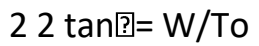


Katenari adalah suatu kabel $A B$ membawa beban terdistribusi serbasama sepanjang kabel itu sendiri (gambar 15).

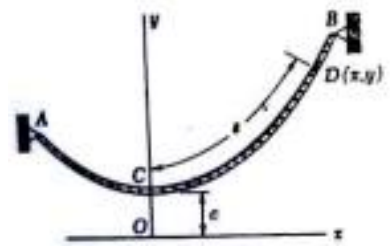

(4)

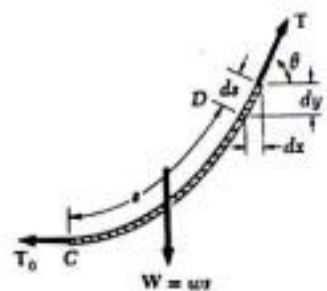

(b)

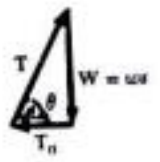

(c)

Gambar 8. 26 Model Kabel Katenari.

Beban persatuan panjang (diukur sepanjang kabel) ditandai dengan $\mathrm{w}$ dalam $\mathrm{N} / \mathrm{m}$ atau dalam $\mathrm{lb} / \mathrm{ft}$. Besar $\mathrm{W}$ dari beban total dibawa oleh sub-bagian kabel dengan panjang $S$ memanjang dari titik terendah $C$ ke titik $D$ sembarang adalah $W=$ w.s. Sehingga berlaku:

$\mathrm{T}=T$ ws 0

2 ใ?ำ 22

Untuk menyederhanakan perhitungan, dikenalkan konstanta $\mathrm{c}=$ To/w. Sehingga:

$\mathrm{To}=\mathrm{wc} W=\mathrm{Ws} T=\mathrm{w} c 2$ ? ?? $\mathrm{T} 2$

Diagram benda bebas dari sub-bagian kabel $C D$ diperlihatkan dalam gambar 15 . Namun diagram ini tidak dapat digunakan secara langsung untuk memperoleh persamaan dari kurva dibentuk oleh kabel karena tidak diketahui jarak horizontal dari $D$ ke garis aksi dari resultan beban $W$. Untuk mendapatkan persamaan tersebut, pertama-kali ditulis proyeksi 


\section{DAFTAR PUSTAKA}

Anonim, 1982, PUBI-1982. Puslitbang, Pusat Penelitian dan Pengembangan Pemukiman, Bandung. Anonim, 1990. Tata Cara Pembuatan Campuran Beton Normal, SKSNI T-15-

1990-03 Departemen Pekerjaan Umum, Yayasan LPMB, Bandung.

Anonim, DPU, Peraturan Beton Bertulang Indonesia, Jakarta.

Anonim, DPU, Peraturan Umum untuk Bahan Bangunan Indonesia, Jakarta.

Antono A., 1995. Bahan Konstruksi Teknik Sipil, Diktat Kuliah, Laboratorium BKT, Jurusan

Teknik Sipil, Fakultas Teknik, UGM.

Dipohusodo, I, 1994. Struktur Beton Bertulang, Gramedia, Jakarta. Gideon H. Kusuma, 1994. Pedoman Pengerjaan Beton, Seri 2, Penerbit Erlangga, Jakarta. Ponco,Y, 2002. Tinjauan Penggunaan Gabungan Pasangan Batu Kali Dan Beton Bertulang

Sebagai Bahan Konstruksi Penahan Lentur, Skripsi UKRIM, Yogyakarta.

Puspantoro, B, 1999. Bahan Bangunan, Diktat Kuliah, Yogyakarta.

Tjokrodimulyo, K, 1996. Teknologi Beton, Nafiri, Yogyakarta.

Tjokrodimulyo, K, 1987. Hubungan Antara Umur dan Kuat Tekan Pada Beton Dengan Bahan

Batuan Sungai Krasak. Yogyakarta.

Wahyudi, L dan Syahril, 1997. Struktur Beton Bertulang Standart Baru SNI T15-1991-03,

Gramedia, Jakarta.

ASCE, 2003, Annual Book of ASTM Standards Section 4, Philaldelphia.

Badan Standarisasi Nasional, 2002, Tata Cara Perencanaan Konstruksi Kayu Indonesia, SNI

03-1726-2002, Jakarta.

Blass, H.J., P. Aune, B.S. Choo, R. Gorlacher, D.R. Griffiths, B.O. Hilso, $P$. Raacher dan 
G. Steek, (Eds), 1995, Timber Engineering Step 1, First Edition, Centrum Hout,

The Nedherlands.

Breyer, D.E., 1988, Design of Wood Structures, Second Edition, Mc Graw-Hill, New York. Gere, J.M. dan S.P.Timoshenko, 1985, Mechanics of Materials, Second Edition, Wadsworth, Inc, California. Liese, W, 1980, Anatomy and Properties of Bamboo, In: International Bamboo Workshop,

October 6-14, 1985, Nanjing, China, pp $196-208$ 